\title{
The Impact of Taxes on Income Mobility*
}

\author{
Mario Alloza ${ }^{\dagger}$ \\ BANK OF SPAIN and CENTRE FOR MACROECONOMICS
}

October 4, 2016

\begin{abstract}
This paper investigates how taxes affect relative mobility in the income distribution in the US. Household panel data drawn from the PSID between 1967 and 1996 is employed to analyse the relationship between marginal tax rates and the probability of staying in the same income decile. Exogenous variation in marginal tax rates is identified by using counterfactual rates based on legislated changes in the tax schedule. I find that higher marginal tax rates reduce income mobility. An increase in one percentage point in marginal tax rates causes a decline of around $0.8 \%$ in the probability of changing to a different income decile. Tax reforms that reduce marginal rates by 7 percentage points are estimated to account for around a tenth of the average movements in the income distribution in a year. Additional results suggest that the effect of taxes on income mobility differs according to the level of human capital and that it is particularly significant when considering mobility at the bottom of the distribution.
\end{abstract}

Keywords: income mobility, inequality, marginal tax rate.

JEL classification: E24, E62, D31, D63, H24, H31.

${ }^{*}$ I am indebted to Morten Ravn for invaluable guidance and support and also to Raffaella Giacomini and Vincent Sterk for very helpful discussions and insightful suggestions. I also want to thank Andrew Chesher, Mariacristina De Nardi, Eric French, Valérie Lechene, Attila Lindner, Fabien Postel-Vinay and audience at UCL, University of Essex, Bank of England, Bank of Spain, CREST, Universitat Autónoma de Barcelona, Queen Mary University of London, University of Manchester, Nazarbayev University and Uppsala University for their comments and useful conversations.

†Mario Alloza: Banco de España, Calle Alcalá 48 28014, Madrid (Spain), m.alloza@bde.es. 


\section{Introduction}

The last four decades have witnessed a sustained increase in income and wealth inequality in the US, particularly at the top end of the distribution. ${ }^{1}$ This phenomenon has received substantial attention in academic research, ${ }^{2}$ policy debates as mentioned in President Obama's Economic Report (see Council of Economic Advisers (2015)), and popular opinion (e.g. protest movements such as Occupy Wall Street). As noted in Arrow and Intriligator (2015), inequality is a highly relevant normative issue, since society perceives an unequal distribution of income as an unjust outcome of market economies. However, there are other features of the income distribution beyond inequality that have welfare implications for the society and are relevant from a policy point of view. Overlooking some of these aspects may yield an incomplete or inaccurate picture of the effects of policies that address economic disparities.

This paper looks at the impact of fiscal policy on another aspect of the income distribution different to inequality. Particularly, I investigate the relationship between taxes and income mobility. While inequality reflects changes in the variance (and higher moments) of the income distribution, income mobility is the result of variations in the covariance of income between two periods of time. ${ }^{3}$ For any given level of income inequality, mobility reduces the association between the positions of origin and destination in the income distribution, increasing equality of opportunity. Therefore, to the extent that income mobility is a desirable feature of an economy, it is then relevant to consider how fiscal policy may affect it. ${ }^{4}$

I analyse the impact of taxes on the probability of moving in the income distribution in the US using data from the Panel Study of Income Dynamics (PSID). I measure income mobility as changes in the relative position of households in the income distribution (i.e. changes in deciles or quintiles) across time. Income is defined as the Adjusted Gross Income (AGI) of the household. I assess the degree of mobility across three specifications for the income distribution that consider pre-tax income, post-tax income and post-tax and post-transfer income respectively. Then, I construct the fed-

\footnotetext{
${ }^{1}$ See Piketty and Saez (2003) for long-run trends in income inequality and Saez and Zucman (2014) or Quadrini and Ríos-Rull (2015) for the case of wealth.

${ }^{2}$ Piketty (2014) provides extensive evidence of income and wealth inequality around the world while Stiglitz (2012) highlights its consequences: "the impact of inequality on societies is now increasingly well understood -higher crime, health problems, and mental illness, lower educational achievements, social cohesion and life expectancy" (inside cover).

${ }^{3}$ See Gottschalk (1997).

${ }^{4}$ Kopczuk et al. (2010) argue for the need to study income inequality and mobility jointly. Income mobility is a determinant of inequality in the long run: when there is no mobility in the income distribution, short-run inequality perpetuates.
} 
eral individual tax liabilities faced by each household in the sample using the NBER TAXSIM simulator. With these data in hand, I estimate a linear probability model to understand how changes in the marginal tax rate affect the likelihood that households are mobile in the income distribution during two adjacent years. My identification approach accounts for endogeneity in the marginal rates by isolating the variation in taxes that is only due to legislative changes. I exploit this source of exogenous variation as an instrument in the regressions.

The results obtained suggest that higher marginal tax rates reduce income mobility. Particularly, I find that an increase of one percentage point in the marginal rate is associated with declines of about $0.5-1.3 \%$ in the probability of changing deciles of income. A decrease of 7 percentage points in the marginal tax rate (slightly smaller than a standard deviation of non-zero changes in the rates) can account for about a tenth of the average income mobility in a year. The effect of taxes on mobility arises in specifications that consider income distributions both before and after taxes and transfers, suggesting that the impact of taxation on mobility goes beyond redistribution effects. The economic mechanism that induces this impact seems to be related to the labour market incentives created by changes in the tax schedule. Additional results suggest that the effect of taxation on income mobility differs according to the level of human capital (measured as the education of the head of the household) and that it is particularly significant when considering mobility at the bottom of the distribution.

The evidence that taxes have a negative impact on income mobility has important implications for the design of policies that aim to address economic disparities. While some studies have pointed out to the importance of progressive taxation in addressing inequality ${ }^{5}$ the results from this paper suggest that such changes may have a detrimental impact on income mobility. Therefore, the design of optimal fiscal policy should consider the overall impact on welfare of the trade-off that might arise when jointly addressing income inequality and mobility.

This paper relates to different strands of literature. First, it is connected to the literature that investigates the effects of tax changes on taxable income (elasticity of taxable income, or ETI), as reviewed in Saez et al. (2012). This research finds that taxable income only reacts moderately to changes in the marginal tax rate. ${ }^{6}$ Mertens (2013) suggests that accounting for empirical difficulties in the estimation of the ETI at

\footnotetext{
${ }^{5}$ See Piketty and Saez (2007) and Diamond and Saez (2011).

${ }^{6}$ Saez et al. (2012) suggest a range of estimates from 0.12 to 0.40 for the ETI. The authors argue that responses for the top-earners can be substantially higher. For example, Slemrod (1996) finds that the Tax Revenue Act of 1986 explains to a large extent the increase in reported income of the top earners.
} 
the aggregate level (such as policy endogeneity or timing) results in larger elasticities for different income groups beyond the top earners. My paper relates to some methodological aspects of this literature, ${ }^{7}$ but I focus on the effects of taxes on measures of household's mobility across the income distribution as opposed to the individual's response of reported taxable income (for this purpose I employ a different type of data, the PSID, that allows me to control for relevant demographic factors).

My paper relates to an extensive literature on income mobility surveyed in Fields and Ok (1999) and Jäntti and Jenkins (2015). ${ }^{8}$ Early works on the measurement of income mobility include Shorrocks (1978a) and Shorrocks (1978b), which lay down many of the tools currently used to measure mobility. A number of papers have investigated the degree and evolution of mobility in terms of income (broadly defined) and earnings. Hungerford (1993) uses family income data from the PSID to analyse trends in mobility, focusing on changes in the position in the income distribution between 7 year-periods in both annual and permanent income. The author compares mobility between the 1970s and 1980s to find considerable movement within the income distribution (although he finds less evidence of sizeable upward or downward movements). Also using PSID data, Gottschalk (1997) looks at earnings mobility in one-year and seventeen-year periods. The author concludes that the degree of mobility is high enough to support the view that people are not stuck at the bottom or at the top of the distribution. Kopczuk et al. (2010) employs individual data from the Social Security Administration to investigate the evolution of both short-term mobility (measured by changes in rank correlation in year-to-year earnings and in mobility indices defined over periods of 3-5 years) and longterm mobility (i.e. across the working life). More recently, Bradbury (2011) looks at various indices of income mobility using the PSID between 1969-2006 and time intervals spanning 11 years.

Although the concepts of mobility and samples used differ, these papers find a similar evolution of mobility in the US: a relatively flat profile during the 1970 s and a somewhat decreasing trend after that. I measure mobility in comparable ways to this literature, however, since my main goal is to identify the effects of tax changes, I instead

\footnotetext{
${ }^{7}$ I use variation in legislated taxes to address endogeneity following Gruber and Saez (2002).

${ }^{8}$ During this paper, I will refer to income mobility as intragenerational mobility. Jäntti and Jenkins (2015) also survey the literature on intergenerational or social mobility (the degree of association between parents and children income). There has been a recent increase in the research aiming to understand the degree of intergenerational mobility and its factors. For example, Chetty et al. (2014a) analyses the geographical differences of intergenerational mobility in the US and Chetty et al. (2014b) explores its evolution over time, which has remained fairly constant despite rising inequality. The determinants of social mobility are explored in Chetty and Hendren (2015), who investigate how neighbourhoods affect intergenerational mobility through childhood exposure effects.
} 
consider mobility across two adjacent years. ${ }^{9}$

The literature on the effect of taxes on income mobility is more limited. Lerman and Yitzhaki (1995) analyse the effects of the 1991 tax reform on the income distribution recognising two potential channels: higher taxes can reduce the income gaps between people and, in some cases, change their relative position by means of redistribution. The authors decompose the evolution of the Gini coefficient due to income changes holding the relative position constant and due to changes in the relative position holding income constant, and find that this second effect is important in understanding the redistribution effects of the the 1991 tax reform. Larrimore et al. (2015) analyse the determinants of income mobility between two-year periods using a panel of tax returns between 1999 and 2011. They compute the difference between income before and after federal taxes as a measure of the stabilising power of taxes.

In contrast to both Lerman and Yitzhaki (1995) and Larrimore et al. (2015), I analyse the effects of taxes on mobility that can also be due to changes on the pre-tax income (i.e. because of a change in the labour supply), not only due to the redistribution effect of the tax system. More substantially, my paper uses a different methodology to asses the impact of taxes on income mobility by exploiting exogenous variation in the marginal tax rates, over a relatively long panel of data that includes several tax reforms.

This paper also relates to the literature that investigates the aggregate impact of taxes such as Romer and Romer (2010) and Barro and Redlick (2011). Both studies find substantial effects of changes in taxes on economic activity. Romer and Romer (2010) estimate the impact of a tax increase of 1 percent of GDP to amount to a reduction of output by $3 \%$ over the course of three years. Barro and Redlick (2011) find that the effect of taxes on GDP act mainly through substitution effects, with increases in the average marginal tax rates significantly reducing GDP. ${ }^{10}$ Mertens and Ravn (2013) highlight the importance of distinguishing between different type of taxes, estimating large effects of taxes on output in the short run. Zidar (2015) exploits variation in US states to find aggregate effects on employment resulting from tax cuts for lower-income groups (as opposed to tax cuts for the top $10 \%$ of the income distributions, which are not found to have a large effect on employment growth).

Income and wealth inequality have been the object of extensive study in macroeco-

\footnotetext{
${ }^{9}$ Gottschalk (1997) notes that accounting for longer periods is not necessarily more appropriate than one-year periods to analyse mobility and inequality, given the fact that low-income households are more likely to face borrowing constraints over longer horizons.

${ }^{10}$ Barro and Redlick (2011) find that GDP falls 1.1 for each dollar increase in federal taxes, with one year lag.
} 
nomics. ${ }^{11}$ Piketty and Saez (2003) use a long panel of tax returns to analyse income inequality trends in the US since 1917. The authors find that income inequality, as measured by the share of income by the top decile earners, sharply decreased during World War II and started to increase from the 1970s. ${ }^{12}$ Piketty (2014) compiles extensive empirical evidence on the evolution of income and wealth inequality for the US and other countries, finding a noticeable increase in both variables. The author suggests that this increase in inequality is a feature of capitalist economies (given that the rate of return of capital is found to exceed that of economic growth) and advocates for fiscal reforms that establish a global wealth tax and a more progressive income taxation.

In order to understand the causes of wealth inequality, macroeconomic models have relaxed the assumption of a representative agent, allowing for heterogeneity in earnings and other characteristics, in the spirit of Aiyagari (1994). ${ }^{13}$ Quadrini and Ríos-Rull (2015) survey the literature on the theories used the explain the causes of inequality, and its implications for the aggregate economy. While economic models predict that wealthy households tend to dissave, this is at odds with the data. De Nardi (2015) surveys the mechanisms that have been used to explain the reasons for wealthy individuals to exhibit a high rate of savings and its implications for wealth inequality. This literature has found that differences in the degree of patience among individuals, the transmission of human capital (skills passed from parents to children) and voluntary bequests across generations or the decisions to become an entrepreneur are plausible reasons that can explain some aspects of the distribution of wealth.

The rest of the paper is organised as follows. Section 2 develops a simple framework to understand the relevant mechanisms behind the effect of taxation and income mobility. Section 3 describes how the data regarding income mobility and taxes are constructed. The empirical strategy and the main results are described in Section 4. Section 5 contains several robustness checks. Further empirical results on the heterogeneous effects of taxes on income mobility are explored in Section 6. Lastly, Section 7 concludes and discusses potential extensions.

\footnotetext{
${ }^{11}$ Aghion et al. (2015) investigate the relationship between innovativeness and both top-income inequality and social mobility.

${ }^{12}$ Building on the same dataset, Saez and Zucman (2014) capitalise income to produce a measure of wealth inequality, and find that this variable has substantially increased in the last few years.

${ }^{13}$ See Heathcote et al. (2009).
} 


\section{A Simple Theoretical Framework}

Before turning to the empirical analysis, I consider a simple model of labour supply to highlight the key determinants of the relationship between taxation and income mobility.

Consider an economy populated by two households $(i=1,2)$ with quasilinear preferences:

$$
U\left(c_{i, t}, n_{i, t}\right)=\sigma_{i} c_{i, t}-\frac{X_{i}}{1+\frac{1}{\eta_{i}}} n_{t}^{1+\frac{1}{\eta_{i}}}
$$

where $c_{i, t}$ and $n_{i, t}$ represent consumption and hours worked for household $i$ at date $t$. Preference parameters can potentially depend on each household characteristics: $\sigma_{i}$ represents the relative weight of consumption in the utility function, $X_{i}$ denotes preferences regarding labour supply (which could be determined by demographic variables, family composition, etc.) and $\eta_{i} \geq 0$ is the Frisch elasticity of labour supply (a key element in this framework).

Individuals face a budget constraint $c_{i, t}=\left(w_{i, t} n_{i, t}\right)-T\left(w_{i, t} n_{i, t}\right)$, where wages $w_{i, t}$ evolve exogenously following $w_{i, t}=w\left(1 \pm \varepsilon_{i, t}\right)$, with $\varepsilon_{i}>0$. In each period, wages are equal to $w_{1, t}=w\left(1+\varepsilon_{1, t}\right)$ for household $i=1$ and $w_{2, t}=w\left(1-\varepsilon_{2, t}\right)$ for household 2 with probability $\pi>0$. With probability $1-\pi$ wages become $w_{1, t}=w\left(1-\varepsilon_{1, t}\right)$ and $w_{2, t}=w\left(1+\varepsilon_{2, t}\right)$. The tax system is assumed to be given as:

$$
T^{\prime}\left(w_{i, t} n_{i, t}\right)= \begin{cases}\tau^{L}+\tau & \text { if }\left(w_{i, t} n_{i, t}\right) \geq(1+\varepsilon) w n_{i, t}^{H^{*}} \\ \tau^{L} & \text { if }\left(w_{i, t} n_{i, t}\right)<(1+\varepsilon) w n_{i, t}^{H^{*}}\end{cases}
$$

where $\tau^{L}$ and $\tau^{L}+\tau$ are the marginal tax rates faced by households with a low or high wage realisation, respectively. $n_{i, t}^{H^{*}}$ and $n_{i, t}^{L^{*}}$ are the labour supply functions that result from optimality in consumption-leisure decisions:

$$
\begin{aligned}
n_{i, t}^{H^{*}} & =\left(\left(1-\tau^{L}-\tau\right)(1+\varepsilon) w \frac{\sigma_{i}}{X_{i}}\right)^{\eta_{i}} \\
n_{i, t}^{L^{*}} & =\left(\left(1-\tau^{L}\right)(1-\varepsilon) w \frac{\sigma_{i}}{X_{i}}\right)^{\eta_{i}}
\end{aligned}
$$

Assuming that preferences are the same for both type of households $\left(\eta_{1}=\eta_{2}=\eta\right.$, $\left.\sigma_{1}=\sigma_{2}=\sigma, X_{1}=X_{2}=X\right)$, when $\tau=0$ the tax schedule becomes proportional and the household with a higher realisation of wages (say, $i=1$ ) is ranked first in the 
income distribution:

$$
\left(1-\tau^{L}\right)(1+\varepsilon) w n_{1, t}^{H^{*}}>\left(1-\tau^{L}\right)(1-\varepsilon) w n_{2, t}^{L^{*}}
$$

Conditional on an initial distribution of income, the relative income mobility in this economy is given by $\operatorname{Pr}\left(\right.$ move $\left.\mid w_{2, t-1}=w(1+\varepsilon)\right)=\pi$.

When $\tau$ is positive, the tax schedule is progressive and both labour-supply functions are related by:

$$
n_{i, t}^{H^{*}}=\left(\left(1-\frac{\tau}{1-\tau^{L}}\right)\left(\frac{1+\varepsilon}{1-\varepsilon}\right)\right)^{\eta} n_{i, t}^{L^{*}}
$$

In any given period, the optimal labour supply choice weights two opposing effects: (i) a higher wage $\frac{1+\varepsilon}{1-\varepsilon}$ increases the price of leisure and makes the household willing to supply more labour and (ii) a higher rate $\tau$ makes the tax system more progressive and reduces the incentives to supply more hours of work. As long as $\tau<\left(1-\tau_{t}^{L}\right) \frac{2 \varepsilon}{1+\varepsilon}$ the household will have incentives to take advantage of a higher wage draw and will optimally choose to supply more labour $n_{i, t}^{H^{*}}>n_{i, t}^{L^{*}}$. When $\tau$ is high enough, the tax schedule eliminates the incentives to work induced by a a high-wage shock. Particularly, when $\tau=\left(1-\tau_{t}^{L}\right) \frac{2 \varepsilon}{1+\varepsilon}$ the household will decide to not to increase the hours of work due to the wage shock and $n_{i, t}^{H^{*}}=n_{i, t}^{L^{*}} \cdot 14$

In the case of $\tau=\left(1-\tau_{t}^{L}\right) \frac{2 \varepsilon}{1+\varepsilon}$, both households supply the same amount of hours worked. In the presence of preference shocks $X_{i}$ that counteract the effects of the wage shocks, less progressive taxation would render the labour supply of the households more sensitive to changes in wages, resulting in higher income mobility.

This simple framework allows us to derive the following implications. First and most important, the tax system can reduce income mobility by disincentivizing labour supply. This effect arises because households take less advantage of economic opportunities when the marginal tax rate is very high. The final effect on mobility depends crucially on the Frisch elasticity of labour supply (and whether it is homogeneous across households) since this parameter governs how much the taxes distort the incentives to work. Preferences regarding consumption also matter. A wealth effect on labour supply, which is absent in this minimal framework, will make households more willing to supply work when taxes increase (although this effect will be mitigated by a progressive tax schedule). Another important factor in determining mobility is the wealth accumulation. When savings are allowed, households face an intertemporal optimisation

\footnotetext{
${ }^{14}$ When we consider $\tau_{L}=0.25$ (approximately the US average federal marginal tax rate on individual income during 1967-1996), $w=10$ and productivity shocks representing $5 \%$ of the base wage $w$, then we have that the value of $\tau$ such that $n_{i, t}^{H^{*}}=n_{i, t}^{L^{*}}$ is $\tau=0.07$, resulting in $\tau^{L}+\tau=0.32$.
} 
problem. Those households who are lucky and obtain subsequent realisations of high wages will be able to build up savings. The return obtained from these savings will increase total income, making it less likely to move down in the income distribution.

Therefore, while taxes are likely to have an effect on income mobility, the precise impact remains an empirical question. When estimating this effect, it will be important to use data that allows separating household effects (as, for example, taste for leisure) from household shocks. The PSID, given its panel nature, is an attractive dataset to address this question.

\section{$3 \quad$ Data and Trends}

The PSID (Panel Study of Income Dynamics) is an annual survey elaborated by the University of Michigan since 1968. ${ }^{15}$ It follows the same families and their split-offs over time, creating a panel structure. The survey was originally created from two samples: the Survey Research Center (SRC) or core sample (representative at the national level), and the Survey of Economic opportunity (SEO) or Census sample, which over-represents low income households. The PSID provides weights that render the combination of both samples representative of the US population while accounting for the attrition that occurs over time when families are stopped being interviewed.

I restrict the whole sample by considering main adults (the heads and their spouses) of households that are led by a male working head aged 25 to 60 who is not selfemployed. Following Aaronson and French (2009), families with a head working less than 300 or more than 4,500 hours per year, earning less than $\$ 3$ or more than $\$ 200$ per hours in 1996 prices are considered outliers and dropped from the sample. This selection criteria is based on the intention to reflect changes in the income mobility that arise as a result of labour market interaction. In Section 5, I check the robustness of the results when considering a more inclusive sample. This selection leads to a total of 5,430 (continuously married) households representing a total of 50,471 observations between 1967 and 1996. The final date of the sample is dictated by the change in the PSID frequency produced in 1997 (referring to data from 1996), when the periodicity of data releases switched from annual to biannual.

\footnotetext{
${ }^{15}$ The survey contains data from 1967, since some of the variables asked (e.g. income) refer to the previous year.
} 


\subsection{Measuring income mobility}

This section discusses issues related to income mobility measure and explores its dynamics in the US over the sample period.

Consider an ordering of income in time $t$ in $N$ different ranks (i.e. quantiles of income). Let $s_{t}^{n}$ denote the households with income belonging to rank $n \in[1, N]$. The mobility process can be represented by a vector $s_{t}=\left(s_{t}^{1}, s_{t}^{2}, \ldots, s_{t}^{N}\right)$ and a probability matrix $P$ with dimension $n \times n$ and rows adding up to 1 such that:

$$
s_{t}=P_{t} s_{t-1}
$$

The vector $s_{t-1}$ summarises the probability distribution of income in period $t-1$. The matrix $P$ characterises the mobility process by determining the probability that a household in income group $n$ at time $t-1$ remains in the same decile next period (entry $P^{n, n}$ in matrix $\mathrm{P}$ ) or transits to another decile $k \neq n .{ }^{16}$

There are different indices that can be used to measure the degree of income mobility. ${ }^{17}$ The immobility ratio (IR) summarises changes in relative positions by computing the degree of concentration along the diagonal of matrix $P$, i.e. the fraction of households that remain in the same income group during two periods of time. In the case of extreme immobility (no household changes deciles between $t$ and $t-1$ ), IR=1.

In a similar vein, the normalised trace index (NTI) proposed by Shorrocks (1978b) uses the elements in the diagonal of $P$ to measure mobility:

$$
\mathrm{NTI}=\frac{N-\operatorname{trace}(P)}{N-1}
$$

When $P$ is the identity matrix, the sum of the diagonal of matrix $P$ is equal to $N$ and the NTI becomes 0 .

Both the IR and NTI indices use information from the diagonal of matrix $P$. The Average Jump Index (Bartholomew (1973)) exploits other information in $P$ to asses the degree of mobility by counting the number of income thresholds (e.g. deciles) that a households passes through between two periods. This index is computed as the average of absolute changes in income ranks for all the sample. A value of 0 indicates perfect immobility (origin independence).

\footnotetext{
${ }^{16}$ In the special case when vector $s_{t-1}$ contains all the necessary information to predict $s_{t}$, i.e. $\operatorname{Prob}\left(s_{t} \mid s_{t-1}, s_{t-2}, \ldots, s_{t-k}\right)=\operatorname{Prob}\left(s_{t} \mid s_{t-1}\right) \forall k \geq 1$ and $t$, the process $s_{t}$ is said to be Markovian. $P$ becomes the Markov matrix and transitions along the income distribution between $k$ periods can be obtained from $s_{t+k}=s_{t} P^{k}$.

${ }^{17}$ See Fields and Ok (1999) or Jäntti and Jenkins (2015) for exhaustive reviews of the different tools available to measure income mobility.
} 
There are other measures that are not restricted to the relative position of households in the income distribution. This is the case of the Pearson correlation $(r)$, defined as:

$$
r=\operatorname{corr}\left(\log \left(i n c_{t-1}\right), \log \left(i n c_{t}\right)\right)
$$

where $i n c_{t}$ is the real level of income at time $t$. The Hart index (Hart (1976)) is a variant of this measure and is defined by $H=1-r$. When income between two periods is perfectly correlated, we have the case of complete immobility and $H=0$.

Income is constructed as the Adjusted Aggregate Income (AGI) based on the joint taxable income of the head and spouse in the household. ${ }^{18}$ Different measures of income (before taxes, after taxes, and after transfers) are used to assess mobility.

Figure 1 plots the evolution of the mobility indices described above using a pretax measure of income, setting $N=10$ (income is divided in deciles) and allowing $t$ to represent a year. While many studies in the literature focus on a longer horizon to analyse mobility (e.g. five years), I choose to use a shorter horizon to be able to identify the effect of taxation on income mobility.

The degree of co-movement between the indices of mobility is high: 1-IR and NTI have a correlation of $95 \%$. The correlation between those two indices and the measure of income ranks passed is of 90 and $88 \%$, respectively. The correlation between the Hart index and the rest of mobility measures ranges between 70 and above $80 \%$.

The evolution of these indices shows a flat profile from the end of the 1960s to the end of the 1970s, although the NTI index exhibits a slightly upward trend during this period. Mobility declines somewhat during the decade of the 80s. It increases more noticeably at the beginning of 1990s (particularly the 1-IR index), but then returns to previous levels towards the end of the sample. The comparison of this evidence with that found in the literature is difficult, since many studies focus on income mobility during a longer time horizon (see for example Hungerford (1993) and those cited in Jäntti and Jenkins (2015)). However, Gittleman and Joyce (1999) considers similar mobility indices for 1, 5 and 10-year windows between 1969 and 1990. The authors find a mild reduction in mobility during the 1970s and an upwards trends until 1990. Gottschalk (1997) reports a transition matrix across quintiles of income between 1973 and 1974 using PSID which is largely similar to my estimation of matrix $P$ in Equation 2 for those years (not shown).

While Figure 1 displays the probability of mobility overall, it is also interesting to

\footnotetext{
${ }^{18} \mathrm{~A}$ broader definition of income would include other sources within the family (e.g. children or other relatives). However this would require making assumptions on how to identify tax units within the household and limit the availability of data. Section 5 explores the robustness of the results to different definition of income.
} 
analyse whether these trends in mobility are shared across particular income ranks. Figure A1 shows the evolution of $1-P^{1,1}$ and $1-P^{N, N}$ (where $P^{k, k}$ is the $k, k$ element of matrix $P$ in Equation 2) for pre-tax and post-tax distributions of income. The probability that a household moves away from the first decile of income (Panel A) has recorded an upward trend during most of the time horizon, only to be reverted towards the end of the sample period. The evolution of the probability of not remaining in the top decile shows a pattern that resembles that of the 1-IR index commented in the previous paragraph: a downwards trend initiated after 1975 which changes direction since the beginning of the 1990s.

\subsection{Taxation in the US during the sample period}

I use the NBER's TAXSIM program to construct the federal tax liabilities faced for each household in the sample. This tax simulator recreates each year's tax law by taking into account features of the US tax code such as the Earned Income Tax Credit (EITC), the Alternative Minimum Tax (AMT) or deductions and exemption phaseouts. Since TAXSIM only computes state taxes since 1977 and due to the regressive nature of Social Security taxes (FICA), the main empirical results in Section 4 make use of a longer horizon (and additional tax reforms) by exclusively considering changes in federal taxation. The effects of including state and social security taxes are explained in Section 5.

TAXSIM computes the effective marginal tax rates by increasing taxable income by $1 \$ .{ }^{19}$ For many households in the PSID sample these tax rates are determined by the statutory tax rates associated with each income bracket. However, the effective marginal tax rate of other households will also be determined by the phase-out and other features of the tax code.

Marginal tax rates from TAXSIM are calculated based on tax year, marital status (since the sample only considers (legally) married people, I assume them to file taxes jointly), number of dependants (including those under 17 years), labour income from the head of the household and his spouse, asset income (arising from rentals, dividends or interests), taxable pensions, Social Security Income, property taxes and deductions on mortgage interests. ${ }^{20}$

Federal marginal tax rates have experienced substantial variation during the period considered (1967-1996). Figure 2 (Panel A) shows the evolution of the average marginal

\footnotetext{
${ }^{19}$ See Feenberg and Coutts (1993) for an introduction to the TAXSIM program.

${ }^{20}$ Since mortgage interests are not available in the PSID for all the time horizon, I follow Aaronson and French (2009) and assume that $80 \%$ of mortgage payments go to interest to impute this variable.
} 
tax rate for each income decile in US during 1967-1996. ${ }^{21}$ The broken line shows the average marginal tax rate for federal individual income taxes from Barro and Redlick (2011). ${ }^{22}$ Marginal tax rates show a marked increase during the 1970s, mainly as the result of high inflation that pushed households' income to higher tax brackets because of imperfect indexation of the tax schedule. This upward trend was more substantial for higher incomes: the average marginal tax rate for those in the top decile increased 22 percentage points between 1967 and 1980 (from 26.9\% up to 49\%) while the increase for the bottom three deciles ranged between 5 and 7 percentage points. This upward trend was substantially reverted during the decade of 1980s. This was the result of major reforms such as Reagan's Tax Reform Act of 1986, which lowered the top statutory rate from $50 \%$ to $28 \%$ (although the bottom tax rate increased by 4 percentage points). Some smaller tax increases occurred during the early 1990s (e.g. a tax hike to high income earners during Clinton's presidency increased the marginal tax rate of the top decile from $31.3 \%$ to almost $33 \%$ in 1994). The increase of the average marginal tax rate for the bottom decile since the end of the 1980s and even above the average marginal tax rates of other deciles is the result of the expansion of the EITC. ${ }^{23}$

Panel B in Figure 2 shows the individual federal income tax rates for the PSID households computed using the NBER calculator. ${ }^{24}$ The figure distinguishes between tax rates before and after the Reagan 1968 reform. The plot shows the noticeable transformation of the tax code following the Tax Reform Act of 1986, which substantially simplified the US tax code.

The high variation of taxes over time and across individuals depicted in Figure 2 supports the identification of the causal impact of tax reforms on income mobility.

\subsection{The relationship between taxation and Income mobility}

This subsections explores the relationship between income mobility and taxation at the aggregate level. The correlation between the indices of mobility 1-IR and NTI (described in Section 3.1) and the AMTR from Barro and Redlick (2011) ranges between

\footnotetext{
${ }^{21}$ See Figure A2 for the evolution of the average tax rate during the same period.

${ }^{22}$ Barro and Redlick (2011) uses data from a random sample on actual tax files and computes the average marginal tax rate with TAXSIM.

${ }^{23}$ Note that while alterations of the EITC and other provisions have increased the average marginal rate of the bottom deciles, the tax pressure of this group (as measured by the average tax rate shown in Figure A2) has lowered since 1986.

${ }^{24}$ The PSID provided an estimation of the marginal tax rate on federal income during 1976-1991 based on question in the survey regarding exemptions, filling status, etc. The correlation with my marginal tax rate computed through TAXSIM is above 90\%. Butrica and Burkhauser (1997) explore the differences between the PSID simulations and TAXSIM.
} 
35-45\%. However, the evolution of the AMTR is not exclusively restricted to taxes in legislation, but also the result of macroeconomic developments (e.g. inflation increasing the taxable income of households and pushing them to higher tax brackets).

In order to isolate changes in the US tax code from macroeconomic developments, I use the measure of legislated tax changes developed by Romer and Romer (2010). The authors produce a narrative series of changes in federal tax revenues (as a percentage of GDP) by documenting legislated tax changes in the postwar US. Table A1 shows the correlation between the mobility indices mentioned in Section 3.1 and the Romer and Romer (2010) measure of legislated tax changes $\left(\tau^{\text {Romer }}\right)$. The relationship between tax changes and mobility appears to be negative, albeit small. An OLS regression of the percentage of households changing deciles (of net income) on the narrative series $\tau^{\text {Romer }}$ yields a slope coefficient of 0.0159 (robust standard error of 0.0064 ), suggesting that legislated tax changes that increase tax revenues by $1 \%$ of GDP reduces the percentage of households changing deciles by about $1.6 \% .^{25}$

The correlations from Table A1 should not be given a causal interpretation. Legislated changes in the tax code are sometimes the result of contemporaneous economic developments, what could result in a problem of endogeneity when using aggregate data. In this context, the observed negative correlation between mobility and taxes would be the result of the state of the economy, as opposed to the disincentives produced by the tax system.

To further explore the relationship between income mobility and taxes and the direction of causality, I consider an alternative measure to $\tau^{\text {Romer }}$ that only includes tax changes not motivated by economic developments. Romer and Romer (2010) produce such narrative by exploring the motivation behind each tax change and classifying them as endogenous (motivated by economic meanings) or exogenous (motivated by ideology or other concerns uncorrelated to the current state of the economy). Mertens and Ravn (2013) and Mertens (2013) further refine this series by considering only those exogenous tax changes that affect employment taxes or individual income that became effective within one year of their legislation. ${ }^{26}$

Figure 3 plots the relationship between some relevant indices of mobility based on net

\footnotetext{
${ }^{25}$ The effect of $\tau^{\text {Romer }}$ on other measures of mobility as described in Section 3.1 ranges between 0.0242 and -0.0073 depending on the index considered, the definition of income, and number of income ranks (deciles or quantiles). However, some of these coefficients are estimated with high standard errors.

${ }^{26}$ This last criterion accounts for the effect of anticipation (i.e. the case where the econometrician has less information than the economic agents). See Mertens and Ravn (2011) and Mertens and Ravn (2012) for an analysis and evidence on the effects of anticipation in taxes, and Ramey (2011) for the case of anticipation in government spending.
} 
income (1-IR, NTI and the number of income thresholds passed) and the two narrative measures of exogenous legislated tax changes $\left(\tau^{e x o-T O T}\right.$ and $\left.\tau^{\text {exo-PI}}\right)$ described in the previous paragraph. Large tax cuts seem to be associated with higher values of the mobility indices (more relevant when considering the measure based on unanticipated personal income tax changes, $\left.\tau^{e x o-P I}\right)$. Correlations between these two variables range from $-11 \%$ to $-35 \%$. However, the limited number of tax changes meeting the above criteria makes it difficult to obtain conclusive results from this preliminary analysis. The next section analyses further this question by exploiting the disaggregated information contained in the PSID data.

\section{Empirical Analysis}

\subsection{Estimation Strategy}

The objective of this section is to quantify the effect of taxation on income mobility. To estimate this effect I regress the marginal tax rate on measures of mobility that vary on the definition of income and the number of ranks used to divide the income distribution. I estimate the following regression:

$$
\text { mobility }_{i, t}=A+B_{i}+B_{t}+\beta \tau_{i, t}+\gamma X_{i, t}+\varepsilon_{i, t}
$$

where mobility $_{i, t} \in\{0,1\}$ is a binary variable that takes value 1 when a household changes to a different income rank between periods $t-1$ and $t . B_{i}$ represents individual fixed effects that are assumed to remain constant over time. $B_{t}$ represents time fixed effects which can have an influence on the dependent variable at the aggregate level (e.g. a macroeconomic shock affecting income mobility). $\tau_{i, t}$ is the marginal tax rate of individual $i$ in time $t$ computed using TAXSIM as explained in Section 3. Individualspecific shocks to income mobility in period $t$ are denoted by $\varepsilon_{i, t}$.

The impact of taxes on income mobility can be affected by different factors. Lifecycle considerations are important since the decisions that determine income mobility (labour income or asset income) can be different for younger or older households. Preferences towards leisure can also vary over time, depending on the family composition. ${ }^{27}$ Additionally, health-related factors can potentially affect labour income and therefore,

\footnotetext{
${ }^{27}$ Labour supplied by the spouse is an important factor to take into account in this analysis since married female workers have a more disperse distribution of hours worked and are, therefore, more likely to be able to adjust their workload. See Blundell et al. (1998) for an investigation on the effects of tax reforms on female labour supply.
} 
mobility. ${ }^{28}$ To account for all these factors, vector $X_{i, t}$ in equation 3 includes the age of the head and wife, the size of family, number of children below 18 in the household, a dummy for a working spouse and a dummy for the health status of the head as control variables.

I will consider specifications where the dependent variable mobility ${ }_{i, t}$ differs in how income is measured: income before federal taxes, income after federal taxes but before transfers, and income after taxes and transfers. ${ }^{29}$ In this way, we will be able to distinguish whether the potential impact of taxes on income mobility is restricted to the redistributive effect of the tax and transfer system or has a more fundamental reason such as affecting the labour supply choices (as described in Section 2). I will also consider specifications where the dependent variable mobility $_{i, t}$ differs on how ranks of the income distribution are defined, distinguishing between deciles and quintiles in order to further support the robustness of the results.

\subsection{Results from OLS regressions}

Table 1 shows the results of estimating Equation 3 using OLS. The effect of the marginal rate on the probability that the household moves to a different decile of pre-tax income is negative and highly significant: the point estimate is -0.383 (standard error of 0.06). ${ }^{30}$ The results are robust to the inclusion of control variables regarding life-cycle, demographics, spouse labour supply or health status.

Table 2 explores the effects of taxation on alternative measures of income and income ranks. Columns 1-3 report the impact on the probability of changing deciles of income before taxes and transfers, income after taxes and before transfers, and income after taxes and transfers, respectively. Columns 4-6 use the same measures of income but consider instead the effects on the probability of changing quintiles of income. The estimated coefficient of the marginal tax rate is significant above the $99 \%$ level for all six specifications. The size of the effect is about $-0.40 /-0.35$ for most regressions, with the specification that considers changes in quantiles of post-transfer income reporting a slightly smaller estimate $(-0.285)$. Overall, these result suggest that there is negative

\footnotetext{
${ }^{28}$ See French (2005) for an investigation on how health affects labour supply and retirement decisions.

${ }^{29}$ Transfers include both non-taxable public income (e.g. Supplemental Security Income (SSI) benefits) and income transferred from other sources (e.g. relative). During the period considered, the PSID does not offer exact information on public transfers alone (SSI is reported, but others are not) with yearly frequency. However, the percentage of non-public income in the transfers variable considered here was only about $0.4 \%$ in 1980 , on average.

${ }^{30}$ Throughout this paper, models that estimate a binary outcome report estimates that can be interpreted as percentage changes in probability. For example, an estimate of -0.383 represents a $-0.383 \%$ reduction of success of the dependent variable.
} 
relationship between taxes and income mobility.

\subsection{Results from IV regressions}

The US tax code is progressive and the marginal tax rate depends therefore on income. This causes $\tau_{i, t}$ in Equation 3 to be endogenous: when a shock $\varepsilon_{i, t}$ affects income positively, the household will be pushed to a higher tax bracket, and rendering the OLS estimation of Equation 3 biased. In principle, the direction of the endogeneity bias is not clear since it depends on how a shock to $\varepsilon_{i, t}$ affects $\tau_{i, t}$. Consider the case of a positive individual shock (e.g. a time varying preference shock) that raises income and, as result of it, mobility. Since the individual will face a higher tax bracket, the relationship between the shock and $\tau_{i, t}$ is positive, making the OLS upward biased. In the opposite case, a shock that decreases income (but still increases mobility) reduces the tax bracket, inducing a downward bias in the OLS estimations. If we consider that positive shocks to $\varepsilon_{i, t}$ are more likely to drive income up (because households have more margin to increase hours worked and income in the face of positive preference shocks as opposed to shocks that make them willing to cut hours and income), then the first effect dominates, and the correlation between $\varepsilon_{i, t}$ and $\tau_{i, t}$ is positive, making the OLS estimates biased towards positive values.

To address this problem of endogeneity, I construct an instrument that isolates the variation in $\tau_{i, t}$ that is only due to changes in the tax reforms. ${ }^{31}$ The instrument is defined as:

$$
\Delta \tau_{i, t}^{t-1}=\tau_{i, t}^{t}-\tau_{i, t}^{t-1}
$$

where $\tau_{i, t}^{t}$ is the actual tax rate faced by household $i$, with income earned in time $t$ and employing the tax code for fiscal year $t . \tau_{i, t}^{t-1}$ is the counterfactual tax rate that a household $i$ with current income from time $t$ would have faced had the tax schedule from time $t-1$ remained present. Both the actual and the counterfactual tax rates are computed using TAXSIM as described in Section 3. When $\Delta \tau_{i, t}^{t-1}$ is positive, a household faces a higher tax pressure as a result of a fiscal reform. Conversely, negative values of $\Delta \tau_{i, t}^{t-1}$ indicates that tax reforms relevant for household $i$ have resulted in lower tax pressure.

Panel A of Figure 4 shows the average of $\Delta \tau_{i, t}^{t-1}$ for each income decile. The figure illustrates the extent to which new tax legislation has affected federal income liabilities.

\footnotetext{
${ }^{31}$ This strategy has been also employed in the income elasticity literature: see Gruber and Saez (2002) for an example and Saez et al. (2012) for a review of this literature and its identification approaches.
} 
As mentioned in Section 3, the US has experienced several tax reforms during 19671996. These reforms feature prominently in Figure 4, showing significant variation over time and across income deciles. These are the cases of, for example the generalised decrease in statutory tax rates of the Tax Reform Act of 1986, or the increase in the rate schedule of high income households as a result of the Omnibus Budget Reconciliation Act of 1993. Panel B of Figure 4 shows the percentage of people in the sample that are affected by tax reforms (i.e. those with $\Delta \tau_{i, t}^{t-1} \neq 0$ ). The figure shows that while some reforms affected most of households (the case of tax legislation during 1980-1989), some tax legislations only targeted low income earners (between 1974-1978), while others were focused on richer households (the case of Omnibus Budget Reconciliation Act of 1993). ${ }^{32}$

Table 3 shows the results of estimating Equation 3 using tax reforms as an instrument for the marginal tax rate. ${ }^{33}$ The estimated coefficients of the marginal tax rates are almost double the size compared to the OLS estimators, suggesting that the latter suffer from an upward bias. The probability of changing to a different decile of income when the tax rate goes up by one percentage point is estimated to be reduced by about 0.8 percentage points (columns $1-3$ in Table 3 ): -0.813 when using a pre-tax measure of income or -0.769 when considering income after federal taxes, with a standard error of 0.23 .

The effect of taxes on mobility when using a distribution of income ordered in quintiles is also negative, although slightly smaller in magnitude (but bigger in absolute value than the equivalent OLS estimates). The probability that households' income remains in the same quintile after an increase of one percentage point in the marginal tax rate is estimated to be around $0.5 \%$ (columns 4-6 in Table 3), significant at levels of confidence of $95 \%$.

To understand the magnitude of this effect, consider a reduction in the marginal rate of 7 percentage points, which is slightly smaller than the standard deviation of non-zero changes in the actual tax rate $\tau_{i, t}$. The probability that a household moves to a different decile in the income distribution increases by about 5.4-5.7\% (depending on the definition of income). Or, in other words, a 7 percentage point cut in the marginal rate makes the household about $5.5 \%$ less likely to remain in the same income decile.

\footnotetext{
${ }^{32} \mathrm{~A}$ systematic correlation between income and changes in tax legislation would threat the validity of $\Delta \tau_{i, t}^{t-1}$ as an exogenous instrument. Including a long panel where tax reforms are the result of different ideological positions mitigates this problem. Section 5 checks the robustness of the results to including lag income (see Gruber and Saez (2002) for a discussion).

${ }^{33}$ The F-statistic from the first-stage regressions shows a a very high value above 1500 for all the specifications, indicating that the instrument is relevant. Some specifications reduce considerably this value, although it always remains well above 10.
} 
This represents a tenth of the average likelihood of moving to a different income decile within one year. ${ }^{34}$

The magnitudes are remarkably similar when considering movements across quintiles of income. A 7 percentage point decrease in the marginal rate results in households being around 3.5\% more likely to move to a different income quintile. As before, this also represents a tenth of the average probability of movement in the income quintile distribution over the course of a year.

\subsection{Average and marginal tax rates}

Tax reforms can impact on effective marginal rates directly through changes in the statutory tax rates or by introducing provisions that affect deductions, tax credits or coverage. Therefore, while some changes in the US tax code have an effect through the marginal tax rates, others reduce the tax liabilities and affect the average tax rate.

In this subsection I try to isolate the effects of changes in marginal tax rates $\tau_{i, t}$ and average marginal tax rates $\bar{\tau}_{i, t}$, by exploiting variation over time and across individuals in average and marginal tax rates. I estimate a version of Equation 3 that includes the average tax rate $\bar{\tau}_{i, t} \cdot{ }^{35} \mathrm{I}$ construct an instrument in the same fashion as in Equation 4: I compute the difference between the actual average tax rate in time $t$ and a counterfactual average tax rate based on income obtained in time $t$ taxed using the code of year $t-1$. Figure A3 shows the evolution in time and across income deciles of this new instrument.

Table 4 displays the results of estimating the impact of marginal tax rates and average tax rates on different income mobility variables. The inclusion of the average tax rate and the use of the new instrument mentioned in the previous paragraph, increase the estimated coefficients on the marginal tax rate. The effect of a percentage point reduction in marginal tax rates fosters relative income mobility across deciles (of pre-tax and post-tax income, columns 1 and 2 in Table 4) by about $1 \%$ (with a standard errors of 0.18). Similarly, households are about $6 \%$ more likely to stay in the same quintile of income when the marginal tax rates goes up by one percentage point (columns 4-6 in Table 4).

While the coefficient on marginal tax rate is significant at confidence levels above 99\% across all specifications, that of the average marginal tax rate is not. The reported

\footnotetext{
${ }^{34}$ The average probability of changing deciles between two years is $55 \%$ for the pre-tax and post-tax definitions of income, and $57 \%$ for income post-transfers. The average likelihood of changing quintiles of income is smaller: $35 \%$ for pre-tax and post-tax income and $36 \%$ for post-transfer income.

${ }^{35}$ Average tax rates are constructed by dividing federal income liabilities by income. Figure A2 plot the evolution of these tax rates in the US between 1967 and 1996, averaged across income deciles.
} 
coefficients are high and negative, ${ }^{36}$ but none of them are significant at usual significance levels. Therefore, when both marginal and average tax rates are accounted for, only the former has a significant (and negative) effect on the relative mobility.

This evidence suggests that the economic mechanism that determines the effect of taxes on income mobility is based on incentives (the substitution of leisure by labour as shown in Section 2) as opposed to the wealth effects originated by a reduction in available income. This view is consistent with Barro and Redlick (2011) and Mertens (2013), who use time series evidence to analyse the impact of tax reforms. This finding has important implications for the design of fiscal policy since reforms that provide more incentives to work are more likely to foster income mobility as opposed to those that only reduce tax pressure without affecting the marginal tax rate. ${ }^{37}$

\section{$5 \quad$ Robustness}

This section checks the robustness of previous results along several dimensions. Particularly, I depart from the benchmark estimations by considering alternative definitions of distribution of income, adding further controls the regressions, including state and payroll taxes, checking the stability of the results to samples that differ in time horizon and selection criteria, employing and alternative measure to asses mobility and considering specification with different lags of the explanatory variables. The results from this section contribute to support the evidence of the negative effect of taxes on income mobility.

Alternative definitions of income. The results in Section 4 are based on measures of income defined as Adjusted Gross Income (AGI) before taxes, after taxes but before transfers and after taxes and transfers. Tables 5 and 6 report IV estimates of Equation 3 using alternative definitions of income to determine the probability of moving to different ranks. Columns 1 and 2 in Table 5 report the estimated effect of marginal tax rates on mobility across deciles of pre-taxes and post-taxes of joint taxable income of head and wife. The coefficients are slightly higher than those in Table 3, with IV estimates close to -1 (and standard errors slightly above 0.2) and highly significant.

Columns 3 and 4 of Table 5 display the effects on income mobility based on labour

\footnotetext{
${ }^{36}$ With the exception of the specification in column 3 (using deciles of post-transfers income), where the estimated coefficient is close to zero but slightly positive.

${ }^{37}$ As an additional exercise to further support this claim, one could consider episodes of tax reforms that did not affect marginal tax rates but reduced tax liabilities. These episodes are however very scarce and usually much smaller in size, therefore I do not pursue this avenue.
} 
income of the head and wife. The point estimation when using pre-tax income is slightly below -1 (-1.06, with standard error of 0.24$)$ while it is somewhat smaller when considering post-tax income (-0.74, with standard error of 0.24$)$. Both estimates are significant at confidence levels of $99 \%{ }^{38}$

Column 5 of Table 5 report the results when only asset income of the head and wife is used to determine income mobility. The point estimate is, as expected, smaller $(-0.402)$ but significant at levels of $90 \%$. Column 6 considers a broader definition of income that includes other sources of income from other people living in the family. ${ }^{39}$ The point estimation is also smaller $(-0.472)$ but significant as well.

Table 6 reports the same specifications using the alternative measures of income, but determining mobility in terms of quintiles of income. Results using the taxable income and labour income of head and wife (columns 1-4) are highly significant at levels of $99 \%$. The magnitude of the effects when considering taxable income is about -0.63 and 0.72 (for post-tax and pre-tax income respectively, with standard errors of 0.23 ), and higher when considering labour income (-1.03 for pre-tax income and -0.88 for posttax income, with same standard errors). The estimated coefficients when considering asset income or (adjusted) family income (columns 5 and 6 of Table 6 respectively) are negative but small and not significant.

Further controls. The benchmark estimates control for a number of life cycle and demographic factors. Section 2 pointed out that accumulated wealth could reduce mobility since households with higher asset income are less likely to move down the income distribution when labour income is lower. Since information on wealth is not measured frequently in the PSID during the period considered, ${ }^{40} \mathrm{I}$ use net home equity (self-reported house value minus the remaining mortgage on the house) to proxy for net worth. ${ }^{41}$ Columns 1-3 in Table 7 report the IV estimates of the marginal tax rate on income mobility when including wealth as a control. The coefficient of this variable (measured in thousands of 1996 dollars) is negative as expected: an increase of 100,000 in house equity increases the probability of staying in the same income decile by about $5 \%$. The estimated coefficient of the marginal tax rate is close to -0.8 for all three

\footnotetext{
${ }^{38}$ Interestingly, the estimated coefficient on the dummy variable for working wife in the household become larger and more significant than in other specifications.

${ }^{39}$ This measure of income is divided by the square root of the number of people living in the family to adjust it for family size. See Jäntti and Jenkins (2015).

${ }^{40}$ PSID data only includes snapshots of wealth for years 1984, 1989 and 1994, and since 1999 onwards.

${ }^{41}$ Information on household equity is included yearly in the PSID, with the exception of years 1973 and 1974. Fairlie and Krashinsky (2012) reports that net home equity represents $60 \%$ of the average homeowner wealth (64\% for the median homeowner).
} 
specifications considered (which vary in how income is measured) and remains highly significant (at levels of $99 \%$ ).

Next, I consider dummy variables of the position in the income distribution in year $t-1$ as controls. This aims to take into account two potential issues. First, the previous position in the income distribution can be informative of the likelihood of moving to other income rank. And second, related to the previous point, people positioned in the first or last income rank (e.g. the 1st and 10th decile) are, by definition, less likely to move (since their movements are restricted to one direction). Columns 4-6 of in Table 7 shows the results of including these new controls. The new variables have large and positive estimated coefficients, ${ }^{42}$ which seem to suggest that households with income belonging to the central part of the distribution (deciles 4-7) are more likely to experience movements along the income ranks. Regarding the estimated coefficients on the marginal tax rates, controlling for the previous position in the income distribution reduces the impact of marginal tax rates slightly (by about 0.1 percentage points), but the coefficients remain significant at confidence levels of $99 \%$.

As discussed in Section 4, a systematic relation between the instrument $\Delta \tau_{i, t}^{t-1}$ and previous income levels can lead to biased estimations if the error term $\varepsilon_{i, t}$ in Equation 3 also depends on previous income. To address this issue, columns 1-3 in Table 8 report the effect of marginal tax rates on the probability of income mobility when controlling for previous income (measured by AGI). The inclusion of the variable supports the validity of the instrument while also controls for non-labour income (e.g. asset income). The estimated coefficients are not noticeably changed with respect to the main results (see Table 3), and remain in the region of -0.8 (standard errors of 0.22 ) and statistically significant at levels of confidence of $99 \%$.

Lastly, columns 4-6 in Table 8 include absolute changes in income (AGI) as an additional control. By definition of the mobility variables (which capture the probability that income in period $t$ belongs to a different income rank than that of period $t-1$ ), this variable explain most of the likelihood of relative income movements. The inclusion of this variable strengthens the effect of marginal tax rate on income mobility by about 0.2 percentage points: the estimated coefficients become close to -1 (with standard errors of 0.22 ), while remaining significant.

State and Payroll tax rates. So far, only federal income tax liabilities have been considered in the analysis. However, the total effective tax pressure in the US also

\footnotetext{
${ }^{42}$ This specification highlights a common problem with linear probability models: the sum of the estimated coefficients can be in excess of 100 , which is not conceptually possible.
} 
includes payroll tax liabilities (FICA) and state-level tax liabilities. Payroll taxes are charged at the federal level to both employees and employers in order to fund social benefits programs (Social Security and Medicare). The FICA marginal tax rate has been relatively low until 1979 with substantially less variation than federal income taxes. ${ }^{43}$ On the other hand, TAXSIM can only compute marginal tax rates at the state level from 1977.

To check the robustness of the results to the inclusion of payroll and state tax liabilities, I compute the marginal and average tax rate on total tax liabilities (federal income, FICA and sate) from 1978 to 1996 using TAXSIM. ${ }^{44}$ The number of available observations in the PSID sample is reduced by about a third, down to about 35,400. Table 9 shows the estimated coefficients of the marginal tax rate on the probability of changing deciles (columns 1-3) and quintiles (columns 4-6) of income. The estimated coefficients are lower by about 0.25 percentage points when compared to those in Table 3, but still significant across all specifications considered at confidence levels of at least $90 \%$. When considering pretax income, household are $0.565 \%$ (standard error of 0.20) less likely to move to a different income decile when the marginal tax rate goes up by one percentage point. Specifications considering transition across income quantiles report estimated coefficients ranging from -0.38 to -0.33 (with standard errors of 0.19 and 0.20$)$.

Sample stability. The Tax Reform Act of 1986 had a substantial impact on the US tax code in many different dimensions (e.g. significant cuts in statutory tax rates, elimination of several provisions). To account for potential sample instability in the estimations due to this major reform, Table 10 reports the coefficients of marginal tax rates and average tax rates on the probability of moving to a different decile of income considering a sample before 1986 (columns 1-3) and from 1986 onwards (columns 46). The differences in the coefficients before and after are not statistically different from each other (probably because of the higher standard errors resulting from lower sample size). For example, the estimated coefficient of the marginal tax rate is -0.835 (standard error of 0.41) considering pre-tax income before 1986, and -1.018 (standard error of 0.26$)$ after 1986. All the estimated coefficients are statistically significantly different from 0 at confidence levels of $99 \%$.

The estimated coefficients do however show differences between before and after

\footnotetext{
${ }^{43}$ FICA marginal tax rate has averaged $0.03 \%$ between 1967 and 1978 . Its standard deviation between 1967-1996 is half of the federal income tax rates, and about a third of it during 1967-1997. See Barro and Redlick (2011).

${ }^{44}$ Figure A4 plots the variation across individuals in total marginal tax rates during this period.
} 
1986. While the coefficients are always negative, they are not significant after 1986 (in line with the results from Table 4) and significant across some specifications (using pre-tax and post-tax income) before 1986. This could suggest that the effect of average tax rates diminishes when taxes and, most noticeably, transfers are introduced (before 1986). However, a counterfactual analysis of tax reforms would be required to add support to this interpretation.

Sample selection. The PSID sample selected for this paper responds to the goal of targeting households that are actively involved in the labour market. I now check whether the results presented in Section 4 are robust to different sample specifications.

As described in Section 3, PSID includes two subsamples: a US-representative sample (core or SRC sample) and a sub-sample that over-represents low-income (the Survey of Economic Opportunity, SEO, a project from which PSID was originated). To insure representability, the PSID provides weights to account for different sampling probabilities and attrition. Columns 1 and 2 of Table 11 presents results when only the core sample (and no weights) are used. This represents a reduction of almost $40 \%$ in the sample size. However, the estimated effect of marginal tax rates on the probability of changing income deciles is still negative and highly significant at 99\%: point estimates of -0.95 and -0.72 (standard errors of 0.25 ) when considering pre-tax and post-tax income respectively.

Columns 3 and 4 of Table 11 display the estimations based on a sample that additionally includes households with a head younger than 25 or older than 60 years. ${ }^{45}$ The estimated coefficients of the marginal tax rates are smaller (but still significant at confidence levels of $90 \%$ ), suggesting that the income mobility of very young or old households is not as much determined by changes in taxation compared to households with a head aged 25-60.

Next, I consider whether the benchmark sample criteria may induce a bias due to households being self selected into groups. These would be the case if higher taxes affect the decision of work at the extensive margin (a head of household decides to become unemployed when taxes go up) or to become self-employed. ${ }^{46}$ To address this, columns 3 and 4 of Table 11 report the estimates when the sample is extended to include households with a self-employed status. The point estimates of the effect of marginal tax rates remain similar (and highly significant) to the benchmark estimations: -0.88

\footnotetext{
${ }^{45}$ These thresholds are often considered to determine the prime age for labour market engagement. See for example Keane (2011).

${ }^{46}$ The potential effect of taxes on the probability of becoming an entrepreneur is further discussed in Section 7.
} 
(standard error of 0.20 ) and -0.84 (standard error of 0.21 ) when considering pre-tax and post-tax income, respectively.

Alternatively, columns 5 and 6 display the estimates when the sample also includes households whose head is unemployed. ${ }^{47}$ Marginal tax rates are estimated to reduce income mobility by 0.72 and $0.74 \%$ (for pre-tax and post-tax income, respectively; standard errors of 0.22 ). These coefficients are statistically significant at confidence levels of $99 \%$.

Lastly, I extend the sample to include families whose head is a female. ${ }^{48}$ Columns 9 and 11 show the estimates when considering this enlarged sample (these include a dummy variable for male heads). The estimated coefficients are quantitatively similar to the benchmark results, and marginal taxes are found to increase the probability of households remaining in the same pre-tax income decile by about $0.6 \%(0.8 \%$ for post-tax income, standard errors of 0.23 and 0.24 , respectively).

Alternative dependent variable. The dependent variable mobility $y_{i, t}$ used in the main results exploits the information in the diagonal of the probability matrix $P$ in Equation 2: it computes the probability that a household with income belonging to rank $k$ in period $t-1$ remains in the same position in time $t$. An alternative way to measure mobility is to calculate the number of income ranks that a household crosses when moving in the income distribution. For example, this new variable, jump $p_{i, t}$, takes value of 3 if a household moves in the income distribution from income decile $k$ in time $t-1$ to income rank $k+3$ or $k-3$ in period $t$. Hence, this allows to analyse mobility by effectively using information in the rest of the cells in matrix $P$ apart from those in its diagonal. ${ }^{49}$

Table 12 reproduces the main results of Table 3 but switching the dependent variable mobility $_{i, t}$ by the newly created measure of mobility jump $_{i, t} \cdot{ }^{50} \mathrm{~A}$ cut in the marginal tax rate of 1 percentage point increases the average number of income deciles that a household would cross while moving in the pre-tax income distribution by 0.013 (standard error of 0.001, column 1 of Table 12). The estimated coefficient when considering a post-tax income distribution is very similar (point estimate of -0.012 , standard er-

\footnotetext{
${ }^{47} \mathrm{~A}$ dummy for heads who are employed is added to these specifications.

${ }^{48}$ PSID usually assigns the role of the head of the household to a male when he is present. But in some, occasions this role corresponds to the wife (e.g. when the female prefers to be designated as the head).

${ }^{49}$ The average of variable $j u m p_{i, t}$ in the sample is 0.89 . The average number of income ranks crossed by those who move in the income distribution is 1.61 .

${ }^{50}$ Estimations in Table 12 also include the average tax rate as an explanatory variable. The estimated coefficients on the marginal tax rates remain quantitatively the same when average tax rate is not included, but are estimated with higher standard errors, reducing their statistical significance.
} 
ror of 0.01 , column 2) and slightly smaller (point estimate of -0.008 , column 3) when considering a post-transfers income distribution.

Results are, as expected, reduced by half when the number of ranks are lowered from 10 (deciles) to 5 (quintiles). Columns 4-6 of Table 12 report these results, with point estimates between -0.005 and -0.006 depending on the measure of income considered. All the coefficients of the marginal tax rates on Table 12 are significant at confidence levels of $95 \%$.

Dynamic specifications. Following the model described in Section 2, the effect of taxation on the probability of income mobility is determined in the labour market, which is the result of a static optimisation problem. There are however reasons for believing the idea that this effect could have some dynamic structure. For example, decisions on changes in asset income as a result of variation in taxes may take more than a period to take effect (since wealth accumulation is the result of an inter-temporal problem).

To account for these effects, I estimate versions of Equation 3 that differ in the dynamic effect of the marginal tax rate $\tau_{i, t}$ on the probability of income mobility. Table 13 (columns 1 and 2) reports the estimated coefficients of the marginal tax rate when its effect is assumed to be lagged one period. The point estimates $(-0.57$ and -0.41 for pretax and post-tax income specifications; standard errors of 0.24) are smaller although still significantly different from zero (at levels of confidence of 90 and 95\%). When the tax rate is lagged two periods (columns 3 and 4), the effect is positive but insignificant when considering pre-tax income, and positive and only marginally significant when considering post-tax income. ${ }^{51}$ Further lags of the tax rate results on negative but insignificant coefficients: columns 5 and 6 report the estimates for $\tau_{t-3}$. Lags beyond 3 remain negative but are usually insignificant (not reported). These results suggest that the effect of taxes on income mobility is most noticeable on impact and during the following year. I do not find significant evidence on the effect of tax reforms on income mobility beyond that time.

Table 13 replicates the robustness check described in the previous paragraph but considering mobility across income quintiles. As with the case of deciles, the estimated coefficients on the lagged marginal tax rate are negative and significant (above 95\%), but slightly higher: -0.79 and -0.53 (with standard errors of 0.23 and 0.24 ) for the specifications of pre-tax and post-tax income. Lagging the marginal rate further, results in

\footnotetext{
${ }^{51}$ This is the only specification where the effect of $\tau_{i, t-2}$ is both positive and significant. Specifications when considering income quintiles (see Table14), post-transfer income (not reported) or further controls (not reported) do not find this coefficient to be significant.
} 
estimated coefficients not statistically different from 0 (in the case of a two-period lag, the coefficients are positive and insignificant, but become negative -and still insignificant, for long horizons).

\section{Additional Evidence on Taxation and Mobility}

\subsection{The heterogenous effects of taxes}

This subsection analyses how different are the effects of changes in marginal taxation on income mobility across different levels of education. The degree of education can be a proxy for labour market skills. It is therefore interesting to analyse the income mobility dynamics for two sub-samples: households led by a head that has completed college education and households whose head has a level of education below college graduate.

I now re-estimate Equation 3 with different dependent variables. First, I create a binary variable to describe upward movements in the income distribution, $u p_{i, t}$, taking value 1 when the income of a households move up to a higher income rank. Similarly, I create a variable that considers downward movements in the income distribution, down $_{i, t}$ (with value of 1 when income rank moves to a lower position). For comparison I also define a variable determining immobility as stay $_{i, t}=1-$ mobility $_{i, t}$.

Table 15 shows the estimated coefficients of the marginal tax rates in the income mobility variables described in the previous paragraph for the sample of non-college households. ${ }^{52}$ It is worth noting that, for this sample of non-college graduates, the spouse's participation in the labour market is an important determinant of income mobility: a working spouse increases the likelihood of moving up by about $17 \%$ (columns 1 and 2, standard error of 1.09), while it reduces the probability of moving down by about $18 \%$ (columns 5 and 6 , standard error of 1.44). A one percentage point increase in the marginal tax rate increases the probability of moving down to lower deciles of income by about $1 \%$ (columns 5 and 6 , standard error of 0.4 ) and increases the likelihood of moving up in the income distribution to a higher extent, by around $1.5 \%$ (columns 1 and 2, standard errors of 0.27 ). Consistently with the results of Table 3 ,

\footnotetext{
${ }^{52}$ The estimated coefficients for the mobility variables are related by $\beta^{\text {move }}=\beta^{\text {up }}+\beta^{\text {down }}$, where $\beta^{\text {move }}=-\beta^{\text {stay }}$. In the regressions shown in Tables 15 and 15 we have that $\beta^{\text {up }}+\beta^{\text {stay }}+\beta^{\text {down }}$ is not usually 0 . This is due to differences in the samples used: specifications for variable $u p_{i, t}$ (columns 1 and 2 ) exclude households with an income in time $t-1$ belonging to the 10 th decile, while specifications for variable down $_{i, t}$ (columns 5 and 6) exclude households with an income in time $t-1$ belonging to the 1st decile. This sample adjustment is done to account for the fact that households in the top (bottom) decile cannot experience further upward (downward) movements in the income distribution.
} 
higher tax rates lead to a higher probability of remaining in the same income decile: point estimates of $0.915 \%$ and $0.728 \%$ (standard errors of 0.26 ) for specifications of pre-tax income (column 3) and post-tax income (column 4). ${ }^{53}$

Table 16 reports the results for a sub-sample of households led by a head with completed college education. The estimated coefficient on the dummy of working spouse is still large and significant, but smaller compared to those in Table $15 .{ }^{54}$ Marginal tax rates are found to reduce the probability of moving down in the income distribution (columns 5 and 6), with point estimates of -1 and -1.3 (standard errors of 0.49 ) for the pre-tax and post-tax specifications, respectively. The effect on the probability of moving up in the income distribution, despite being positive, is not significant at usual confidence levels. For this sub-sample, higher tax rates also reduce mobility: by $1.1 \%$ when considering a distribution of post-tax income, although the point estimate of 0.5 is not significant for specifications of pre-tax income (standard errors of 0.51 in both cases).

To sum up, higher marginal tax rates increase mobility in both samples (less clearly in the case of college graduates). But the effects on upward and downward mobility are the opposite: non-college are, on average, more likely to move down in the income distribution, while college households are likely to move up (or, at least, less likely to move down) as a result of an increase in the marginal tax rates. These results, although should be taken with caution due to the increased uncertainty resulting from smaller samples, have important policy implications. Fiscal reforms that homogeneously reduce marginal tax rates seem to contribute to income mobility by making households with non-college education more likely to occupy relatively higher positions within the income distribution (and vice versa for college-graduated households).

\subsection{Do taxes increase mobility at the tails of the distribution?}

This subsection analyses how changes in taxation affect mobility at the tails of the income distribution. Particularly, I estimate the effect of changes in the marginal tax rates on the probability that households in the bottom or top deciles of income remain in that position.

As in the previous subsection, I estimate Equation 3 with different dependent variable. For households in the bottom decile of income, I construct a new dependent

\footnotetext{
${ }^{53}$ The results in the regressions in Tables 15 and 15 are robust to the inclusion of lag income as and additional control (not reported).

${ }^{54}$ This is probably the result of a higher percentage of employed wifes in the college-graduated sample ( $75 \%$ versus $68 \%$ ).
} 
(binary) variable, $u p_{i, t}$, that takes value of 1 when the household moves up to a different decile. Similarly, variable down $n_{i, t}$ takes value of 1 when a household in the top decile of income moves down in the distribution. ${ }^{55}$

Table 17 reports the estimates for households in the bottom decile (columns 1-3) and households in the top decile (4-5). The effect of an increase in the marginal tax rate on the probability that a poor households climbs to an upper position of the income distribution is negative and highly significant: point estimates range between -1.71 and -1.44 (standard errors of 0.23-0.26).

To understand the magnitude of this effect, consider a decrease of the marginal tax rate by 7 percentage points. This tax cut can explain around a quarter of the probability of leaving the bottom decile. ${ }^{56}$

The effect of tax rates on mobility in the top decile is less clear. The point estimates are negative, what would suggest that higher taxes increase the probability that households in the top decile remain in that position. However, the point estimates are associated to very high standard errors (in excess of 0.90) and therefore not significant at conventional levels.

\section{Conclusion}

Rising inequality has triggered a debate on what is the role that fiscal policy should play in addressing economic disparities. However, taxes are likely to have an impact on other features of the income distribution beyond inequality. This paper considers the effect of fiscal policy on income mobility. I exploit the variation in marginal tax rates originated by several reforms in the US to estimate how likely is that the relative position of a household in the income distribution changes when taxes vary. The resulting evidence suggest that lower marginal tax rates foster mobility along the income distribution. Particularly, an increase of one percentage point in the marginal tax rate causes a decline of around $0.8 \%$ in the probability that a household's income changes to a different decile of the income distribution. A change in the marginal tax rate of 7 percentage points accounts for around a tenth of the average likelihood of movements in the income distribution (and around a quarter of the average probability that a household in the bottom decile moves to a higher position). The mechanism that brings about this effect seems to be based on the distortions induced by taxes in the labour market decisions.

\footnotetext{
${ }^{55}$ The aggregate probability of moving away from the tails of the income distribution, i.e. $1-P^{1,1}$ and $1-P^{10,10}$ of mobility matrix $P$ in Equation 2 are shown in Figure A1.

${ }^{56}$ The average likelihood of leaving the bottom decile is $45 \%$.
} 
These empirical results have important implications for the design of fiscal policy. Tax reforms that reduce marginal rates are more likely to increase equality of opportunity (as measured by the degree of income mobility). This is because an attenuation of the distortionary effects of taxes in the labour market would make households more likely to take advantage of economic opportunities and move up in the income distribution. Therefore, fiscal policies that aim to reduce inequality should weight the trade-off in households' welfare induced by the effect on income mobility.

This analysis can be extended in several ways. First, this paper highlights the need to address the potentially different effects of taxation on income inequality and income mobility. A comprehensive analysis of fiscal policy should jointly address these issues. The interaction of a progressive tax schedule with income inequality and mobility necessitates a structural general equilibrium model that generates heterogeneity in the spirit of Aiyagari (1994) while allowing for relevant labour supply decisions. This framework would allow for a quantification of the impact of welfare of fiscal policies that address inequality, both in terms of income and wealth.

This paper has restricted its attention to mobility in the short run. Another interesting avenue is to explore the effects of taxation on social (or intergenerational) mobility. A low degree of association between parents' and children's income is an indicator of higher equality of opportunity. Nybom and Stuhler (2014) note the importance of shocks affecting the parents in determining current intergenerational mobility. It is therefore highly relevant from a policy standpoint to understand whether major fiscal reforms as Tax Revenue Act of 1986 can have a noticeable impact on children's future position in the income distribution.

Finally, my analysis can also be extended to understand the effects of taxation on other dimensions such as job mobility and the decision of becoming an entrepreneur. The macroeconomic literature that investigates the sources of wealth inequality has often relied on entrepreneurship as a key element to understand why rich households accumulate so much wealth (see De Nardi (2015)). ${ }^{57}$ Whether the incidence of personal income or corporate income taxation is a factor determining the decision to become self-employed (beyond wealth accumulation) has important policy implications.

\footnotetext{
${ }^{57}$ However, Hurst and Lusardi (2004) highlights that wealth accumulation is only an important factor on the entrepreneurial decisions for those individuals above the $95 \%$ percentile of wealth.
} 


\section{References}

Aaronson, D. and French, E. (2009). The Effects of Progressive Taxation on Labor Supply when Hours and Wages are Jointly Determined. Journal of Human Resources, 44(2):386-408.

Aghion, P., Akcigit, U., Bergeaud, A., Blundell, R., and Hémous, D. (2015). Innovation and Top Income Inequality. Working paper, Harvard University.

Aiyagari, S. R. (1994). Uninsured Idiosyncratic Risk and Aggregate Saving. Quarterly Journal of Economics, 109(3):659-684.

Arrow, K. J. and Intriligator, M. D. (2015). Introduction to the Series. In Atkinson, A. B. and Bourguignon, F., editors, Handbook of Income Distribution, volume 2 of Handbook of Income Distribution, pages xvii -lxiii. Elsevier.

Barro, R. J. and Redlick, C. J. (2011). Macroeconomic Effects from Government Purchases and Taxes. Quarterly Journal of Economics, 126(1):51-102.

Bartholomew, D. (1973). Stochastic Models for Social Processes. Wiley series in probability and mathematical statistics. J. Wiley.

Blundell, R., Duncan, A., and Meghir, C. (1998). Estimating Labor Supply Responses Using Tax Reforms. Econometrica, 66(4):827-861.

Bradbury, K. L. (2011). Trends in US Family Income Mobility, 1969-2006. Working Papers 11-10, Federal Reserve Bank of Boston.

Butrica, B. A. and Burkhauser, R. V. (1997). Estimating Federal Income Tax Burdens for Panel Study of Income Dynamics (PSID) Families Using the National Bureau of Economic Research TAXSIM Model. Syracuse University Center for Policy Research Aging Studies Program Paper, 12.

Chetty, R. and Hendren, N. (2015). The Impacts of Neighborhoods on Intergenerational Mobility: Childhood Exposure Effects and County-Level Estimates. Working paper, Harvard University.

Chetty, R., Hendren, N., Kline, P., and Saez, E. (2014a). Where is the Land of Opportunity? The Geography of Intergenerational Mobility in the United States. Working Paper 19843, National Bureau of Economic Research.

Chetty, R., Hendren, N., Kline, P., Saez, E., and Turner, N. (2014b). Is the United States Still a Land of Opportunity? Recent Trends in Intergenerational Mobility. Working Paper 19844, National Bureau of Economic Research.

Council of Economic Advisers (2015). Economic Report of the President. USA Government Printing Office, Washington.

De Nardi, M. (2015). Quantitative Models of Wealth Inequality: A Survey. Working Paper 21106, National Bureau of Economic Research. 
Diamond, P. and Saez, E. (2011). The Case for a Progressive Tax: From Basic Research to Policy Recommendations. Journal of Economic Perspectives, 25(4):165-190.

Fairlie, R. W. and Krashinsky, H. A. (2012). Liquidity Constraints, Household Wealth, and Entrepreneurship Revisited. Review of Income and Wealth, 58(2):279-306.

Feenberg, D. and Coutts, E. (1993). An Introduction to the TAXSIM Model. Journal of Policy Analysis and Management, 12(1):189-194.

Fields, G. and Ok, E. (1999). The Measurement of Income Mobility: An Introduction to the Literature. In Silber, J., editor, Handbook of Income Inequality Measurement, volume 71 of Recent Economic Thought Series, pages 557-598. Springer Netherlands.

French, E. (2005). The Effects of Health, Wealth, and Wages on Labour Supply and Retirement Behaviour. Review of Economic Studies, 72(2):395-427.

Gittleman, M. and Joyce, M. (1999). Have Family Income Mobility Patterns Changed? Demography, 36(3):299-314.

Gottschalk, P. (1997). Inequality, Income Growth, and Mobility: The Basic Facts. Journal of Economic Perspectives, 11(2):21-40.

Gruber, J. and Saez, E. (2002). The Elasticity of Taxable Income: Evidence and Implications. Journal of Public Economics, 84(1):1-32.

Hart, P. (1976). The Comparative Statics and Dynamics of Income Distributions. Journal of the Royal Statistical Society. Series A, 139(1):108-125.

Heathcote, J., Storesletten, K., and Violante, G. L. (2009). Quantitative Macroeconomics with Heterogeneous Households. Annual Review of Economics, 1(1):319-354.

Hungerford, T. L. (1993). US Income Mobility in the Seventies and Eighties. Review of Income and Wealth, 39(4):403-417.

Hurst, E. and Lusardi, A. (2004). Liquidity Constraints, Household Wealth, and Entrepreneurship. Journal of Political Economy, 112(2):319-347.

Jäntti, M. and Jenkins, S. P. (2015). Income Mobility. In Atkinson, A. B. and Bourguignon, F., editors, Handbook of Income Distribution, volume 2 of Handbook of Income Distribution, pages 807 - 935. Elsevier.

Keane, M. P. (2011). Labor Supply and Taxes: A Survey. Journal of Economic Literature, 49(4):961-1075.

Kopczuk, W., Saez, E., and Song, J. (2010). Earnings Inequality and Mobility in the United States: Evidence from Social Security Data Since 1937. Quarterly Journal of Economics, 125(1):91-128. 
Larrimore, J., Mortenson, J., Splinter, D., et al. (2015). Income and Earnings Mobility in US Tax Data. Working paper, Board of Governors of the Federal Reserve System (US).

Lerman, R. I. and Yitzhaki, S. (1995). Changing Ranks and the Inequality Impacts of Taxes and Transfers. National Tax Journal, 48(1):pp. 45-59.

Mertens, K. (2013). Marginal Tax Rates and Income: New Time Series Evidence. Working Paper 19171, National Bureau of Economic Research.

Mertens, K. and Ravn, M. O. (2011). Understanding the Aggregate Effects of Anticipated and Unanticipated Tax Policy Shocks. Review of Economic Dynamics, 14(1):27-54.

Mertens, K. and Ravn, M. O. (2012). Empirical Evidence on the Aggregate Effects of Anticipated and Unanticipated US Tax Policy Shocks. American Economic Journal: Economic Policy, 4(2):145-81.

Mertens, K. and Ravn, M. O. (2013). The Dynamic Effects of Personal and Corporate Income Tax Changes in the United States. American Economic Review, 103(4):121247.

Nybom, M. and Stuhler, J. (2014). Interpreting Trends in Intergenerational Mobility. Working paper, Universidad Carlos III.

Piketty, T. (2014). Capital in the Twenty-First Century. Harvard University Press.

Piketty, T. and Saez, E. (2003). Income Inequality in the United States, 1913-1998. Quarterly Journal of Economics, 118(1):1-41.

Piketty, T. and Saez, E. (2007). How Progressive is the US Federal Tax System? A Historical and International Perspective. Journal of Economic Perspectives, 21(1):324.

Quadrini, V. and Ríos-Rull, J.-V. (2015). Inequality in Macroeconomics. In Atkinson, A. B. and Bourguignon, F., editors, Handbook of Income Distribution, volume 2 of Handbook of Income Distribution, pages 1229 - 1302. Elsevier.

Ramey, V. (2011). Identifying Government Spending Shocks: It's All in the Timing. Quarterly Journal of Economics, 126(1):1.

Romer, C. and Romer, D. (2010). The Macroeconomic Effects of Tax Changes: Estimates Based on a New Measure of Fiscal Shocks. American Economic Review, 100(3):763-801.

Saez, E., Slemrod, J., and Giertz, S. H. (2012). The Elasticity of Taxable Income with Respect to Marginal Tax Rates: A Critical Review. Journal of Economic Literature, pages $3-50$. 
Saez, E. and Zucman, G. (2014). Wealth Inequality in the United States since 1913: Evidence from Capitalized Income Tax Data. Working Paper 20625, National Bureau of Economic Research.

Shorrocks, A. (1978a). Income Inequality and Income Mobility. Journal of Economic Theory, 19(2):376 - 393.

Shorrocks, A. F. (1978b). The Measurement of Mobility. Econometrica, 46(5):10131024.

Slemrod, J. (1996). High-Income Families and the Tax Changes of the 1980s: The Anatomy of Behavioral Response. In Feldstein, M. and Poterba, J., editors, Empirical foundations of household taxation, pages 169-192. University of Chicago Press.

Stiglitz, J. (2012). The price of inequality. Penguin UK.

Zidar, O. M. (2015). Tax Cuts For Whom? Heterogeneous Effects of Income Tax Changes on Growth and Employment. Working Paper 21035, National Bureau of Economic Research. 
Figure 1: Evolution of mobility indices (1967-1996)

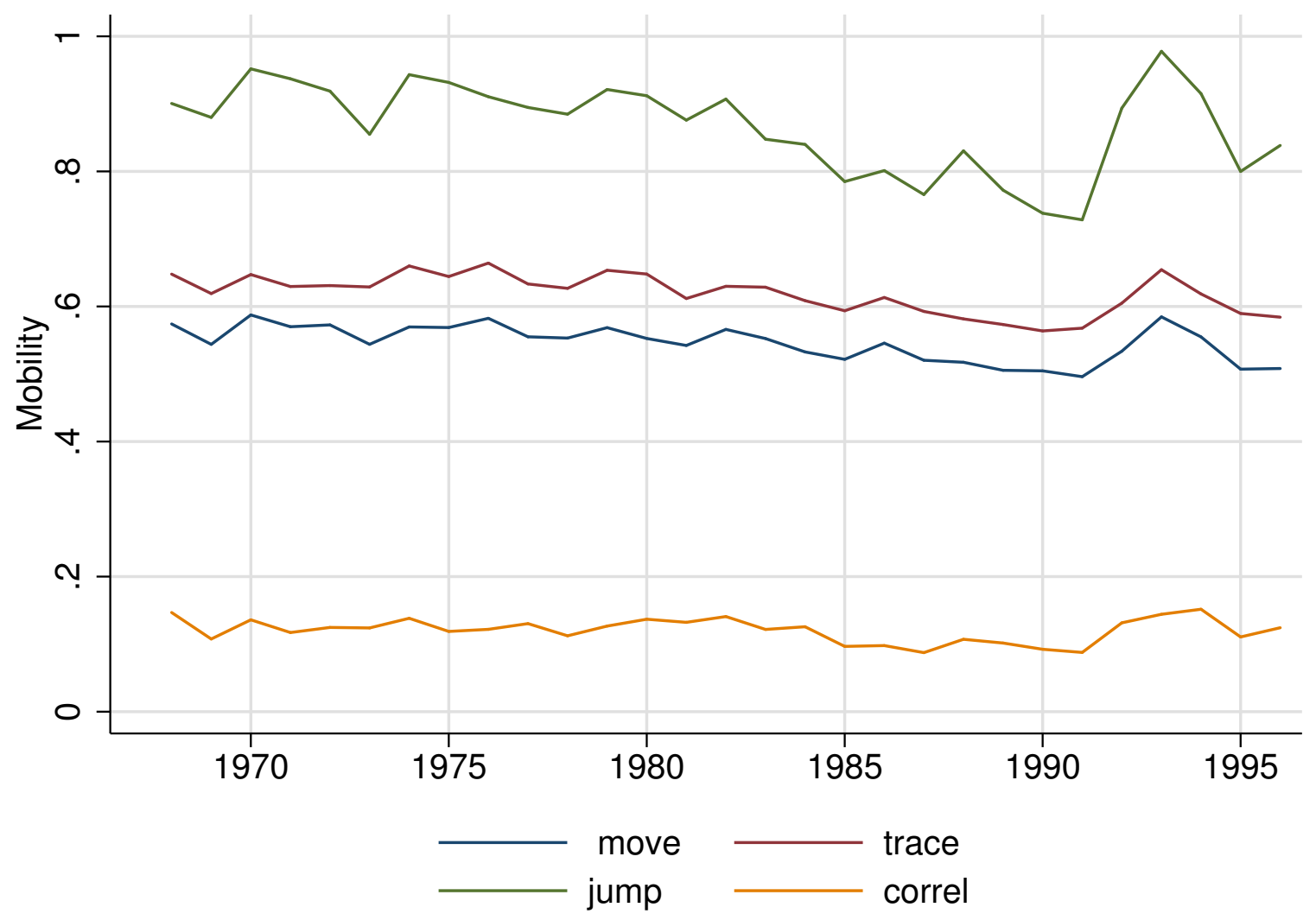

Note: Evolution of indices of mobility between 1967-1996. Blue line (move) is 1-IR, i.e. the percentage of people that change income deciles after a year. Red line (trace) is the normalised trace indicator, defined as NTI $=\frac{N-\operatorname{trace}(P)}{N-1}$. The green line (jump) represents the average number of income classes (e.g. deciles) than a household goes through after a year. The yellow line (correl) is one minus the absolute correlation of income between two adjacent years. The definition of income is Adjusted Gross Income (AGI) before taxes. The evolution is very similar when using definitions of income after taxes or after taxes and transfers. 


\section{PANEL A:}

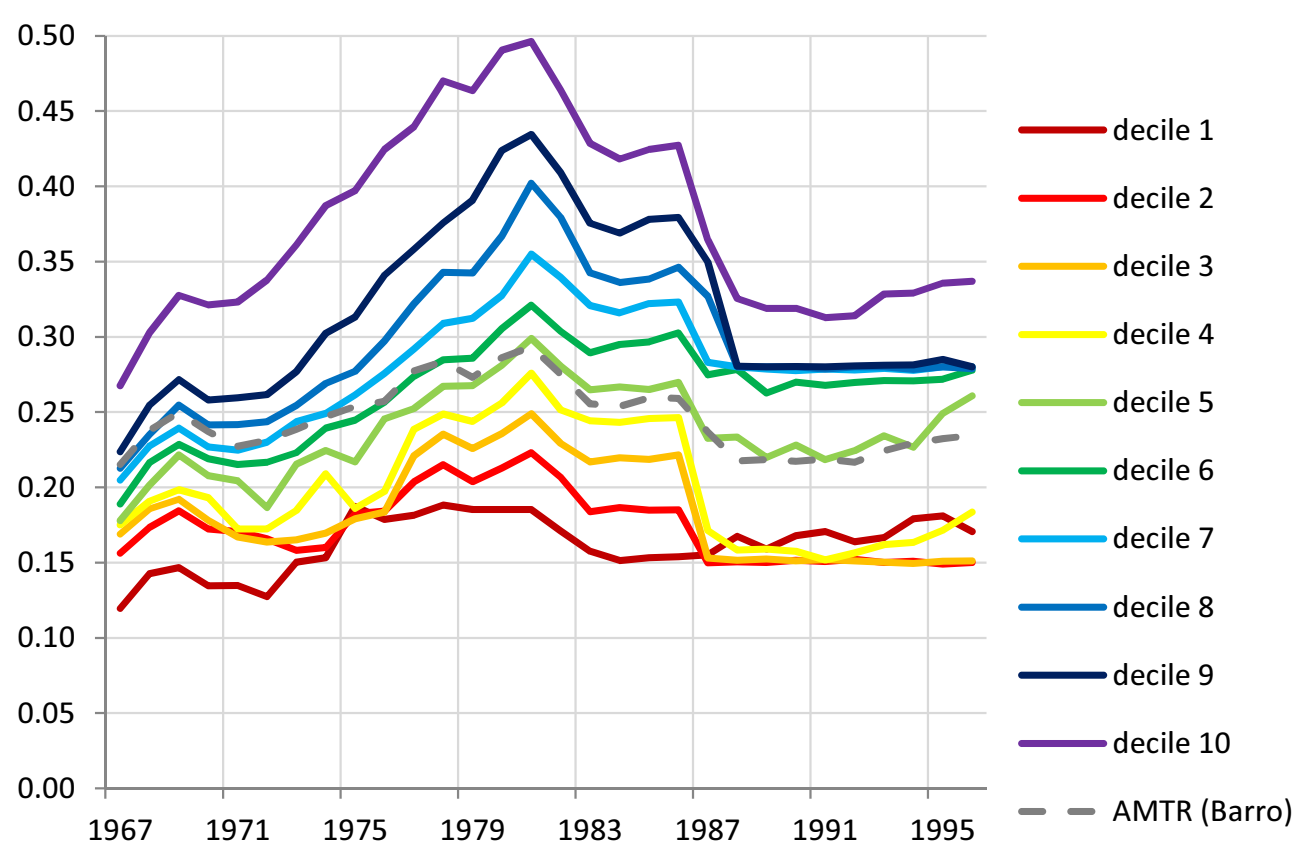

PANEL B:

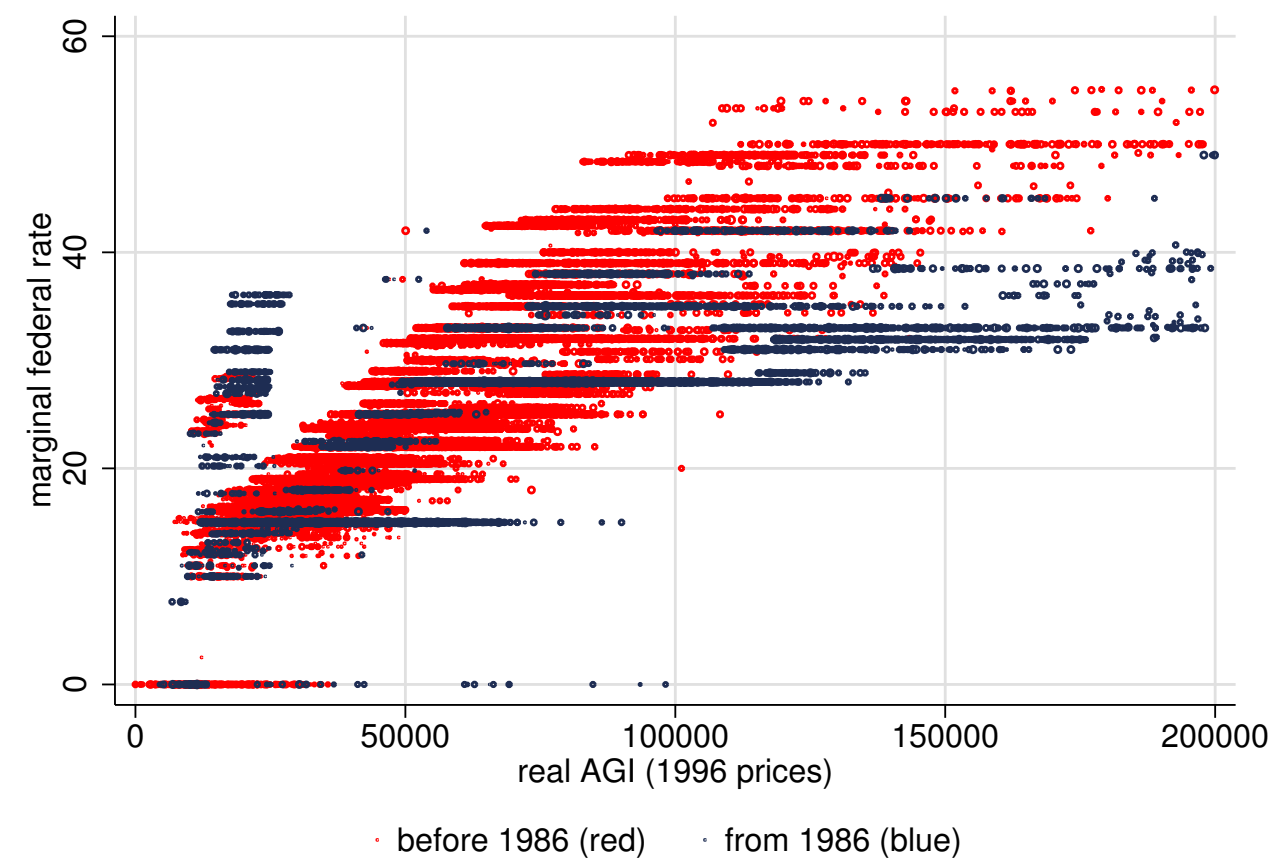

Note: Panel A shows the evolution between 1967-1996 of the average marginal tax rates for each income decile (solid lines) calculated using TAXSIM and PSID data. The dashed line is the economy-wise average marginal tax rate from Barro and Redlick (2011). Panel B shows the relationship between the federal marginal rates on individual income for each household and year in the PSID before and after the 1986 tax reform (in red and blue, respectively) and the real Adjusted Gross Income (in 1996 dollars). 
Figure 3: Relationship between taxes (R\&R, exogenous) and mobility
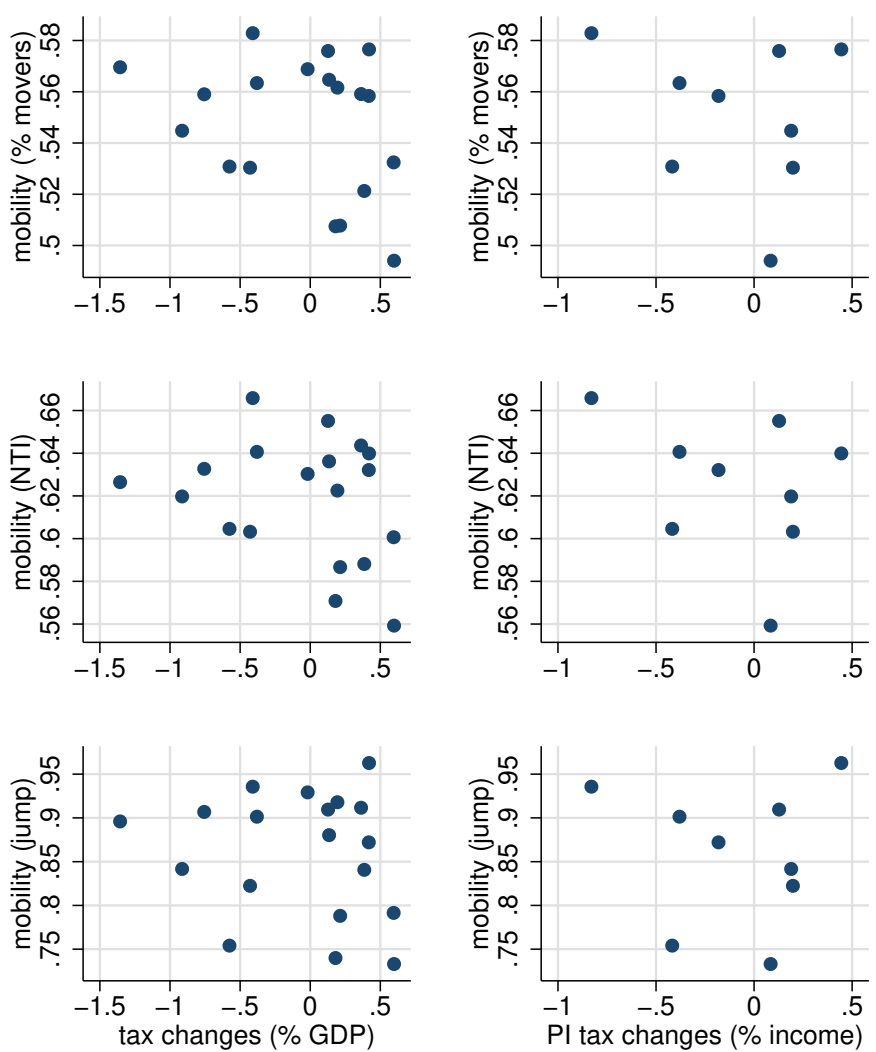

Note: Relationship between indices of mobility and tax changes. Graphs in the left column depict the correlation of mobility with the narrative measure of unanticipated exogenous legislated tax changes (as percentage of nominal GDP) from Romer and Romer (2010). Graphs in the right column use a subset of the Romer and Romer series that only considers legislated tax changes that directly affect individual income tax (as a percentage of reported income) from Mertens (2013). Mobility indices are the percentage of people changing income deciles (first row), the normalised trace index (NTI, second row) and the average number of income thresholds passed by a household between two adjacent years. 
Figure 4: The evolution of tax reforms (1967-1996)

PANEL A: Variations in the tax rate due to legislated tax changes

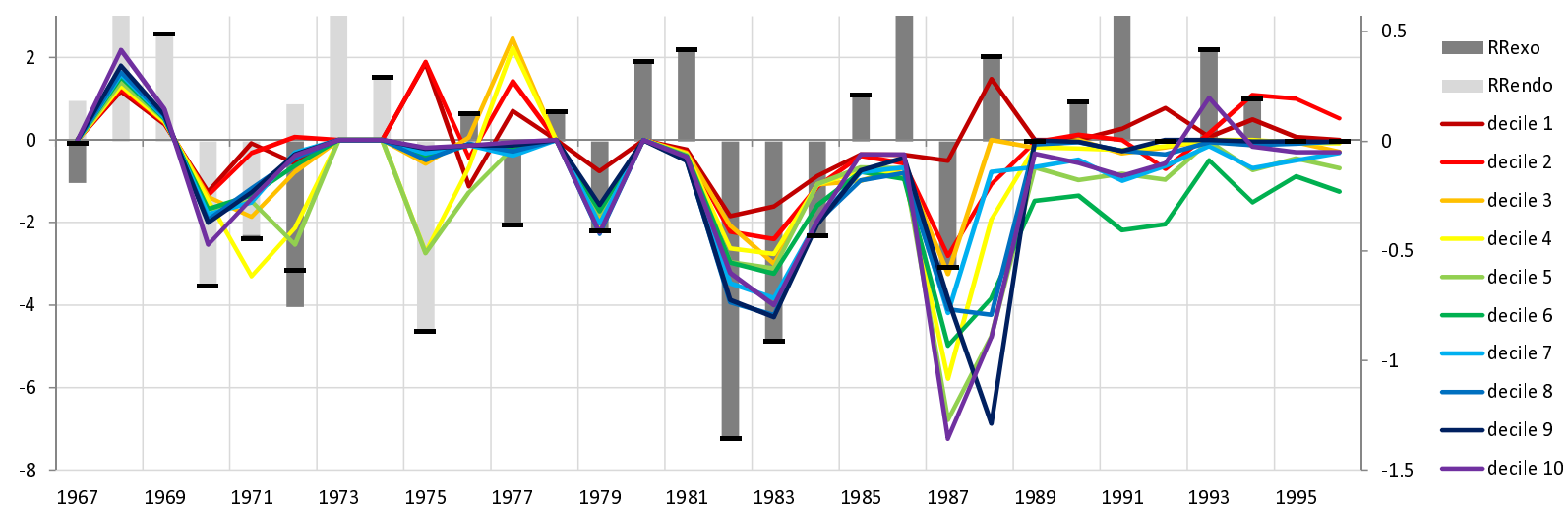

PANEL B: Percentage of households affected by tax reforms

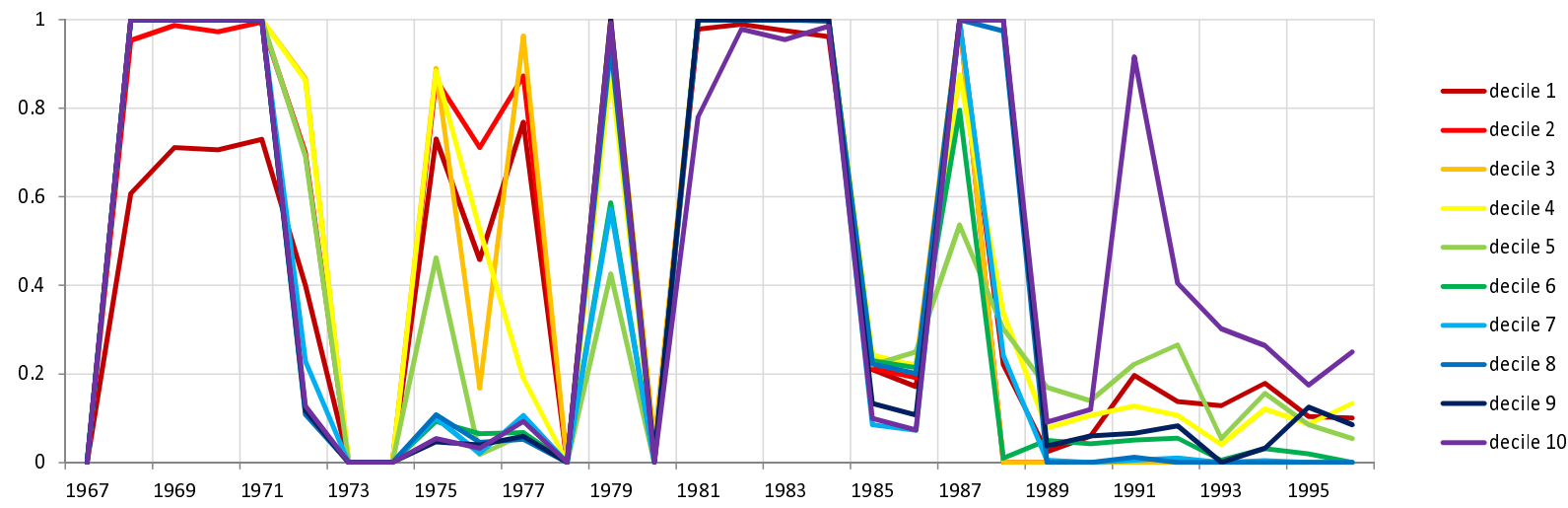

Note: Panel A shows the evolution between 1967 and 1996 of the instrument $\Delta \tau_{i, t}^{t-1}=\tau_{i, t}^{t}-\tau_{i, t}^{t-1}$ (difference between the actual marginal tax rate and a counterfactual marginal tax rate computed using TAXSIM). Grey bars represent the narrative measure of legislated tax changes (as percentage of nominal GDP) from Romer and Romer (2010). These are classified as endogenous tax changes (related to the current state of the economy, in light grey) and exogenous tax changes (unrelated to the state of economy, in dark grey). Panel B shows the (weighted) percentage of people for each decile of income that experience a change in their marginal tax rate in a given year, i.e. $\Delta \tau_{i, t}^{t-1} \neq 0$. 
Table 1: OLS estimation (with different controls)

\begin{tabular}{|c|c|c|c|c|c|}
\hline & $\begin{array}{c}(1) \\
\text { move }(\mathrm{D}) \\
\text { post-tax }\end{array}$ & $\begin{array}{c}(2) \\
\text { move }(\mathrm{D}) \\
\text { post-tax }\end{array}$ & $\begin{array}{c}(3) \\
\text { move }(\mathrm{D}) \\
\text { post-tax }\end{array}$ & $\begin{array}{c}(4) \\
\text { move }(\mathrm{D}) \\
\text { post-tax }\end{array}$ & $\begin{array}{c}(5) \\
\text { move }(\mathrm{D}) \\
\text { post-tax }\end{array}$ \\
\hline$\tau_{t}$ & $\begin{array}{c}-0.383^{* * *} \\
(0.06)\end{array}$ & $\begin{array}{c}-0.381^{* * *} \\
(0.06)\end{array}$ & $\begin{array}{c}-0.390^{* * *} \\
(0.06)\end{array}$ & $\begin{array}{c}-0.402^{* * *} \\
(0.07)\end{array}$ & $\begin{array}{c}-0.401^{* * *} \\
(0.07)\end{array}$ \\
\hline age $(H)$ & & $\begin{array}{c}-0.578^{*} \\
(0.31)\end{array}$ & $\begin{array}{c}-0.618^{* *} \\
(0.31)\end{array}$ & $\begin{array}{c}-0.620^{* *} \\
(0.31)\end{array}$ & $\begin{array}{c}-0.622^{* *} \\
(0.31)\end{array}$ \\
\hline age $(W)$ & & $\begin{array}{l}0.136 \\
(0.30)\end{array}$ & $\begin{array}{l}0.134 \\
(0.30)\end{array}$ & $\begin{array}{l}0.134 \\
(0.30)\end{array}$ & $\begin{array}{l}0.132 \\
(0.30)\end{array}$ \\
\hline family size & & & $\begin{array}{l}-0.511 \\
(0.66)\end{array}$ & $\begin{array}{c}-0.533 \\
(0.65)\end{array}$ & $\begin{array}{l}-0.535 \\
(0.65)\end{array}$ \\
\hline num children & & & $\begin{array}{l}-0.308 \\
(0.65)\end{array}$ & $\begin{array}{l}-0.268 \\
(0.65)\end{array}$ & $\begin{array}{c}-0.264 \\
(0.65)\end{array}$ \\
\hline working wife & & & & $\begin{array}{l}0.972 \\
(0.85)\end{array}$ & $\begin{array}{l}0.972 \\
(0.85)\end{array}$ \\
\hline health status & & & & & $\begin{array}{l}1.084 \\
(1.26)\end{array}$ \\
\hline$N$ & 50769 & 50748 & 50748 & 50748 & 50748 \\
\hline
\end{tabular}

Note: OLS estimates of the effects of marginal tax rates on the probability of moving to a different decile of post-tax income. Time span is 1967-1996. All regressions use panel data and include time and individual fixed effects. Robust standard errors are reported in brackets. * pvalue $p<0.1$, ** pvalue $p<0.05, * * *$ pvalue $p<0.01$. 
Table 2: OLS estimation

\begin{tabular}{|c|c|c|c|c|c|c|}
\hline & $\begin{array}{c}(1) \\
\text { move (D) } \\
\text { pre-tax }\end{array}$ & $\begin{array}{c}(2) \\
\text { move }(\mathrm{D}) \\
\text { post-tax }\end{array}$ & $\begin{array}{c}(3) \\
\text { move (D) } \\
\text { post-trans }\end{array}$ & $\begin{array}{c}(4) \\
\text { move }(\mathrm{Q}) \\
\text { pre-tax }\end{array}$ & $\begin{array}{c}(5) \\
\text { move }(\mathrm{Q}) \\
\text { post-tax }\end{array}$ & $\begin{array}{c}(6) \\
\text { move }(\mathrm{Q}) \\
\text { post-trans }\end{array}$ \\
\hline$\tau_{t}$ & $\begin{array}{c}-0.399^{* * *} \\
(0.06)\end{array}$ & $\begin{array}{c}-0.401^{* * *} \\
(0.07)\end{array}$ & $\begin{array}{c}-0.350^{* * *} \\
(0.06)\end{array}$ & $\begin{array}{c}-0.354^{* * *} \\
(0.06)\end{array}$ & $\begin{array}{c}-0.407^{* * *} \\
(0.07)\end{array}$ & $\begin{array}{c}-0.285^{* * *} \\
(0.07)\end{array}$ \\
\hline age $(H)$ & $\begin{array}{c}-0.672^{* *} \\
(0.30)\end{array}$ & $\begin{array}{c}-0.622^{* *} \\
(0.31)\end{array}$ & $\begin{array}{l}-0.257 \\
(0.31)\end{array}$ & $\begin{array}{c}-0.930^{* * *} \\
(0.31)\end{array}$ & $\begin{array}{c}-0.723^{* *} \\
(0.35)\end{array}$ & $\begin{array}{l}-0.473 \\
(0.37)\end{array}$ \\
\hline age $(W)$ & $\begin{array}{l}0.110 \\
(0.30)\end{array}$ & $\begin{array}{l}0.132 \\
(0.30)\end{array}$ & $\begin{array}{l}-0.169 \\
(0.30)\end{array}$ & $\begin{array}{l}0.503^{*} \\
(0.30)\end{array}$ & $\begin{array}{l}0.322 \\
(0.34)\end{array}$ & $\begin{array}{l}0.130 \\
(0.36)\end{array}$ \\
\hline family size & $\begin{array}{l}-0.316 \\
(0.68)\end{array}$ & $\begin{array}{l}-0.535 \\
(0.65)\end{array}$ & $\begin{array}{l}-0.826 \\
(0.65)\end{array}$ & $\begin{array}{r}-0.173 \\
(0.63)\end{array}$ & $\begin{array}{l}-0.638 \\
(0.65)\end{array}$ & $\begin{array}{l}-0.617 \\
(0.66)\end{array}$ \\
\hline num children & $\begin{array}{r}-0.163 \\
(0.68)\end{array}$ & $\begin{array}{l}-0.264 \\
(0.65)\end{array}$ & $\begin{array}{l}0.008 \\
(0.66)\end{array}$ & $\begin{array}{r}-0.589 \\
(0.63)\end{array}$ & $\begin{array}{r}-0.186 \\
(0.64)\end{array}$ & $\begin{array}{c}-0.134 \\
(0.67)\end{array}$ \\
\hline working wife & $\begin{array}{l}0.951 \\
(0.83)\end{array}$ & $\begin{array}{l}0.972 \\
(0.85)\end{array}$ & $\begin{array}{l}0.542 \\
(0.91)\end{array}$ & $\begin{array}{r}-0.242 \\
(0.83)\end{array}$ & $\begin{array}{l}0.187 \\
(0.84)\end{array}$ & $\begin{array}{r}-0.822 \\
(0.94)\end{array}$ \\
\hline health status & $\begin{array}{l}0.575 \\
(1.23)\end{array}$ & $\begin{array}{l}1.084 \\
(1.26)\end{array}$ & $\begin{array}{l}0.340 \\
(1.32) \\
\end{array}$ & $\begin{array}{l}-1.599 \\
(1.28)\end{array}$ & $\begin{array}{l}-0.093 \\
(1.28)\end{array}$ & $\begin{array}{c}-2.843^{* *} \\
(1.27) \\
\end{array}$ \\
\hline$N$ & 50748 & 50748 & 47890 & 50748 & 50748 & 47890 \\
\hline
\end{tabular}

Note: OLS estimates of the effects of marginal tax rates on the probability of moving to a different decile (D) or quintile (Q) of income. Specifications also differ on how income is measured (pre-tax AGI, post-tax AGI and post-tax and post-transfers AGI). Time span is 1967-1996. All regressions use panel data and include time and individual fixed effects. Robust standard errors are reported in brackets. $*$ pvalue $p<0.1, * *$ pvalue $p<0.05, * * *$ pvalue $p<0.01$. 
Table 3: IV estimations

\begin{tabular}{|c|c|c|c|c|c|c|}
\hline & $\begin{array}{c}(1) \\
\text { move (D) } \\
\text { pre-tax }\end{array}$ & $\begin{array}{c}(2) \\
\text { move }(\mathrm{D}) \\
\text { post-tax }\end{array}$ & $\begin{array}{c}\text { (3) } \\
\text { move }(\mathrm{D}) \\
\text { post-trans }\end{array}$ & $\begin{array}{c}(4) \\
\text { move }(\mathrm{Q}) \\
\text { pre-tax }\end{array}$ & $\begin{array}{c}(5) \\
\text { move }(\mathrm{Q}) \\
\text { post-tax } \\
\end{array}$ & $\begin{array}{c}(6) \\
\text { move }(\mathrm{Q}) \\
\text { post-trans }\end{array}$ \\
\hline$\tau_{i, t}$ & $\begin{array}{c}-0.813^{* * *} \\
(0.23)\end{array}$ & $\begin{array}{c}-0.769^{* * *} \\
(0.23)\end{array}$ & $\begin{array}{c}-0.775^{* * *} \\
(0.23)\end{array}$ & $\begin{array}{c}-0.516^{* *} \\
(0.23)\end{array}$ & $\begin{array}{c}-0.478^{* *} \\
(0.23)\end{array}$ & $\begin{array}{c}-0.506^{* *} \\
(0.23)\end{array}$ \\
\hline age $(H)$ & $\begin{array}{c}-0.582^{* *} \\
(0.27)\end{array}$ & $\begin{array}{c}-0.542^{* *} \\
(0.27)\end{array}$ & $\begin{array}{c}4.481^{* *} \\
(1.87)\end{array}$ & $\begin{array}{c}-0.895^{* * *} \\
(0.26)\end{array}$ & $\begin{array}{c}-0.708^{* * *} \\
(0.27)\end{array}$ & $\begin{array}{l}2.560 \\
(1.76)\end{array}$ \\
\hline age $(W)$ & $\begin{array}{l}0.078 \\
(0.26)\end{array}$ & $\begin{array}{l}0.104 \\
(0.26)\end{array}$ & $\begin{array}{r}-0.198 \\
(0.27)\end{array}$ & $\begin{array}{l}0.490^{*} \\
(0.25)\end{array}$ & $\begin{array}{l}0.317 \\
(0.26)\end{array}$ & $\begin{array}{l}0.114 \\
(0.26)\end{array}$ \\
\hline family size & $\begin{array}{r}-0.206 \\
(0.60)\end{array}$ & $\begin{array}{r}-0.437 \\
(0.61)\end{array}$ & $\begin{array}{r}-0.695 \\
(0.64)\end{array}$ & $\begin{array}{r}-0.130 \\
(0.58)\end{array}$ & $\begin{array}{r}-0.619 \\
(0.58)\end{array}$ & $\begin{array}{r}-0.548 \\
(0.62)\end{array}$ \\
\hline num children & $\begin{array}{c}-0.418 \\
(0.61)\end{array}$ & $\begin{array}{c}-0.490 \\
(0.62)\end{array}$ & $\begin{array}{c}-0.261 \\
(0.65)\end{array}$ & $\begin{array}{c}-0.688 \\
(0.59)\end{array}$ & $\begin{array}{c}-0.230 \\
(0.59)\end{array}$ & $\begin{array}{c}-0.274 \\
(0.62)\end{array}$ \\
\hline working wife & $\begin{array}{c}1.927^{* *} \\
(0.96)\end{array}$ & $\begin{array}{l}1.839^{*} \\
(0.97)\end{array}$ & $\begin{array}{l}1.549 \\
(0.99)\end{array}$ & $\begin{array}{l}0.140 \\
(0.95)\end{array}$ & $\begin{array}{l}0.355 \\
(0.95)\end{array}$ & $\begin{array}{r}-0.297 \\
(0.98)\end{array}$ \\
\hline health status & $\begin{array}{l}0.250 \\
(1.25)\end{array}$ & $\begin{array}{l}0.794 \\
(1.26)\end{array}$ & $\begin{array}{l}0.028 \\
(1.32)\end{array}$ & $\begin{array}{l}-1.727 \\
(1.22)\end{array}$ & $\begin{array}{c}-0.149 \\
(1.23)\end{array}$ & $\begin{array}{c}-3.006^{* *} \\
(1.28)\end{array}$ \\
\hline $1^{\text {st }}$ stage F-stat & 1577 & 1577 & 1602 & 1577 & 1577 & 1602 \\
\hline$N$ & 50745 & 50745 & 47791 & 50745 & 50745 & 47791 \\
\hline
\end{tabular}

Note: IV (2SLS) estimates of the effects of marginal tax rates on the probability of moving to a different decile (D) or quintile $(\mathrm{Q})$ of income. Tax reforms are used as an instrument for the marginal tax rate $\tau$. Specifications also differ on how income is measured (pre-tax AGI, post-tax AGI and post-tax and post-transfers AGI). Time span is 1967-1996. All regressions use panel data and include time and individual fixed effects. Robust standard errors are reported in brackets. * pvalue $p<0.1, * *$ pvalue $p<0.05, * * *$ pvalue $p<0.01$. 
Table 4: IV Estimation with average tax rate

\begin{tabular}{lcccccc}
\hline \hline & $(1)$ & $(2)$ & $(3)$ & $(4)$ & $(5)$ & $(6)$ \\
& $\begin{array}{c}\text { move }(\mathrm{D}) \\
\text { pre-tax }\end{array}$ & $\begin{array}{c}\text { move }(\mathrm{D}) \\
\text { post-tax }\end{array}$ & $\begin{array}{c}\text { move }(\mathrm{D}) \\
\text { post-trans }\end{array}$ & $\begin{array}{c}\text { move }(\mathrm{Q}) \\
\text { pre-tax }\end{array}$ & $\begin{array}{c}\text { move }(\mathrm{Q}) \\
\text { post-tax }\end{array}$ & $\begin{array}{c}\text { move }(\mathrm{Q}) \\
\text { post-trans }\end{array}$ \\
\hline$\tau_{t}$ & $-1.028^{* * *}$ & $-0.993^{* * *}$ & $-0.771^{* * *}$ & $-0.590^{* * *}$ & $-0.627^{* * *}$ & $-0.561^{* * *}$ \\
& $(0.18)$ & $(0.18)$ & $(0.16)$ & $(0.15)$ & $(0.16)$ & $(0.15)$ \\
$\bar{\tau}_{t}$ & -4.037 & -4.209 & 0.092 & -1.391 & -2.798 & -1.167 \\
& $(3.71)$ & $(3.77)$ & $(3.50)$ & $(2.98)$ & $(3.16)$ & $(3.35)$ \\
age $(H)$ & -0.077 & -0.016 & $4.462^{* *}$ & $-0.721^{*}$ & -0.358 & 2.801 \\
& $(0.51)$ & $(0.52)$ & $(2.00)$ & $(0.42)$ & $(0.45)$ & $(1.89)$ \\
age $(W)$ & -0.151 & -0.135 & -0.194 & 0.411 & 0.158 & 0.055 \\
& $(0.34)$ & $(0.34)$ & $(0.32)$ & $(0.30)$ & $(0.31)$ & $(0.31)$ \\
family size & 0.465 & 0.263 & -0.710 & 0.102 & -0.154 & -0.353 \\
& $(0.84)$ & $(0.85)$ & $(0.83)$ & $(0.73)$ & $(0.76)$ & $(0.79)$ \\
num children & -4.534 & -4.781 & -0.170 & -2.107 & -3.083 & -1.430 \\
& $(3.73)$ & $(3.79)$ & $(3.42)$ & $(2.98)$ & $(3.16)$ & $(3.27)$ \\
working wife & 10.105 & 10.365 & 1.365 & 2.959 & 6.022 & 2.048 \\
& $(7.19)$ & $(7.30)$ & $(6.67)$ & $(5.67)$ & $(6.04)$ & $(6.37)$ \\
health status & -1.860 & -1.404 & 0.074 & -2.454 & -1.611 & $-3.589^{*}$ \\
& $(2.22)$ & $(2.24)$ & $(2.08)$ & $(1.86)$ & $(1.95)$ & $(2.00)$ \\
\hline \hline st stage F-stat & 944 & 944 & 949 & 944 & 944 & 949 \\
& 50745 & 50745 & 47791 & 50745 & 50745 & 47791 \\
\hline \hline
\end{tabular}

Note: IV (2SLS) estimates of the effects of marginal and average tax rates on the probability of moving to a different decile (D) or quintile $(\mathrm{Q})$ of income. Tax reforms are used as instruments for the marginal tax rate $\tau_{t}$ and the average tax rate $\overline{\tau_{t}}$. Specifications also differ on how income is measured (pre-tax AGI and post-tax AGI and post-tax and post-transfers AGI). Time span is 1967-1996. All regressions use panel data and include time and individual fixed effects. Robust standard errors are reported in brackets. * pvalue $p<0.1, * *$ pvalue $p<0.05, * * *$ pvalue $p<0.01$. 
Table 5: Robustness to alternative definitions of income (deciles)

\begin{tabular}{|c|c|c|c|c|c|c|}
\hline & $\begin{array}{c}(1) \\
\text { tax inc. } \\
\text { (pre-tax) }\end{array}$ & $\begin{array}{c}(2) \\
\text { tax inc. } \\
\text { (post-tax) }\end{array}$ & $\begin{array}{c}(3) \\
\text { labour inc. } \\
\text { (pre-tax) }\end{array}$ & $\begin{array}{c}(4) \\
\text { labour inc. } \\
\text { (post-tax) }\end{array}$ & $\begin{array}{c}(5) \\
\text { asset inc. } \\
\text { (pre-tax) }\end{array}$ & $\begin{array}{c}(6) \\
\text { fam. inc. } \\
\text { (pre-tax) }\end{array}$ \\
\hline$\tau_{i, t t}$ & $\begin{array}{c}-0.979^{* * *} \\
(0.23)\end{array}$ & $\begin{array}{c}-0.939^{* * *} \\
(0.24)\end{array}$ & $\begin{array}{c}-1.065^{* * *} \\
(0.23)\end{array}$ & $\begin{array}{c}-0.742^{* * *} \\
(0.24)\end{array}$ & $\begin{array}{c}-0.402^{*} \\
(0.24)\end{array}$ & $\begin{array}{c}-0.473^{* *} \\
(0.23)\end{array}$ \\
\hline age (H) & $\begin{array}{c}-0.775^{* * *} \\
(0.27)\end{array}$ & $\begin{array}{c}-0.418 \\
(0.27)\end{array}$ & $\begin{array}{c}-0.684^{* * *} \\
(0.26)\end{array}$ & $\begin{array}{c}-0.640^{* *} \\
(0.27)\end{array}$ & $\begin{array}{c}-0.692^{* * *} \\
(0.27)\end{array}$ & $\begin{array}{c}1.410^{* * *} \\
(0.26)\end{array}$ \\
\hline age $(W)$ & $\begin{array}{c}0.298 \\
(0.26)\end{array}$ & $\begin{array}{c}-0.013 \\
(0.26)\end{array}$ & $\begin{array}{l}0.170 \\
(0.25)\end{array}$ & $\begin{array}{c}0.243 \\
(0.26)\end{array}$ & $\begin{array}{c}0.475^{*} \\
(0.26)\end{array}$ & $\begin{array}{c}-0.128 \\
(0.25)\end{array}$ \\
\hline family size & $\begin{array}{r}-0.756 \\
(0.61)\end{array}$ & $\begin{array}{r}-0.572 \\
(0.61)\end{array}$ & $\begin{array}{c}-0.304 \\
(0.61)\end{array}$ & $\begin{array}{c}-0.091 \\
(0.62)\end{array}$ & $\begin{array}{c}3.891^{* * *} \\
(0.61)\end{array}$ & $\begin{array}{l}0.560 \\
(0.59)\end{array}$ \\
\hline num children & $\begin{array}{c}-0.528 \\
(0.62)\end{array}$ & $\begin{array}{c}-0.492 \\
(0.62)\end{array}$ & $\begin{array}{l}-0.991 \\
(0.62)\end{array}$ & $\begin{array}{c}-1.397^{* *} \\
(0.62)\end{array}$ & $\begin{array}{c}-5.090^{* * *} \\
(0.62)\end{array}$ & $\begin{array}{c}-1.752^{* * *} \\
(0.60)\end{array}$ \\
\hline working wife & $\begin{array}{c}2.271^{* *} \\
(0.96)\end{array}$ & $\begin{array}{c}2.350^{* *} \\
(0.97)\end{array}$ & $\begin{array}{c}3.857^{* * *} \\
(0.97)\end{array}$ & $\begin{array}{c}2.944^{* * *} \\
(0.97)\end{array}$ & $\begin{array}{l}0.813 \\
(0.97)\end{array}$ & $\begin{array}{l}1.158 \\
(0.93)\end{array}$ \\
\hline health stastus & $\begin{array}{l}1.678 \\
(1.25) \\
\end{array}$ & $\begin{array}{l}0.865 \\
(1.27) \\
\end{array}$ & $\begin{array}{l}0.767 \\
(1.26) \\
\end{array}$ & $\begin{array}{l}0.644 \\
(1.27)\end{array}$ & $\begin{array}{c}3.081^{* *} \\
(1.28)\end{array}$ & $\begin{array}{c}-0.324 \\
(1.23)\end{array}$ \\
\hline $1^{\text {st }}$ stage F-stat & 1577 & 1577 & 1577 & 1577 & 1577 & 1577 \\
\hline$N$ & 50745 & 50745 & 50745 & 50745 & 50745 & 50745 \\
\hline
\end{tabular}

Note: IV (2SLS) estimates of the effects of marginal tax rates on the probability of moving to a different decile of income. Tax reforms are used as an instrument for the marginal tax rate $\tau$. Specifications differ in how income is defined: columns 1-2 refer to taxable income of head and wife, columns 3-4 refer to labour income of head and wife, column 5 refers to asset income of head and wife, and column 6 refers to adjusted family income (the adjustment consists on dividing family income by the square root of family size). Specifications also differ on how income is measured (pre-tax AGI, post-tax AGI and post-tax and post-transfers AGI). Time span is 1967-1996. All regressions use panel data and include time and individual fixed effects. Robust standard errors are reported in brackets. * pvalue $p<0.1, * *$ pvalue $p<0.05, * * *$ pvalue $p<0.01$. 
Table 6: Robustness to alternative definitions of income (quintiles)

\begin{tabular}{|c|c|c|c|c|c|c|}
\hline & $\begin{array}{c}(1) \\
\text { tax inc. } \\
\text { (pre-tax) }\end{array}$ & $\begin{array}{c}(2) \\
\text { tax inc. } \\
\text { (post-tax) }\end{array}$ & $\begin{array}{c}(3) \\
\text { labour inc. } \\
\text { (pre-tax) }\end{array}$ & $\begin{array}{c}(4) \\
\text { labour inc. } \\
\text { (post-tax) }\end{array}$ & $\begin{array}{c}(5) \\
\text { asset inc. } \\
\text { (pre-tax) }\end{array}$ & $\begin{array}{c}(6) \\
\text { fam. inc. } \\
\text { (pre-tax) }\end{array}$ \\
\hline$\tau_{t}$ & $\begin{array}{c}-0.722^{* * *} \\
(0.23)\end{array}$ & $\begin{array}{c}-0.628^{* * *} \\
(0.23)\end{array}$ & $\begin{array}{c}-1.027^{* * *} \\
(0.23)\end{array}$ & $\begin{array}{c}-0.876^{* * *} \\
(0.23)\end{array}$ & $\begin{array}{l}-0.115 \\
(0.23)\end{array}$ & $\begin{array}{l}-0.288 \\
(0.22)\end{array}$ \\
\hline age (H) & $\begin{array}{c}-0.739^{* * *} \\
(0.26)\end{array}$ & $\begin{array}{c}-0.675^{* *} \\
(0.27)\end{array}$ & $\begin{array}{c}-0.379 \\
(0.26)\end{array}$ & $\begin{array}{c}-0.534^{* *} \\
(0.26)\end{array}$ & $\begin{array}{c}-0.498^{*} \\
(0.26)\end{array}$ & $\begin{array}{c}1.092^{* * *} \\
(0.25)\end{array}$ \\
\hline age $(W)$ & $\begin{array}{l}0.358 \\
(0.25)\end{array}$ & $\begin{array}{l}0.311 \\
(0.26)\end{array}$ & $\begin{array}{l}-0.057 \\
(0.24)\end{array}$ & $\begin{array}{l}0.080 \\
(0.24)\end{array}$ & $\begin{array}{l}0.315 \\
(0.25)\end{array}$ & $\begin{array}{c}-0.017 \\
(0.23)\end{array}$ \\
\hline family size & $\begin{array}{c}-0.520 \\
(0.58)\end{array}$ & $\begin{array}{c}-0.856 \\
(0.58)\end{array}$ & $\begin{array}{c}-1.007^{*} \\
(0.58)\end{array}$ & $\begin{array}{c}-0.274 \\
(0.58)\end{array}$ & $\begin{array}{c}3.798^{* * *} \\
(0.61)\end{array}$ & $\begin{array}{l}0.107 \\
(0.55)\end{array}$ \\
\hline num children & $\begin{array}{r}-0.640 \\
(0.59)\end{array}$ & $\begin{array}{r}-0.072 \\
(0.59)\end{array}$ & $\begin{array}{l}-0.260 \\
(0.59)\end{array}$ & $\begin{array}{c}-0.983^{*} \\
(0.59)\end{array}$ & $\begin{array}{c}-5.079^{* * *} \\
(0.61)\end{array}$ & $\begin{array}{r}-0.761 \\
(0.56)\end{array}$ \\
\hline working wife & $\begin{array}{l}0.762 \\
(0.95)\end{array}$ & $\begin{array}{l}0.948 \\
(0.95)\end{array}$ & $\begin{array}{c}2.991^{* * *} \\
(0.94)\end{array}$ & $\begin{array}{c}2.589^{* * *} \\
(0.95)\end{array}$ & $\begin{array}{l}-1.385 \\
(0.95)\end{array}$ & $\begin{array}{c}-0.228 \\
(0.87)\end{array}$ \\
\hline health status & $\begin{array}{l}-0.476 \\
(1.22)\end{array}$ & $\begin{array}{l}-0.840 \\
(1.22)\end{array}$ & $\begin{array}{l}0.317 \\
(1.22)\end{array}$ & $\begin{array}{l}-0.459 \\
(1.22)\end{array}$ & $\begin{array}{l}1.796 \\
(1.24)\end{array}$ & $\begin{array}{l}-0.064 \\
(1.15)\end{array}$ \\
\hline $1^{\text {st }}$ stage F-stat & 1577 & 1577 & 1577 & 1577 & 1577 & 1577 \\
\hline$N$ & 50745 & 50745 & 50745 & 50745 & 50745 & 50745 \\
\hline
\end{tabular}

Note: IV (2SLS) estimates of the effects of marginal tax rates on the probability of moving to a different quintile of income. Tax reforms are used as an instrument for the marginal tax rate $\tau$. Specifications differ in how income is defined: columns 1-2 refer to taxable income of head and wife, columns 3-4 refer to labour income of head and wife, column 5 refers to asset income of head and wife, and column 6 refers to adjusted family income (the adjustment consists on dividing family income by the square root of family size). Specifications also differ on how income is measured (pre-tax AGI, post-tax AGI and post-tax and post-transfers AGI). Time span is 1967-1996. All regressions use panel data and include time and individual fixed effects. Robust standard errors are reported in brackets. * pvalue $p<0.1, * *$ pvalue $p<0.05, * * *$ pvalue $p<0.01$. 
Table 7: Robustness to further controls

\begin{tabular}{|c|c|c|c|c|c|c|}
\hline & $\begin{array}{c}(1) \\
\text { move }(\mathrm{D}) \\
\text { pre-tax }\end{array}$ & $\begin{array}{c}(2) \\
\text { move }(\mathrm{D}) \\
\text { post-tax }\end{array}$ & $\begin{array}{c}(3) \\
\text { move }(\mathrm{D}) \\
\text { post-trans }\end{array}$ & $\begin{array}{c}(4) \\
\text { move }(\mathrm{D}) \\
\text { pre-tax }\end{array}$ & $\begin{array}{c}(5) \\
\text { move }(\mathrm{D}) \\
\text { post-tax }\end{array}$ & $\begin{array}{c}(6) \\
\text { move }(\mathrm{D}) \\
\text { post-trans }\end{array}$ \\
\hline$\tau_{t}$ & $\begin{array}{c}-0.828^{* * *} \\
(0.23)\end{array}$ & $\begin{array}{c}-0.789^{* * *} \\
(0.24)\end{array}$ & $\begin{array}{c}-0.795^{* * *} \\
(0.23)\end{array}$ & $\begin{array}{c}-0.695^{* * *} \\
(0.23)\end{array}$ & $\begin{array}{c}-0.648^{* * *} \\
(0.23)\end{array}$ & $\begin{array}{c}-0.655^{* * *} \\
(0.23)\end{array}$ \\
\hline age (H) & $\begin{array}{r}-0.461 \\
(0.28)\end{array}$ & $\begin{array}{r}-0.436 \\
(0.28)\end{array}$ & $\begin{array}{c}4.533^{* *} \\
(1.89)\end{array}$ & $\begin{array}{c}-0.444^{*} \\
(0.26)\end{array}$ & $\begin{array}{c}-0.403 \\
(0.27)\end{array}$ & $\begin{array}{c}4.512^{* *} \\
(1.85)\end{array}$ \\
\hline age $(W)$ & $\begin{array}{l}0.114 \\
(0.27)\end{array}$ & $\begin{array}{l}0.178 \\
(0.27)\end{array}$ & $\begin{array}{r}-0.099 \\
(0.28)\end{array}$ & $\begin{array}{r}-0.022 \\
(0.25)\end{array}$ & $\begin{array}{l}0.002 \\
(0.26)\end{array}$ & $\begin{array}{r}-0.320 \\
(0.27)\end{array}$ \\
\hline family size & $\begin{array}{l}0.018 \\
(0.64)\end{array}$ & $\begin{array}{l}-0.314 \\
(0.64)\end{array}$ & $\begin{array}{l}-0.578 \\
(0.68)\end{array}$ & $\begin{array}{r}-0.305 \\
(0.60)\end{array}$ & $\begin{array}{r}-0.543 \\
(0.60)\end{array}$ & $\begin{array}{r}-0.819 \\
(0.63)\end{array}$ \\
\hline num children & $\begin{array}{l}-0.530 \\
(0.64)\end{array}$ & $\begin{array}{l}-0.473 \\
(0.65)\end{array}$ & $\begin{array}{l}-0.115 \\
(0.69)\end{array}$ & $\begin{array}{l}-0.365 \\
(0.61)\end{array}$ & $\begin{array}{l}-0.435 \\
(0.61)\end{array}$ & $\begin{array}{r}-0.207 \\
(0.64)\end{array}$ \\
\hline working wife & $\begin{array}{c}1.964^{* *} \\
(0.99)\end{array}$ & $\begin{array}{c}2.315^{* *} \\
(0.99)\end{array}$ & $\begin{array}{l}1.633 \\
(1.02)\end{array}$ & $\begin{array}{l}1.612^{*} \\
(0.93)\end{array}$ & $\begin{array}{l}1.506 \\
(0.94)\end{array}$ & $\begin{array}{l}1.131 \\
(0.96)\end{array}$ \\
\hline health status & $\begin{array}{l}0.290 \\
(1.29)\end{array}$ & $\begin{array}{l}1.232 \\
(1.29)\end{array}$ & $\begin{array}{l}0.468 \\
(1.36)\end{array}$ & $\begin{array}{l}0.116 \\
(1.24)\end{array}$ & $\begin{array}{l}0.660 \\
(1.25)\end{array}$ & $\begin{array}{r}-0.071 \\
(1.31)\end{array}$ \\
\hline wealth & $\begin{array}{c}-0.045^{* * *} \\
(0.01)\end{array}$ & $\begin{array}{c}-0.051^{* * *} \\
(0.01)\end{array}$ & $\begin{array}{c}-0.044^{* * *} \\
(0.01)\end{array}$ & & & \\
\hline decile $_{t-1}=2$ & & & & $\begin{array}{c}13.310^{* * *} \\
(1.39)\end{array}$ & $\begin{array}{c}13.321^{* * *} \\
(1.38)\end{array}$ & $\begin{array}{c}13.297^{* * *} \\
(1.40)\end{array}$ \\
\hline decile $_{t-1}=3$ & & & & $\begin{array}{c}18.715^{* * *} \\
(1.42)\end{array}$ & $\begin{array}{c}18.945^{* * *} \\
(1.42)\end{array}$ & $\begin{array}{c}17.955^{* * *} \\
(1.45)\end{array}$ \\
\hline decile $_{t-1}=4$ & & & & $\begin{array}{c}22.120^{* * *} \\
(1.38)\end{array}$ & $\begin{array}{c}22.462^{* * *} \\
(1.38)\end{array}$ & $\begin{array}{c}22.363^{* * *} \\
(1.42)\end{array}$ \\
\hline decile $_{t-1}=5$ & & & & $\begin{array}{c}22.615^{* * *} \\
(1.35)\end{array}$ & $\begin{array}{c}23.142^{* * *} \\
\quad(1.36)\end{array}$ & $\begin{array}{c}23.509^{* * *} \\
(1.40)\end{array}$ \\
\hline decile $_{t-1}=6$ & & & & $\begin{array}{c}21.808^{* * *} \\
(1.34)\end{array}$ & $\begin{array}{c}22.334^{* * *} \\
(1.34)\end{array}$ & $\begin{array}{c}20.967^{* * *} \\
(1.38)\end{array}$ \\
\hline decile $_{t-1}=7$ & & & & $\begin{array}{c}20.199^{* * *} \\
(1.35)\end{array}$ & $\begin{array}{c}20.797^{* * *} \\
(1.34)\end{array}$ & $\begin{array}{c}22.558^{* * *} \\
(1.38)\end{array}$ \\
\hline decile $_{t-1}=8$ & & & & $\begin{array}{c}17.285^{* * *} \\
(1.39)\end{array}$ & $\begin{array}{c}17.825^{* * *} \\
(1.38)\end{array}$ & $\begin{array}{c}18.513^{* * *} \\
(1.43)\end{array}$ \\
\hline decile $_{t-1}=9$ & & & & $\begin{array}{c}11.684^{* * *} \\
(1.40)\end{array}$ & $\begin{array}{c}11.852^{* * *} \\
(1.39)\end{array}$ & $\begin{array}{c}12.171^{* * *} \\
(1.44)\end{array}$ \\
\hline $1^{\text {st }}$ stage F-stat & 1570 & 1570 & 1597 & 1567 & 1567 & 1596 \\
\hline$N$ & 47508 & 47508 & 44547 & 50745 & 50745 & 47791 \\
\hline
\end{tabular}

Note: IV (2SLS) estimates of the effects of marginal tax rates on the probability of moving to a different decile of income. Tax reforms are used as an instrument for the marginal tax rate $\tau_{t}$. Specifications also differ on how income is measured (pre-tax AGI, post-tax AGI and post-tax and post-transfers AGI). Variable wealth is measured in thousands of 196 dollars. decile $e_{t-1}=k$ is a dummy variable equal to 1 if the income decile in the previous period was $k$. Time span is 1967-1996. All regressions use panel data and include time and individual fixed effects. Robust standard errors are reported in brackets. $*$ pvalue $p<0.1, * *$ pvalue $p<0.05, * * *$ pvalue $p<0.01$. 
Table 8: Robustness to income controls

\begin{tabular}{|c|c|c|c|c|c|c|}
\hline & $\begin{array}{c}(1) \\
\text { move }(\mathrm{D}) \\
\text { pre-tax }\end{array}$ & $\begin{array}{c}(2) \\
\text { move }(\mathrm{D}) \\
\text { post-tax }\end{array}$ & $\begin{array}{c}\text { (3) } \\
\text { move }(\mathrm{D}) \\
\text { post-trans }\end{array}$ & $\begin{array}{c}(4) \\
\text { move }(\mathrm{D}) \\
\text { pre-tax }\end{array}$ & $\begin{array}{c}(5) \\
\text { move }(\mathrm{D}) \\
\text { post-tax }\end{array}$ & $\begin{array}{c}(6) \\
\text { move }(\mathrm{D}) \\
\text { post-trans }\end{array}$ \\
\hline$\tau_{t}$ & $\begin{array}{c}-0.800^{* * *} \\
(0.22)\end{array}$ & $\begin{array}{c}-0.762^{* * *} \\
(0.22)\end{array}$ & $\begin{array}{c}-0.771^{* * *} \\
(0.22)\end{array}$ & $\begin{array}{c}-1.053^{* * *} \\
(0.22)\end{array}$ & $\begin{array}{c}-1.009^{* * *} \\
(0.22)\end{array}$ & $\begin{array}{c}-0.983^{* * *} \\
(0.22)\end{array}$ \\
\hline age $(H)$ & $\begin{array}{c}-0.714^{* *} \\
(0.28)\end{array}$ & $\begin{array}{c}-0.615^{* *} \\
(0.28)\end{array}$ & $\begin{array}{c}4.466^{* *} \\
(1.88)\end{array}$ & $\begin{array}{c}-0.437^{*} \\
(0.25)\end{array}$ & $\begin{array}{l}-0.397 \\
(0.25)\end{array}$ & $\begin{array}{c}3.568^{* *} \\
(1.75)\end{array}$ \\
\hline age $(W)$ & $\begin{array}{l}0.089 \\
(0.26)\end{array}$ & $\begin{array}{l}0.110 \\
(0.26)\end{array}$ & $\begin{array}{c}-0.195 \\
(0.27)\end{array}$ & $\begin{array}{l}0.039 \\
(0.24)\end{array}$ & $\begin{array}{l}0.065 \\
(0.24)\end{array}$ & $\begin{array}{r}-0.208 \\
(0.26)\end{array}$ \\
\hline family size & $\begin{array}{c}-0.253 \\
(0.60)\end{array}$ & $\begin{array}{c}-0.464 \\
(0.61)\end{array}$ & $\begin{array}{c}-0.712 \\
(0.63)\end{array}$ & $\begin{array}{l}0.046 \\
(0.57)\end{array}$ & $\begin{array}{c}-0.184 \\
(0.58)\end{array}$ & $\begin{array}{c}-0.441 \\
(0.62)\end{array}$ \\
\hline num children & $\begin{array}{l}-0.402 \\
(0.61)\end{array}$ & $\begin{array}{l}-0.481 \\
(0.62)\end{array}$ & $\begin{array}{l}-0.255 \\
(0.65)\end{array}$ & $\begin{array}{c}-0.413 \\
(0.58)\end{array}$ & $\begin{array}{r}-0.486 \\
(0.59)\end{array}$ & $\begin{array}{c}-0.274 \\
(0.63)\end{array}$ \\
\hline working wife & $\begin{array}{c}1.771^{* *} \\
(0.90)\end{array}$ & $\begin{array}{l}1.753^{*} \\
(0.90)\end{array}$ & $\begin{array}{l}1.500 \\
(0.93)\end{array}$ & $\begin{array}{c}2.940^{* * *} \\
(0.91)\end{array}$ & $\begin{array}{c}2.855^{* * *} \\
(0.91)\end{array}$ & $\begin{array}{c}2.410^{* *} \\
(0.94)\end{array}$ \\
\hline health status & $\begin{array}{l}0.321 \\
(1.24)\end{array}$ & $\begin{array}{l}0.834 \\
(1.25)\end{array}$ & $\begin{array}{l}0.048 \\
(1.32)\end{array}$ & $\begin{array}{c}-1.114 \\
(1.18)\end{array}$ & $\begin{array}{l}-0.573 \\
(1.19)\end{array}$ & $\begin{array}{l}-1.079 \\
(1.27)\end{array}$ \\
\hline $\log$ income $_{t-1}$ & $\begin{array}{l}1.649 \\
(1.66)\end{array}$ & $\begin{array}{l}0.906 \\
(1.68)\end{array}$ & $\begin{array}{l}0.552 \\
(1.69)\end{array}$ & & & \\
\hline $\operatorname{abs}\left(\Delta\right.$ income $\left._{t}\right)$ & & & & $\begin{array}{c}94.612^{* * *} \\
(2.22) \\
\end{array}$ & $\begin{array}{c}94.837^{* * *} \\
(2.22) \\
\end{array}$ & $\begin{array}{c}87.523^{* * *} \\
(2.00) \\
\end{array}$ \\
\hline $1^{\text {st }}$ stage F-stat & 1791 & 1791 & 1802 & 1581 & 1581 & 1605 \\
\hline$N$ & 50741 & 50741 & 47788 & 50736 & 50736 & 47783 \\
\hline
\end{tabular}

Note: IV (2SLS) estimates of the effects of marginal tax rates on the probability of moving to a different decile of income. Tax reforms are used as an instrument for the marginal tax rate $\tau_{t}$. Specifications also differ on how income is measured (pre-tax AGI, post-tax AGI and post-tax and post-transfers AGI). Additional controls account for lagged income and absolute income changes, where income is measured as household's AGI. Time span is 1967-1996. All regressions use panel data and include time and individual fixed effects. Robust standard errors are reported in brackets. $*$ pvalue $p<0.1$, ** pvalue $p<0.05, * * *$ pvalue $p<0.01$. 
Table 9: IV Estimation with State and Payroll Tax rates

\begin{tabular}{lcccccc}
\hline \hline & $(1)$ & $(2)$ & $(3)$ & $(4)$ & $(5)$ & $(6)$ \\
& $\begin{array}{c}\text { move }(\mathrm{D}) \\
\text { pre-tax }\end{array}$ & $\begin{array}{c}\text { move }(\mathrm{D}) \\
\text { post-tax }\end{array}$ & $\begin{array}{c}\text { move }(\mathrm{D}) \\
\text { post-trans }\end{array}$ & $\begin{array}{c}\text { move }(\mathrm{Q}) \\
\text { pre-tax }\end{array}$ & $\begin{array}{c}\text { move }(\mathrm{Q}) \\
\text { post-tax }\end{array}$ & $\begin{array}{c}\text { move }(\mathrm{Q}) \\
\text { post-trans }\end{array}$ \\
\hline$\tau_{t}$ & $-0.565^{* * *}$ & $-0.451^{* *}$ & $-0.334^{*}$ & $-0.379^{*}$ & $-0.356^{*}$ & $-0.335^{*}$ \\
& $(0.20)$ & $(0.21)$ & $(0.20)$ & $(0.19)$ & $(0.20)$ & $(0.19)$ \\
$\bar{\tau}_{t}$ & 1.820 & 5.246 & 1.777 & 0.519 & 3.168 & 1.137 \\
& $(4.19)$ & $(5.03)$ & $(4.28)$ & $(3.87)$ & $(4.32)$ & $(3.96)$ \\
age (H) & 0.079 & -0.323 & -0.313 & -0.521 & -0.097 & -0.240 \\
& $(0.43)$ & $(0.49)$ & $(0.44)$ & $(0.41)$ & $(0.45)$ & $(0.41)$ \\
age (W) & -0.678 & -0.317 & -0.101 & 0.263 & -0.324 & 0.018 \\
& $(0.42)$ & $(0.48)$ & $(0.43)$ & $(0.40)$ & $(0.45)$ & $(0.40)$ \\
family size & -1.385 & -1.997 & -2.023 & -0.726 & -1.341 & -0.940 \\
& $(1.34)$ & $(1.53)$ & $(1.35)$ & $(1.25)$ & $(1.36)$ & $(1.27)$ \\
num children & 2.093 & 5.196 & 2.366 & 0.563 & 3.253 & 1.261 \\
& $(5.06)$ & $(6.03)$ & $(5.15)$ & $(4.69)$ & $(5.20)$ & $(4.77)$ \\
& & & & & & \\
working wife & -3.635 & -11.042 & -4.178 & -1.522 & -8.103 & -3.984 \\
& $(10.10)$ & $(11.99)$ & $(10.29)$ & $(9.37)$ & $(10.37)$ & $(9.57)$ \\
& & & & & & \\
health status & 2.007 & 3.240 & 2.657 & -1.541 & 1.737 & -0.342 \\
& $(2.56)$ & $(2.91)$ & $(2.58)$ & $(2.41)$ & $(2.61)$ & $(2.45)$ \\
\hline \hline st stage F-stat & 1416 & 1416 & 1412 & 1416 & 1416 & 1412 \\
& 35408 & 35408 & 35374 & 35408 & 35408 & 35374 \\
\hline \hline
\end{tabular}

Note: IV (2SLS) estimates of the effects of marginal tax rates on the probability of moving to a different decile (D) or quintile (Q) of income. Taxes include federal income, payroll and state liabilities. Tax reforms are used as instruments for the marginal tax rate $\tau_{t}$ and the average tax rate $\overline{\tau_{t}}$. Specifications also differ on how income is measured (pre-tax AGI and post-tax AGI and post-tax and post-transfers AGI). Time span is 1967-1996. All regressions use panel data and include time and individual fixed effects. Robust standard errors are reported in brackets. * pvalue $p<0.1, * *$ pvalue $p<0.05, * * *$ pvalue $p<0.01$. 
Table 10: IV Estimation Sample Stability

\begin{tabular}{|c|c|c|c|c|c|c|}
\hline & $\begin{array}{c}(1) \\
\text { pre } 1986 \\
\text { pre-tax }\end{array}$ & $\begin{array}{c}(2) \\
\text { pre } 1986 \\
\text { post-tax }\end{array}$ & $\begin{array}{c}(3) \\
\text { pre } 1986 \\
\text { post-trans }\end{array}$ & $\begin{array}{c}(4) \\
\text { post } 1986 \\
\text { pre-tax }\end{array}$ & $\begin{array}{c}(5) \\
\text { post } 1986 \\
\text { post-tax }\end{array}$ & $\begin{array}{c}(6) \\
\text { post } 1986 \\
\text { post-trans }\end{array}$ \\
\hline$\overline{\tau_{t}}$ & $\begin{array}{c}-0.835^{* *} \\
(0.41)\end{array}$ & $\begin{array}{c}-0.971^{* * *} \\
(0.37)\end{array}$ & $\begin{array}{c}-0.847^{* *} \\
(0.35)\end{array}$ & $\begin{array}{c}-1.018^{* * *} \\
(0.26)\end{array}$ & $\begin{array}{c}-0.837^{* * *} \\
(0.27)\end{array}$ & $\begin{array}{c}-0.690^{* * *} \\
(0.26)\end{array}$ \\
\hline$\overline{\tau_{t}}$ & $\begin{array}{c}-5.145^{\text {*** }} \\
(1.76)\end{array}$ & $\begin{array}{c}-2.908^{*} \\
(1.64)\end{array}$ & $\begin{array}{r}-1.476 \\
(1.53)\end{array}$ & $\begin{array}{l}-0.959 \\
(1.91)\end{array}$ & $\begin{array}{l}-0.068 \\
(1.92)\end{array}$ & $\begin{array}{r}-0.867 \\
(1.91)\end{array}$ \\
\hline age (H) & $\begin{array}{l}1.229^{*} \\
(0.69)\end{array}$ & $\begin{array}{l}0.628 \\
(0.64)\end{array}$ & $\begin{array}{l}0.003 \\
(2.08)\end{array}$ & $\begin{array}{l}0.322 \\
(0.90)\end{array}$ & $\begin{array}{r}-1.073 \\
(0.94)\end{array}$ & $\begin{array}{r}-0.858 \\
(0.95)\end{array}$ \\
\hline age $(W)$ & $\begin{array}{c}-0.164 \\
(0.43)\end{array}$ & $\begin{array}{r}-0.005 \\
(0.42)\end{array}$ & $\begin{array}{r}-0.182 \\
(0.45)\end{array}$ & $\begin{array}{r}-0.745 \\
(0.89)\end{array}$ & $\begin{array}{l}0.760 \\
(0.92)\end{array}$ & $\begin{array}{l}0.837 \\
(0.94)\end{array}$ \\
\hline family size & $\begin{array}{r}-0.802 \\
(0.81)\end{array}$ & $\begin{array}{r}-0.340 \\
(0.80)\end{array}$ & $\begin{array}{r}-0.740 \\
(0.85)\end{array}$ & $\begin{array}{c}-1.094 \\
(1.37)\end{array}$ & $\begin{array}{c}-1.274 \\
(1.38)\end{array}$ & $\begin{array}{l}-1.062 \\
(1.35)\end{array}$ \\
\hline num children & $\begin{array}{c}-5.072^{\text {*** }} \\
(1.86)\end{array}$ & $\begin{array}{c}-3.300^{*} \\
(1.73)\end{array}$ & $\begin{array}{r}-1.710 \\
(1.58)\end{array}$ & $\begin{array}{r}-0.147 \\
(2.40)\end{array}$ & $\begin{array}{l}0.222 \\
(2.41)\end{array}$ & $\begin{array}{l}-0.342 \\
(2.38)\end{array}$ \\
\hline working wife & $\begin{array}{c}9.666^{* * *} \\
(3.11)\end{array}$ & $\begin{array}{l}5.382^{*} \\
(2.84)\end{array}$ & $\begin{array}{l}3.978 \\
(2.59)\end{array}$ & $\begin{array}{l}3.410 \\
(4.62)\end{array}$ & $\begin{array}{l}1.902 \\
(4.66)\end{array}$ & $\begin{array}{l}0.441 \\
(4.64)\end{array}$ \\
\hline health status & $\begin{array}{l}-2.792 \\
(1.97)\end{array}$ & $\begin{array}{l}-0.544 \\
(1.91)\end{array}$ & $\begin{array}{l}-2.121 \\
(1.98)\end{array}$ & $\begin{array}{l}-1.544 \\
(2.41)\end{array}$ & $\begin{array}{l}1.754 \\
(2.34)\end{array}$ & $\begin{array}{l}1.853 \\
(2.41)\end{array}$ \\
\hline $\begin{array}{l}1^{\text {st }} \text { st. F-stat } \\
N\end{array}$ & $\begin{array}{c}157 \\
29069\end{array}$ & $\begin{array}{c}157 \\
29069\end{array}$ & $\begin{array}{c}158 \\
26144\end{array}$ & $\begin{array}{c}813 \\
19356\end{array}$ & $\begin{array}{c}813 \\
19356\end{array}$ & $\begin{array}{c}810 \\
19321\end{array}$ \\
\hline
\end{tabular}

Note: IV (2SLS) estimates of the effects of marginal and average tax rates on the probability of moving to a different decile of income before and after (including) 1986. Tax reforms are used as instruments for the marginal tax rate $\tau_{t}$ and the average tax rate $\overline{\tau_{t}}$. Specifications also differ on how income is measured (pre-tax AGI and post-tax AGI and post-tax and post-transfers AGI). Time span is 19671996. All regressions use panel data and include time and individual fixed effects. Robust standard errors are reported in brackets. * pvalue $p<0.1, * *$ pvalue $p<0.05, * * *$ pvalue $p<0.01$. 


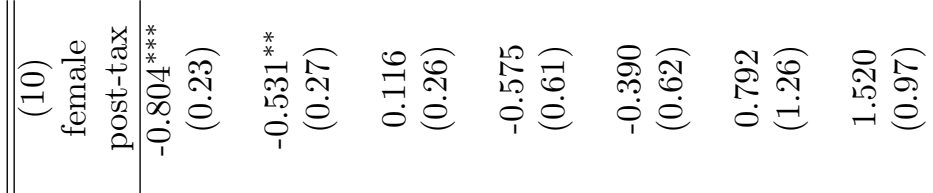

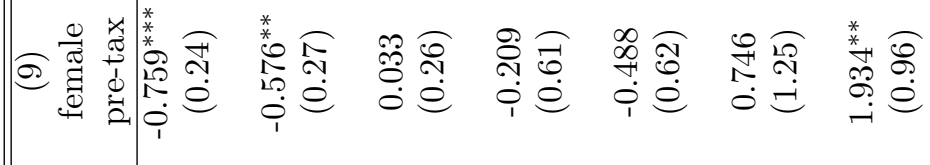

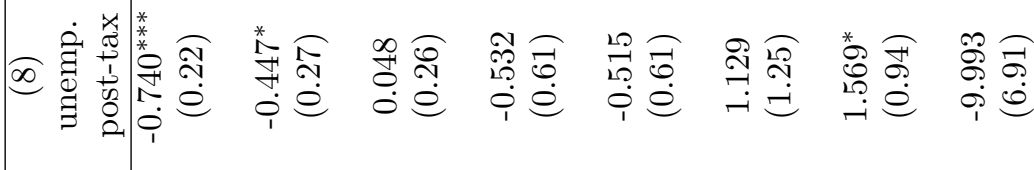

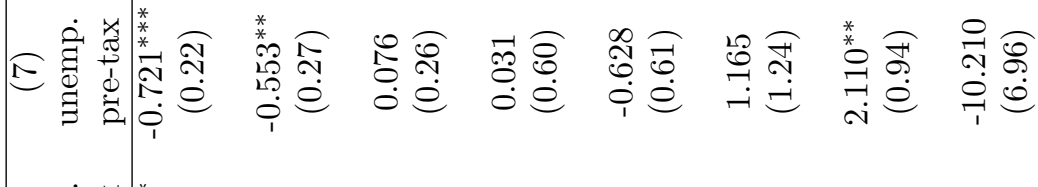

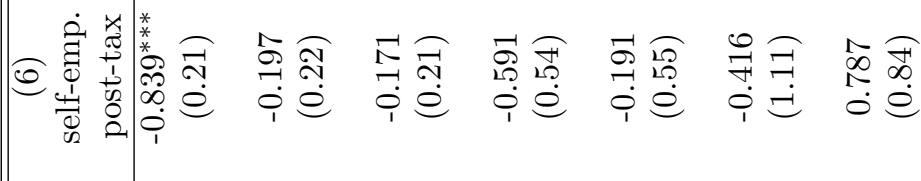

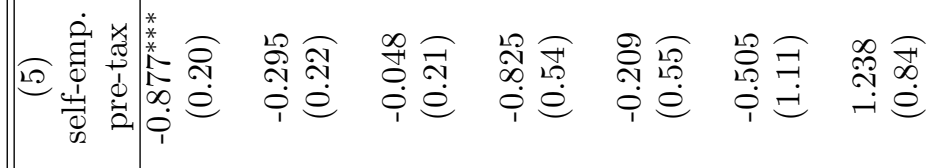

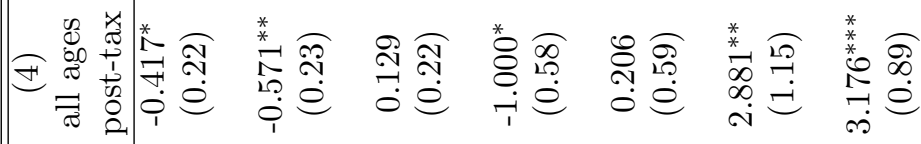

$\ddot{\exists}$

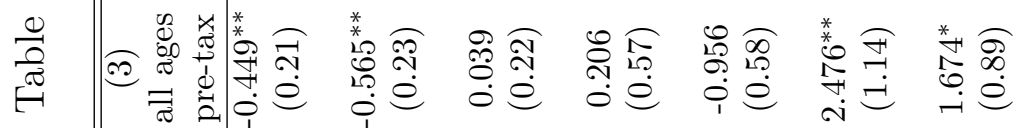

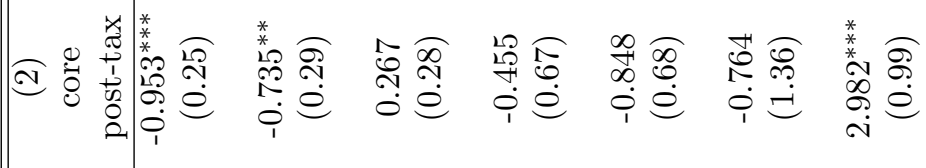

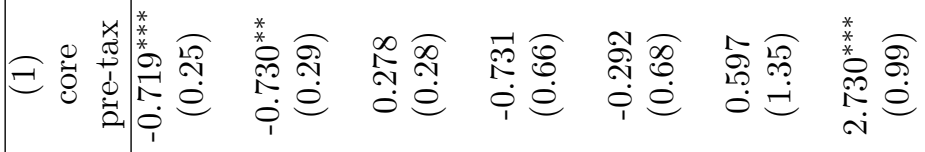

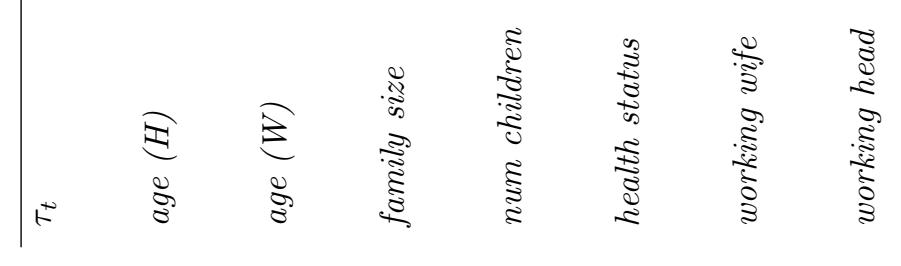

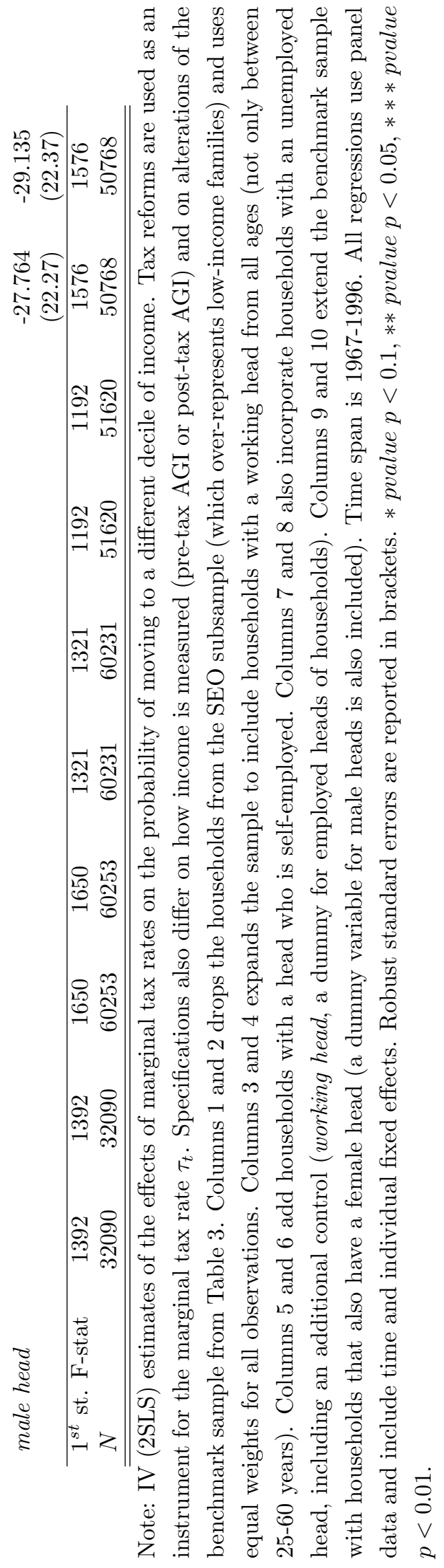


Table 12: IV Estimation Jumps with ATR

\begin{tabular}{|c|c|c|c|c|c|c|}
\hline & $\begin{array}{c}(1) \\
\text { jump (D) } \\
\text { pre-tax }\end{array}$ & $\begin{array}{c}(2) \\
\text { jump }(\mathrm{D}) \\
\text { post-tax }\end{array}$ & $\begin{array}{c}\text { (3) } \\
\text { jump (D) } \\
\text { post-trans }\end{array}$ & $\begin{array}{c}(4) \\
\text { jump }(Q) \\
\text { pre-tax }\end{array}$ & $\begin{array}{c}(5) \\
\text { jump }(Q) \\
\text { post-tax }\end{array}$ & $\begin{array}{c}\text { (6) } \\
\text { jump }(Q) \\
\text { post-trans }\end{array}$ \\
\hline$\tau_{t}$ & $\begin{array}{c}-0.013^{* * *} \\
(0.00)\end{array}$ & $\begin{array}{c}-0.012^{* * *} \\
(0.00)\end{array}$ & $\begin{array}{c}-0.008^{* *} \\
(0.00)\end{array}$ & $\begin{array}{c}-0.006^{* * *} \\
(0.00)\end{array}$ & $\begin{array}{c}-0.006^{* * *} \\
(0.00)\end{array}$ & $\begin{array}{c}-0.005^{* *} \\
(0.00)\end{array}$ \\
\hline $\bar{\tau}_{t}$ & $\begin{array}{l}-0.112 \\
(0.08)\end{array}$ & $\begin{array}{l}-0.126 \\
(0.09)\end{array}$ & $\begin{array}{l}-0.002 \\
(0.08)\end{array}$ & $\begin{array}{l}-0.045 \\
(0.04)\end{array}$ & $\begin{array}{l}-0.062 \\
(0.05)\end{array}$ & $\begin{array}{l}-0.029 \\
(0.05)\end{array}$ \\
\hline age $(H)$ & $\begin{array}{l}-0.000 \\
(0.01)\end{array}$ & $\begin{array}{l}0.002 \\
(0.01)\end{array}$ & $\begin{array}{l}0.067 \\
(0.05)\end{array}$ & $\begin{array}{l}-0.005 \\
(0.01)\end{array}$ & $\begin{array}{l}-0.000 \\
(0.01)\end{array}$ & $\begin{array}{l}0.042 \\
(0.03)\end{array}$ \\
\hline age $(W)$ & $\begin{array}{c}0.001 \\
(0.01)\end{array}$ & $\begin{array}{c}-0.001 \\
(0.01)\end{array}$ & $\begin{array}{l}0.005 \\
(0.01)\end{array}$ & $\begin{array}{l}0.004 \\
(0.00)\end{array}$ & $\begin{array}{c}0.001 \\
(0.00)\end{array}$ & $\begin{array}{c}0.001 \\
(0.00)\end{array}$ \\
\hline family size & $\begin{array}{c}0.016 \\
(0.02)\end{array}$ & $\begin{array}{l}0.014 \\
(0.02)\end{array}$ & $\begin{array}{r}-0.006 \\
(0.02)\end{array}$ & $\begin{array}{l}0.002 \\
(0.01)\end{array}$ & $\begin{array}{c}0.001 \\
(0.01)\end{array}$ & $\begin{array}{r}-0.005 \\
(0.01)\end{array}$ \\
\hline num children & $\begin{array}{c}-0.139^{*} \\
(0.08)\end{array}$ & $\begin{array}{c}-0.148^{*} \\
(0.09)\end{array}$ & $\begin{array}{r}-0.022 \\
(0.08)\end{array}$ & $\begin{array}{r}-0.055 \\
(0.04)\end{array}$ & $\begin{array}{r}-0.067 \\
(0.05)\end{array}$ & $\begin{array}{r}-0.032 \\
(0.04)\end{array}$ \\
\hline working wife & $\begin{array}{c}0.174 \\
(0.16)\end{array}$ & $\begin{array}{l}0.202 \\
(0.17)\end{array}$ & $\begin{array}{r}-0.060 \\
(0.15)\end{array}$ & $\begin{array}{l}0.068 \\
(0.08)\end{array}$ & $\begin{array}{c}0.106 \\
(0.09)\end{array}$ & $\begin{array}{c}0.024 \\
(0.09)\end{array}$ \\
\hline health status & $\begin{array}{r}-0.042 \\
(0.05)\end{array}$ & $\begin{array}{c}-0.041 \\
(0.05)\end{array}$ & $\begin{array}{r}-0.016 \\
(0.04)\end{array}$ & $\begin{array}{r}-0.037 \\
(0.03)\end{array}$ & $\begin{array}{c}-0.025 \\
(0.03)\end{array}$ & $\begin{array}{c}-0.047^{*} \\
(0.03)\end{array}$ \\
\hline $1^{\text {st }}$ stage F-stat & 944 & 944 & 948 & 944 & 944 & 948 \\
\hline$N$ & 50745 & 50745 & 47742 & 50745 & 50745 & 47742 \\
\hline
\end{tabular}

Note: IV (2SLS) estimates of the effects of marginal tax rates on the number of income ranks (in deciles, D, or quintiles, Q) crossed along the income distribution. Tax reforms are used as instruments for the marginal tax rate $\tau_{t}$ and the average tax rate $\overline{\tau_{t}}$. Specifications also differ on how income is measured (pre-tax AGI, post-tax AGI and post-tax and post-transfers AGI). Time span is 1967-1996. All regressions use panel data and include time and individual fixed effects. Robust standard errors are reported in brackets. * pvalue $p<0.1, * *$ pvalue $p<0.05, * * *$ pvalue $p<0.01$. 
Table 13: Robustness to different lags of the marginal tax rate (deciles of income)

\begin{tabular}{|c|c|c|c|c|c|c|}
\hline & $\begin{array}{c}(1) \\
\text { move }(\mathrm{D}) \\
\text { pre-tax }\end{array}$ & $\begin{array}{c}(2) \\
\text { move }(\mathrm{D}) \\
\text { post-tax }\end{array}$ & $\begin{array}{c}(3) \\
\text { move }(\mathrm{D}) \\
\text { pre-tax }\end{array}$ & $\begin{array}{c}(4) \\
\text { move }(\mathrm{D}) \\
\text { post-tax }\end{array}$ & $\begin{array}{c}(5) \\
\text { move }(\mathrm{D}) \\
\text { pre-tax }\end{array}$ & $\begin{array}{c}(6) \\
\text { move }(\mathrm{D}) \\
\text { post-tax }\end{array}$ \\
\hline$\tau_{t-1}$ & $\begin{array}{c}-0.569^{* *} \\
(0.24)\end{array}$ & $\begin{array}{c}-0.414^{*} \\
(0.24)\end{array}$ & & & & \\
\hline$\tau_{t-2}$ & & & $\begin{array}{l}0.231 \\
(0.27)\end{array}$ & $\begin{array}{l}0.484^{*} \\
(0.27)\end{array}$ & & \\
\hline$\tau_{t-3}$ & & & & & $\begin{array}{r}-0.280 \\
(0.30)\end{array}$ & $\begin{array}{r}-0.264 \\
(0.30)\end{array}$ \\
\hline age $(H)$ & $\begin{array}{c}-0.633^{* *} \\
(0.29)\end{array}$ & $\begin{array}{c}-0.652^{* *} \\
(0.29)\end{array}$ & $\begin{array}{r}-0.175 \\
(2.17)\end{array}$ & $\begin{array}{l}0.510 \\
(2.17)\end{array}$ & $\begin{array}{l}2.814 \\
(2.29)\end{array}$ & $\begin{array}{l}0.105 \\
(2.29)\end{array}$ \\
\hline age $(W)$ & $\begin{array}{l}0.229 \\
(0.28)\end{array}$ & $\begin{array}{l}0.177 \\
(0.28)\end{array}$ & $\begin{array}{l}0.613^{*} \\
(0.34)\end{array}$ & $\begin{array}{l}0.271 \\
(0.34)\end{array}$ & $\begin{array}{l}0.096 \\
(0.40)\end{array}$ & $\begin{array}{l}0.255 \\
(0.40)\end{array}$ \\
\hline family size & $\begin{array}{r}-0.657 \\
(0.61)\end{array}$ & $\begin{array}{c}-0.804 \\
(0.61)\end{array}$ & $\begin{array}{c}-0.444 \\
(0.65)\end{array}$ & $\begin{array}{r}-0.435 \\
(0.65)\end{array}$ & $\begin{array}{r}-0.876 \\
(0.69)\end{array}$ & $\begin{array}{r}-0.963 \\
(0.69)\end{array}$ \\
\hline num children & $\begin{array}{l}0.128 \\
(0.62)\end{array}$ & $\begin{array}{r}-0.066 \\
(0.62)\end{array}$ & $\begin{array}{l}0.355 \\
(0.67)\end{array}$ & $\begin{array}{l}0.061 \\
(0.67)\end{array}$ & $\begin{array}{l}0.211 \\
(0.71)\end{array}$ & $\begin{array}{r}-0.132 \\
(0.71)\end{array}$ \\
\hline working wife & $\begin{array}{l}0.900 \\
(0.84)\end{array}$ & $\begin{array}{r}-0.082 \\
(0.84)\end{array}$ & $\begin{array}{l}0.435 \\
(0.89)\end{array}$ & $\begin{array}{l}0.039 \\
(0.89)\end{array}$ & $\begin{array}{l}0.781 \\
(0.96)\end{array}$ & $\begin{array}{l}0.961 \\
(0.96)\end{array}$ \\
\hline health status & $\begin{array}{l}1.236 \\
(1.27)\end{array}$ & $\begin{array}{l}0.613 \\
(1.29)\end{array}$ & $\begin{array}{l}2.123 \\
(1.40)\end{array}$ & $\begin{array}{l}2.292 \\
(1.43)\end{array}$ & $\begin{array}{l}1.619 \\
(1.52)\end{array}$ & $\begin{array}{l}2.295 \\
(1.54)\end{array}$ \\
\hline $1^{\text {st }}$ stage F-stat & 1583 & 1583 & 1395 & 1395 & 1180 & 1180 \\
\hline$N$ & 48507 & 48507 & 41118 & 41118 & 35449 & 35449 \\
\hline
\end{tabular}

Note: IV (2SLS) estimates of the effects of marginal tax rates on the probability of moving to a different decile (D) or quintile (Q) of income. Tax reforms are used as an instrument for the marginal tax rate $\tau_{t}$. Specifications also differ on how income is measured (pre-tax AGI, post-tax AGI and post-tax and post-transfers AGI). Time span is 1967-1996. All regressions use panel data and include time and individual fixed effects. Robust standard errors are reported in brackets. $*$ pvalue $p<0.1$, ** pvalue $p<0.05, * * *$ pvalue $p<0.01$. 
Table 14: Robustness to different lags of the marginal tax rate (quintiles of income)

\begin{tabular}{|c|c|c|c|c|c|c|}
\hline & $\begin{array}{c}(1) \\
\text { move }(\mathrm{Q}) \\
\text { pre-tax }\end{array}$ & $\begin{array}{c}(2) \\
\text { move }(\mathrm{Q}) \\
\text { post-tax }\end{array}$ & $\begin{array}{c}(3) \\
\text { move }(\mathrm{Q}) \\
\text { pre-tax }\end{array}$ & $\begin{array}{c}(4) \\
\text { move }(\mathrm{Q}) \\
\text { post-tax }\end{array}$ & $\begin{array}{c}(5) \\
\text { move }(\mathrm{Q}) \\
\text { pre-tax }\end{array}$ & $\begin{array}{c}(6) \\
\text { move }(\mathrm{Q}) \\
\text { post-tax }\end{array}$ \\
\hline$\tau_{t-1}$ & $\begin{array}{c}-0.790^{* * *} \\
(0.23)\end{array}$ & $\begin{array}{c}-0.529^{* *} \\
(0.24)\end{array}$ & & & & \\
\hline$\tau_{t-2}$ & & & $\begin{array}{l}0.129 \\
(0.26)\end{array}$ & $\begin{array}{l}0.153 \\
(0.26)\end{array}$ & & \\
\hline$\tau_{t-3}$ & & & & & $\begin{array}{r}-0.270 \\
(0.28)\end{array}$ & $\begin{array}{l}-0.321 \\
(0.28)\end{array}$ \\
\hline age (H) & $\begin{array}{c}-0.744^{* * *} \\
(0.29)\end{array}$ & $\begin{array}{c}-0.594^{* *} \\
(0.29)\end{array}$ & $\begin{array}{l}1.484 \\
(2.03)\end{array}$ & $\begin{array}{l}1.687 \\
(2.02)\end{array}$ & $\begin{array}{l}2.203 \\
(2.18)\end{array}$ & $\begin{array}{l}0.395 \\
(2.16)\end{array}$ \\
\hline age $(W)$ & $\begin{array}{c}0.574^{* *} \\
(0.27)\end{array}$ & $\begin{array}{l}0.318 \\
(0.28)\end{array}$ & $\begin{array}{c}0.889^{* * *} \\
(0.33)\end{array}$ & $\begin{array}{c}0.682^{* *} \\
(0.32)\end{array}$ & $\begin{array}{l}0.249 \\
(0.37)\end{array}$ & $\begin{array}{l}0.450 \\
(0.37)\end{array}$ \\
\hline family size & $\begin{array}{l}0.149 \\
(0.59)\end{array}$ & $\begin{array}{r}-0.720 \\
(0.58)\end{array}$ & $\begin{array}{l}0.607 \\
(0.62)\end{array}$ & $\begin{array}{r}-0.130 \\
(0.62)\end{array}$ & $\begin{array}{l}0.144 \\
(0.66)\end{array}$ & $\begin{array}{c}-0.103 \\
(0.66)\end{array}$ \\
\hline num children & $\begin{array}{r}-0.956 \\
(0.60)\end{array}$ & $\begin{array}{r}-0.173 \\
(0.59)\end{array}$ & $\begin{array}{l}-0.508 \\
(0.63)\end{array}$ & $\begin{array}{l}-0.491 \\
(0.63)\end{array}$ & $\begin{array}{r}-0.462 \\
(0.67)\end{array}$ & $\begin{array}{r}-0.738 \\
(0.67)\end{array}$ \\
\hline working wife & $\begin{array}{l}-0.297 \\
(0.83)\end{array}$ & $\begin{array}{r}-0.296 \\
(0.83)\end{array}$ & $\begin{array}{c}-1.639^{*} \\
(0.87)\end{array}$ & $\begin{array}{r}-1.022 \\
(0.87)\end{array}$ & $\begin{array}{c}-1.705^{*} \\
(0.94)\end{array}$ & $\begin{array}{c}-1.194 \\
(0.94)\end{array}$ \\
\hline health status & $\begin{array}{l}-1.328 \\
(1.25)\end{array}$ & $\begin{array}{l}-1.387 \\
(1.25)\end{array}$ & $\begin{array}{l}-0.668 \\
(1.37)\end{array}$ & $\begin{array}{l}-0.971 \\
(1.36)\end{array}$ & $\begin{array}{l}0.535 \\
(1.47)\end{array}$ & $\begin{array}{l}0.722 \\
(1.47)\end{array}$ \\
\hline $1^{\text {st }}$ stage F-stat & 1583 & 1583 & 1395 & 1395 & 1180 & 1180 \\
\hline$N$ & 48507 & 48507 & 41118 & 41118 & 35449 & 35449 \\
\hline
\end{tabular}

Note: IV (2SLS) estimates of the effects of marginal tax rates on the probability of moving to a different decile (D) or quintile (Q) of income. Tax reforms are used as an instrument for the marginal tax rate $\tau_{t}$. Specifications also differ on how income is measured (pre-tax AGI, post-tax AGI and post-tax and post-transfers AGI). Time span is 1967-1996. All regressions use panel data and include time and individual fixed effects. Robust standard errors are reported in brackets. $*$ pvalue $p<0.1$, ** pvalue $p<0.05, * * *$ pvalue $p<0.01$. 
Table 15: IV estimates: households without college educations

\begin{tabular}{|c|c|c|c|c|c|c|}
\hline & $\begin{array}{c}(1) \\
\text { up } \\
\text { pre-tax }\end{array}$ & $\begin{array}{c}(2) \\
\text { up } \\
\text { post-tax }\end{array}$ & $\begin{array}{c}(3) \\
\text { stay } \\
\text { pre-tax }\end{array}$ & $\begin{array}{c}(4) \\
\text { stay } \\
\text { post-tax }\end{array}$ & $\begin{array}{c}(5) \\
\text { down } \\
\text { pre-tax }\end{array}$ & $\begin{array}{c}(6) \\
\text { down } \\
\text { post-tax }\end{array}$ \\
\hline$\tau_{t}$ & $\begin{array}{c}-1.435^{* * *} \\
(0.27)\end{array}$ & $\begin{array}{c}-1.468^{* * *} \\
(0.27)\end{array}$ & $\begin{array}{c}0.915^{* * *} \\
(0.26)\end{array}$ & $\begin{array}{c}0.728^{* * *} \\
(0.26)\end{array}$ & $\begin{array}{c}0.916^{* *} \\
(0.39)\end{array}$ & $\begin{array}{c}1.132^{* * *} \\
(0.39)\end{array}$ \\
\hline age $(H)$ & $\begin{array}{c}-0.162 \\
(0.32)\end{array}$ & $\begin{array}{l}0.059 \\
(0.33)\end{array}$ & $\begin{array}{l}0.492 \\
(0.31)\end{array}$ & $\begin{array}{l}0.315 \\
(0.32)\end{array}$ & $\begin{array}{c}-0.164 \\
(0.33)\end{array}$ & $\begin{array}{l}-0.231 \\
(0.34)\end{array}$ \\
\hline age $(W)$ & $\begin{array}{r}-0.300 \\
(0.31)\end{array}$ & $\begin{array}{r}-0.426 \\
(0.31)\end{array}$ & $\begin{array}{c}-0.114 \\
(0.30)\end{array}$ & $\begin{array}{l}-0.017 \\
(0.31)\end{array}$ & $\begin{array}{l}0.325 \\
(0.31)\end{array}$ & $\begin{array}{l}0.380 \\
(0.32)\end{array}$ \\
\hline family size & $\begin{array}{c}-0.824 \\
(0.69)\end{array}$ & $\begin{array}{c}-1.254^{*} \\
(0.70)\end{array}$ & $\begin{array}{l}0.187 \\
(0.67)\end{array}$ & $\begin{array}{l}0.369 \\
(0.68)\end{array}$ & $\begin{array}{l}0.302 \\
(0.77)\end{array}$ & $\begin{array}{l}0.665 \\
(0.78)\end{array}$ \\
\hline num children & $\begin{array}{l}0.992 \\
(0.72)\end{array}$ & $\begin{array}{c}1.616^{* *} \\
(0.73)\end{array}$ & $\begin{array}{c}-0.225 \\
(0.70)\end{array}$ & $\begin{array}{r}-0.432 \\
(0.71)\end{array}$ & $\begin{array}{l}-0.498 \\
(0.80)\end{array}$ & $\begin{array}{l}-1.032 \\
(0.81)\end{array}$ \\
\hline working wife & $\begin{array}{c}16.792^{* * *} \\
(1.09)\end{array}$ & $\begin{array}{c}16.364^{* * *} \\
(1.09)\end{array}$ & $\begin{array}{c}-2.830^{* *} \\
(1.10)\end{array}$ & $\begin{array}{c}-2.099^{*} \\
(1.10)\end{array}$ & $\begin{array}{c}-18.930^{* * *} \\
(1.44)\end{array}$ & $\begin{array}{c}-19.024^{* * *} \\
(1.44)\end{array}$ \\
\hline health status & $\begin{array}{r}-0.002 \\
(1.47)\end{array}$ & $\begin{array}{r}-0.523 \\
(1.48)\end{array}$ & $\begin{array}{r}-0.292 \\
(1.39)\end{array}$ & $\begin{array}{r}-0.942 \\
(1.39) \\
\end{array}$ & $\begin{array}{l}1.082 \\
(1.66)\end{array}$ & $\begin{array}{l}2.748 \\
(1.68) \\
\end{array}$ \\
\hline $1^{\text {st }}$ stage F-stat & 1181 & 1181 & 1181 & 1181 & 781 & 781 \\
\hline$N$ & 38417 & 38417 & 39766 & 39766 & 32229 & 32229 \\
\hline
\end{tabular}

Note: IV (2SLS) estimates of the effects of marginal tax rates on the probability of moving up to a higher income decile (columns 1 and 2), staying in the same decile (columns 3 and 4) or moving down to a lower decile (columns 5 and 6). Sample is restricted to observations where the head of the household has not completed college education. Households with income in time $t-1$ belonging to the 10th decile are excluded from specifications 1 and 2 . Households with income in time $t-1$ belonging to the 1st decile are excluded from specifications 5 and 6 . Tax reforms are used as an instrument for the marginal tax rate $\tau_{t}$. Specifications also differ on how income is measured (pre-tax AGI, post-tax AGI and post-tax and post-transfers AGI). Time span is 1967-1996. All regressions use panel data and include time and individual fixed effects. Robust standard errors are reported in brackets. $*$ pvalue $p<0.1, * *$ pvalue $p<0.05, * * *$ pvalue $p<0.01$. 
Table 16: IV estimates: households with college education

\begin{tabular}{|c|c|c|c|c|c|c|}
\hline & $\begin{array}{c}\text { (1) } \\
\text { up } \\
\text { pre-tax }\end{array}$ & $\begin{array}{c}(2) \\
\text { up } \\
\text { post-tax }\end{array}$ & $\begin{array}{c}(3) \\
\text { stay } \\
\text { pre-tax }\end{array}$ & $\begin{array}{c}(4) \\
\text { stay } \\
\text { post-tax }\end{array}$ & $\begin{array}{c}(5) \\
\text { down } \\
\text { pre-tax }\end{array}$ & $\begin{array}{c}(6) \\
\text { down } \\
\text { post-tax }\end{array}$ \\
\hline$\tau_{t}$ & $\begin{array}{l}0.438 \\
(0.54)\end{array}$ & $\begin{array}{l}0.071 \\
(0.56)\end{array}$ & $\begin{array}{l}0.480 \\
(0.51)\end{array}$ & $\begin{array}{c}1.061^{* *} \\
(0.51)\end{array}$ & $\begin{array}{c}-0.994^{* *} \\
(0.49)\end{array}$ & $\begin{array}{c}-1.302^{* * *} \\
(0.49)\end{array}$ \\
\hline $\operatorname{age}(H)$ & $\begin{array}{c}-0.084 \\
(0.77)\end{array}$ & $\begin{array}{c}-0.654 \\
(0.77)\end{array}$ & $\begin{array}{l}0.352 \\
(0.55)\end{array}$ & $\begin{array}{l}0.503 \\
(0.52)\end{array}$ & $\begin{array}{l}0.190 \\
(0.48)\end{array}$ & $\begin{array}{l}0.320 \\
(0.50)\end{array}$ \\
\hline age $(W)$ & $\begin{array}{r}-0.526 \\
(0.74)\end{array}$ & $\begin{array}{r}-0.029 \\
(0.74)\end{array}$ & $\begin{array}{l}0.308 \\
(0.52)\end{array}$ & $\begin{array}{l}0.029 \\
(0.49)\end{array}$ & $\begin{array}{l}0.029 \\
(0.46)\end{array}$ & $\begin{array}{l}0.007 \\
(0.48)\end{array}$ \\
\hline family size & $\begin{array}{l}1.377 \\
(1.75)\end{array}$ & $\begin{array}{l}0.793 \\
(1.73)\end{array}$ & $\begin{array}{l}0.038 \\
(1.39)\end{array}$ & $\begin{array}{l}0.340 \\
(1.39)\end{array}$ & $\begin{array}{r}-0.155 \\
(1.20)\end{array}$ & $\begin{array}{l}0.385 \\
(1.22)\end{array}$ \\
\hline num children & $\begin{array}{l}0.006 \\
(1.72)\end{array}$ & $\begin{array}{l}0.220 \\
(1.71)\end{array}$ & $\begin{array}{l}1.443 \\
(1.36)\end{array}$ & $\begin{array}{l}2.180 \\
(1.36)\end{array}$ & $\begin{array}{r}-1.849 \\
(1.17)\end{array}$ & $\begin{array}{c}-2.948^{* *} \\
(1.19)\end{array}$ \\
\hline working wife & $\begin{array}{c}12.092^{\text {*** }} \\
(2.11)\end{array}$ & $\begin{array}{c}13.099^{* * *} \\
(2.15)\end{array}$ & $\begin{array}{l}1.844 \\
(2.01)\end{array}$ & $\begin{array}{l}-0.323 \\
(2.03)\end{array}$ & $\begin{array}{c}-9.713^{* * *} \\
(1.86)\end{array}$ & $\begin{array}{c}-8.397^{* * *} \\
(1.88)\end{array}$ \\
\hline health status & $\begin{array}{l}-1.956 \\
(3.43)\end{array}$ & $\begin{array}{r}-1.830 \\
(3.46)\end{array}$ & $\begin{array}{l}1.129 \\
(3.02)\end{array}$ & $\begin{array}{l}0.395 \\
(3.01)\end{array}$ & $\begin{array}{l}-1.252 \\
(2.84)\end{array}$ & $\begin{array}{l}-0.691 \\
(2.74)\end{array}$ \\
\hline $1^{\text {st }}$ stage F-stat & 387 & 387 & 426 & 426 & 441 & 441 \\
\hline$N$ & 8259 & 8259 & 10556 & 10556 & 10316 & 10316 \\
\hline
\end{tabular}

Note: IV (2SLS) estimates of the effects of marginal tax rates on the probability of moving up to a higher income decile (columns 1 and 2), staying in the same decile (columns 3 and 4) or moving down to a lower decile (columns 5 and 6). Sample is restricted to observations where the head of the household has completed college education. Households with income in time $t-1$ belonging to the 10th decile are excluded from specifications 1 and 2 . Households with income in time $t-1$ belonging to the 1st decile are excluded from specifications 5 and 6.Tax reforms are used as an instrument for the marginal tax rate $\tau_{t}$. Specifications also differ on how income is measured (pre-tax AGI, post-tax AGI and post-tax and post-transfers AGI). Time span is 1967-1996. All regressions use panel data and include time and individual fixed effects. Robust standard errors are reported in brackets. $*$ pvalue $p<0.1, * *$ pvalue $p<0.05, * * *$ pvalue $p<0.01$. 
Table 17: IV estimates: households in bottom and top deciles

\begin{tabular}{lcccccc}
\hline \hline & $(1)$ & $(2)$ & $(3)$ & $(4)$ & $(5)$ & $(6)$ \\
& up & up & up & down & down & down \\
& pre-tax & post-tax & post-trans & pre-tax & post-tax & post-trans \\
\hline$\tau_{t}$ & $-1.564^{* * *}$ & $-1.719^{* * *}$ & $-1.441^{* * *}$ & -0.620 & -0.713 & -0.644 \\
& $(0.23)$ & $(0.25)$ & $(0.26)$ & $(0.94)$ & $(0.91)$ & $(0.91)$ \\
age $(H)$ & 1.237 & 1.218 & 2.850 & 0.303 & 0.764 & 2.790 \\
& $(0.81)$ & $(0.77)$ & $(4.51)$ & $(0.63)$ & $(0.66)$ & $(5.09)$ \\
age $(W)$ & -0.303 & -0.269 & 0.004 & -0.103 & -0.364 & 0.133 \\
& $(0.80)$ & $(0.76)$ & $(0.78)$ & $(0.63)$ & $(0.64)$ & $(0.60)$ \\
family size & 0.238 & -0.831 & -0.201 & -2.026 & -0.997 & -0.058 \\
& $(1.54)$ & $(1.55)$ & $(1.77)$ & $(1.52)$ & $(1.61)$ & $(1.63)$ \\
num children & 2.588 & $4.343^{* * *}$ & $4.509^{* *}$ & -0.742 & $-2.839^{*}$ & $-4.887^{* * *}$ \\
& $(1.60)$ & $(1.65)$ & $(1.95)$ & $(1.62)$ & $(1.69)$ & $(1.78)$ \\
working wife & $22.714^{* * *}$ & $22.091^{* * *}$ & $20.406^{* * *}$ & $-16.340^{* * *}$ & $-17.331^{* * *}$ & $-17.583^{* * *}$ \\
& $(1.90)$ & $(1.92)$ & $(2.02)$ & $(3.78)$ & $(3.65)$ & $(3.96)$ \\
& & & & & & \\
health status & -1.449 & -0.469 & 1.695 & $8.676^{* *}$ & $10.286^{* *}$ & $7.548^{*}$ \\
& $(2.89)$ & $(3.01)$ & $(3.26)$ & $(3.91)$ & $(4.46)$ & $(4.58)$ \\
\hline $1^{\text {st }}$ stage F-stat & 456 & 439 & 438 & 90 & 91 & 73 \\
$N$ & 6961 & 6830 & 6313 & 3330 & 3379 & 3170 \\
\hline \hline
\end{tabular}

Note: IV (2SLS) estimates of the effects of marginal tax rates on the probability of moving up to a higher income decile for households in the bottom decile (columns 1-3) or the probability of moving to a lower decile for households in the top decile (columns 4-6). Tax reforms are used as an instrument for the marginal tax rate $\tau_{t}$. Specifications also differ on how income is measured (pre-tax AGI, post-tax AGI and post-tax and post-transfers AGI). Time span is 1967-1996. All regressions use panel data and include time and individual fixed effects. Robust standard errors are reported in brackets. * pvalue $p<0.1, * *$ pvalue $p<0.05, * * *$ pvalue $p<0.01$. 


\section{Appendix}

Figure A1: Evolution of the probability of transition matrix (1967-1996)

PANEL A: Bottom decile

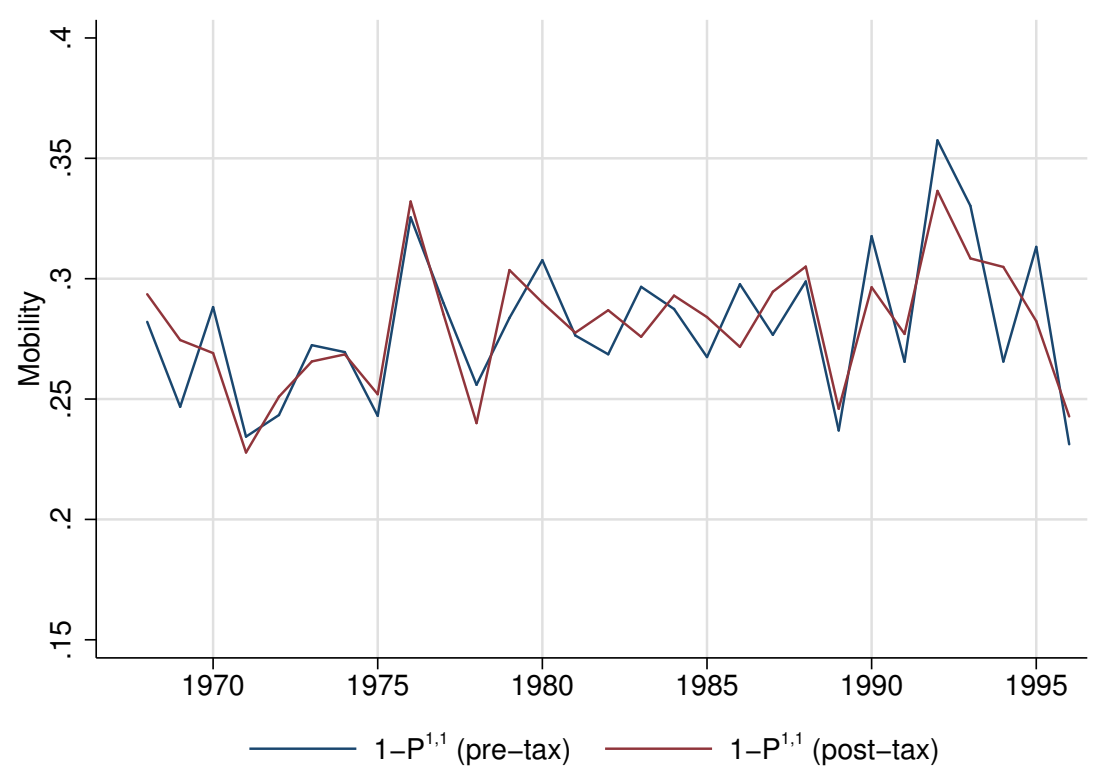

PANEL B: Top decile

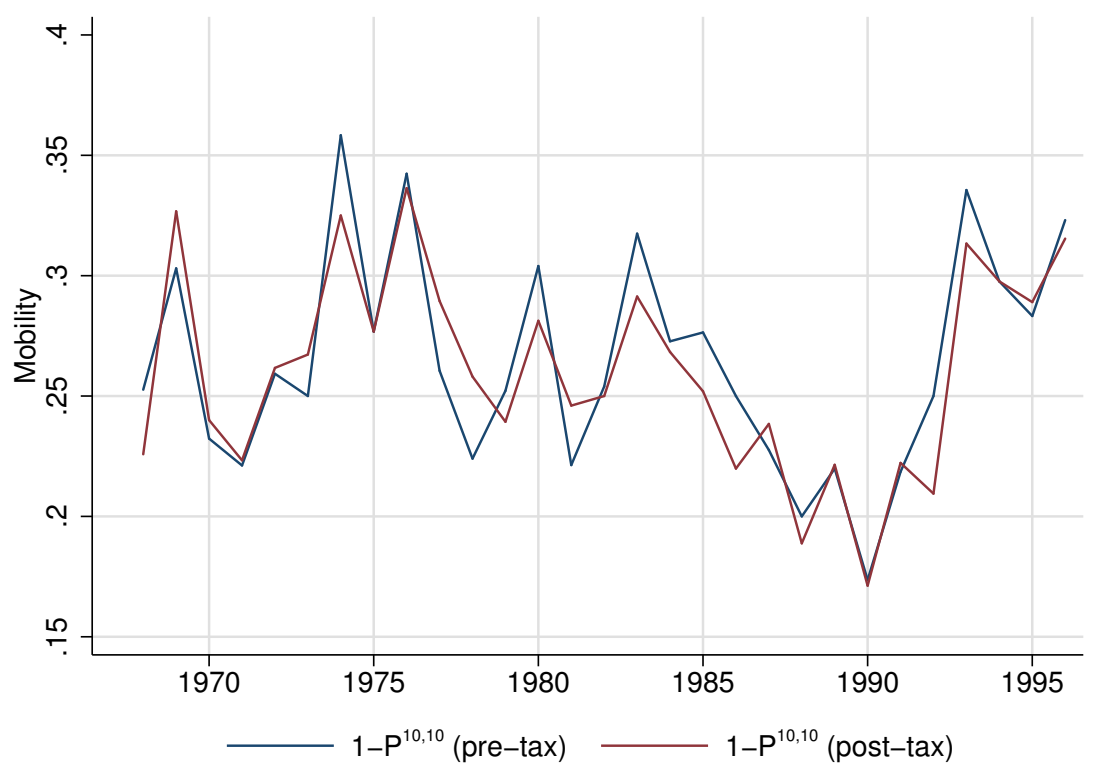

Note: Evolution of indices of mobility at the bottom and top deciles between 1967-1968. Panel A shows the evolution of the probability that a households leave the first decile of income (i.e. $1-P^{1,1}$ in Equation 2). Panel B shows the evolution of the probability that a households moves down from the top decile of income (i.e. $1-P^{10,10}$ in Equation 2). The distribution is computed using both pre-tax and post-tax income. 
Figure A2: Variation in Average Tax Rates (1967-1996)

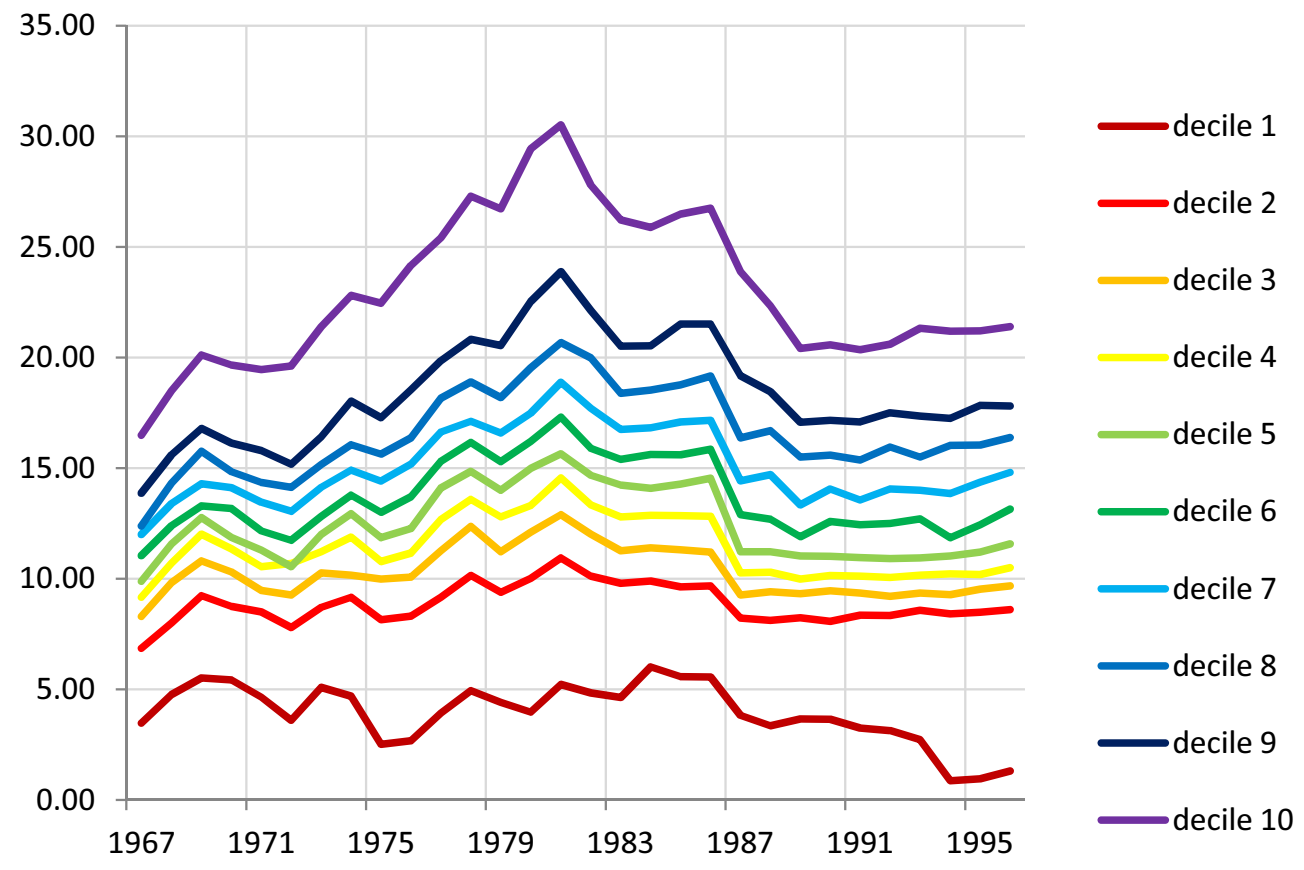

Note: Evolution of the average tax rates between 1967-1968. The figure displays the average ratio of total federal income tax liabilities to adjusted gross income (AGI) for each income decile. Tax liabilities are computed using TAXSIM and data from PSID. 
Figure A3: Variations in Average Tax Rates due to legislated tax changes (1967-1996)

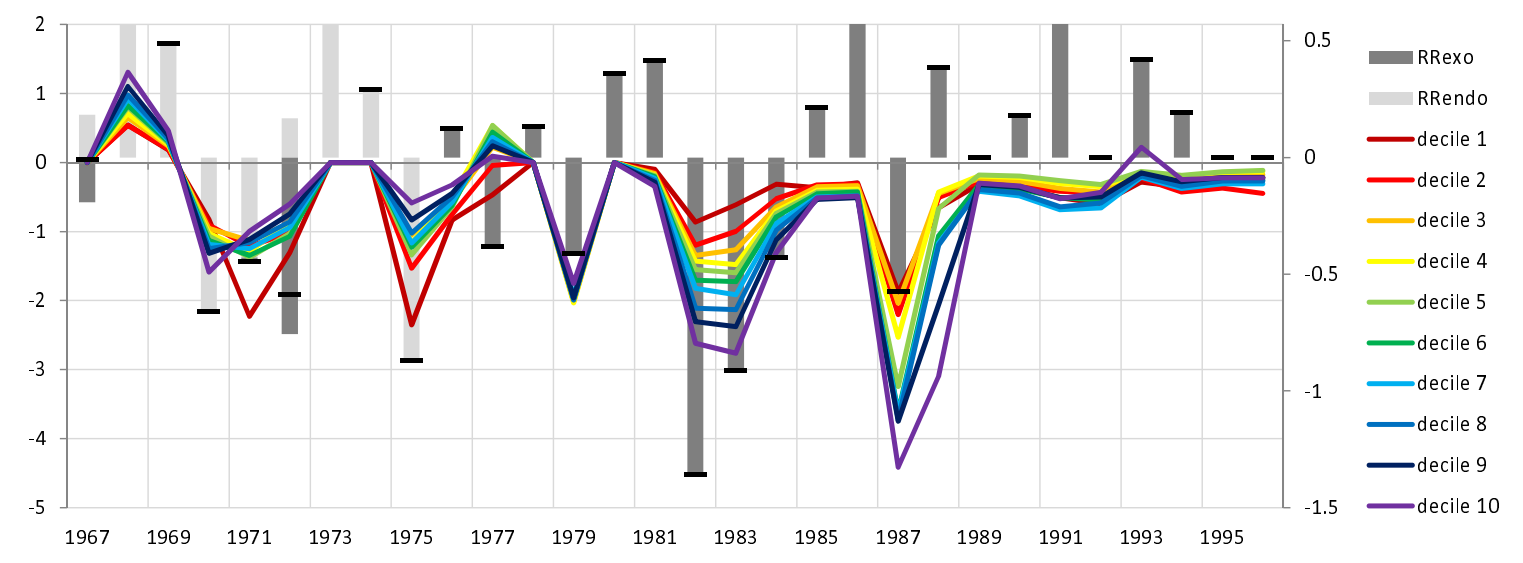

Note: Evolution between 1967 and 1996 of the instrument $\Delta \tau_{i, t}^{t-1}=\tau_{i, t}^{t}-\tau_{i, t}^{t-1}$ (difference between the actual average tax rate and a counterfactual average tax rate computed using TAXSIM). Grey bars represent the narrative measure of legislated tax changes (as percentage of nominal GDP) from Romer and Romer (2010). These are classified as endogenous tax changes (related to the current state of the economy, in light grey) and exogenous tax changes (unrelated to the state of economy, in dark grey). 
Figure A4: Variation in total marginal tax rates (1977-1996)

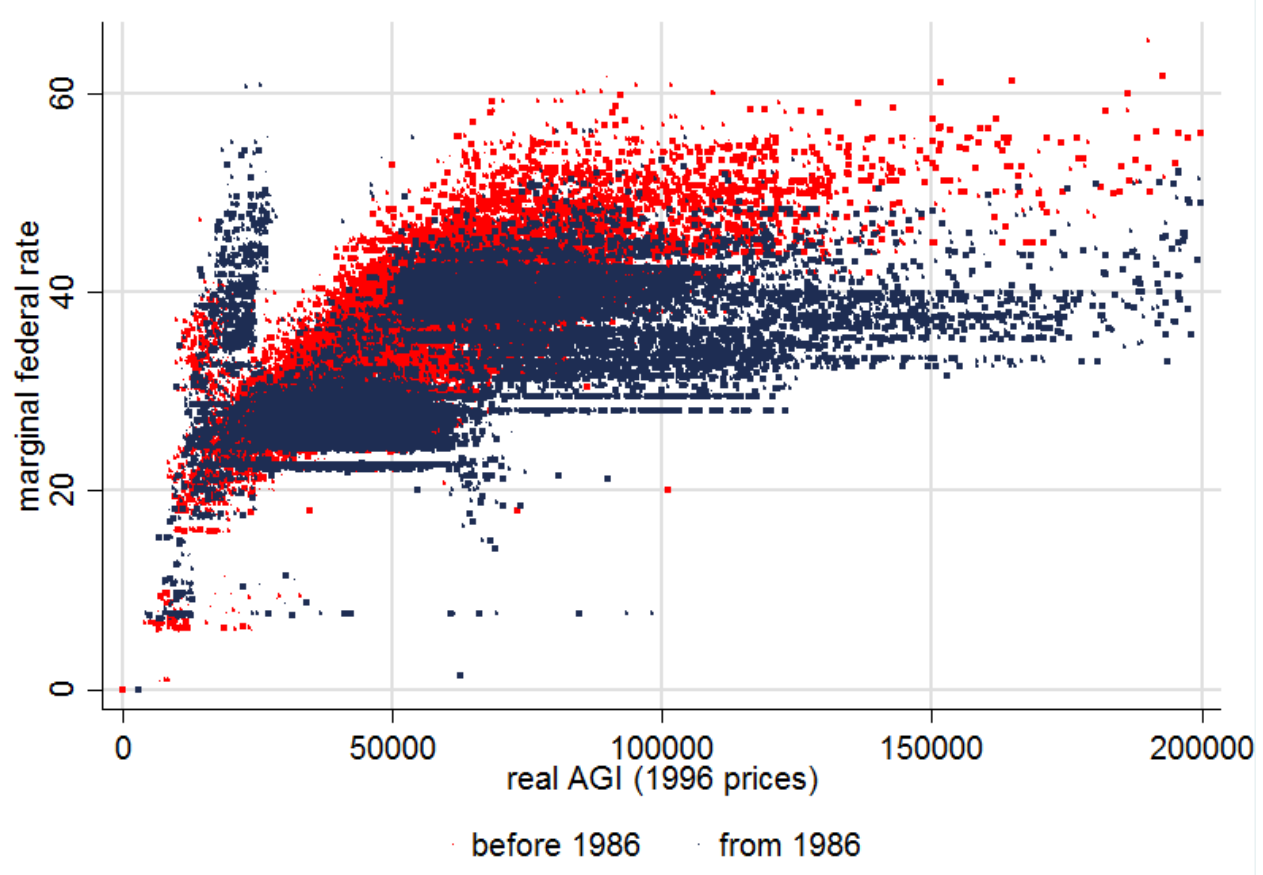

Note: Relationship between total marginal tax rates and real Adjusted Gross Income (1996 US dollars). Total marginal tax rates include the federal marginal rates on individual income, payroll and Social Security liabilities and State marginal tax rates for each household and year in the PSID before and after the 1986 tax reform (in red and blue, respectively). 
Table A1: Correlations between taxes (R\&R, total) and mobility

\begin{tabular}{lc}
\hline \hline & $\tau^{\text {Romer }}$ \\
\hline move (P) pre-tax & -0.192 \\
move (P) post-tax & -0.303 \\
move (Q) pre-tax & -0.199 \\
move (Q) post-tax & -0.263 \\
trace (P) pre-tax & -0.112 \\
trace (P) post-tax & -0.169 \\
trace (Q) pre-tax & -0.173 \\
trace (Q) pre-tax & -0.216 \\
jump (pre-tax) & -0.206 \\
jump (post-tax) & -0.225 \\
\hline \hline
\end{tabular}

Note: Correlation between indices of mobility and the narrative measure of total legislated tax changes (as percentage of nominal GDP) from Romer and Romer (2010). Mobility indices are the percentage of people changing income deciles (rows 1-2) or quintiles (rows 3-4), the normalised trace index (NTI, rows 5-6 for deciles and 7-8 for quintiles) and the average number of income deciles passed by a household between two adjacent years. The mobility indices are computed using both income before taxes (pre-tax) and after taxes (post-tax). 